Prepared in cooperation with

Department of the Navy,

Naval Facilities Engineering Command, Northwest

\title{
Biodegradation of Chloroethene Compounds in Groundwater at Operable Unit 1, Naval Undersea Warfare Center, Division Keyport, Washington, 1999-2010
}

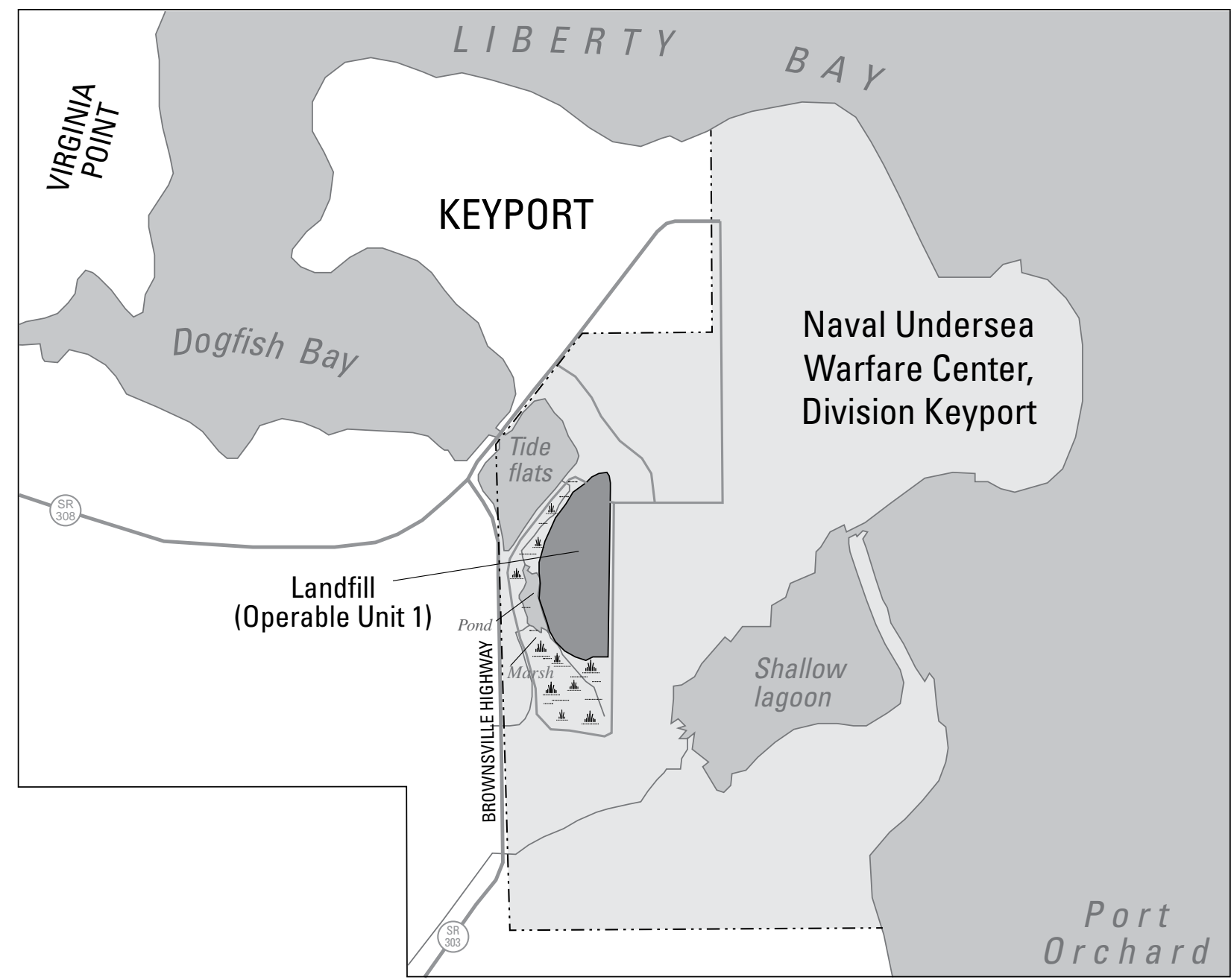

Scientific Investigations Report 2012-5013 



\section{Biodegradation of Chloroethene Compounds in Groundwater at Operable Unit 1, Naval Undersea Warfare Center, Division Keyport, Washington, 1999-2010}

By R.S. Dinicola and R.L. Huffman

Prepared in cooperation with

Department of the Navy, Naval Facilities Engineering Command, Northwest

Scientific Investigations Report 2012-5013 


\title{
U.S. Department of the Interior \\ KEN SALAZAR, Secretary \\ U.S. Geological Survey \\ Marcia K. McNutt, Director
}

\author{
U.S. Geological Survey, Reston, Virginia: 2012
}

For more information on the USGS - the Federal source for science about the Earth, its natural and living resources, natural hazards, and the environment, visit http://www.usgs.gov or call 1-888-ASK-USGS.

For an overview of USGS information products, including maps, imagery, and publications, visit http://www.usgs.gov/pubprod

To order this and other USGS information products, visit http://store.usgs.gov

Any use of trade, product, or firm names is for descriptive purposes only and does not imply endorsement by the U.S. Government.

Although this report is in the public domain, permission must be secured from the individual copyright owners to reproduce any copyrighted materials contained within this report.

Suggested citation:

Dinicola, R.S., and Huffman, R.L., 2012, Biodegradation of chloroethene compounds in groundwater at Operable Unit 1, Naval Undersea Warfare Center, Division Keyport, Washington, 1999-2010: U.S. Geological Survey Scientific Investigations Report 2012-5013, 56 p. 


\section{Contents}

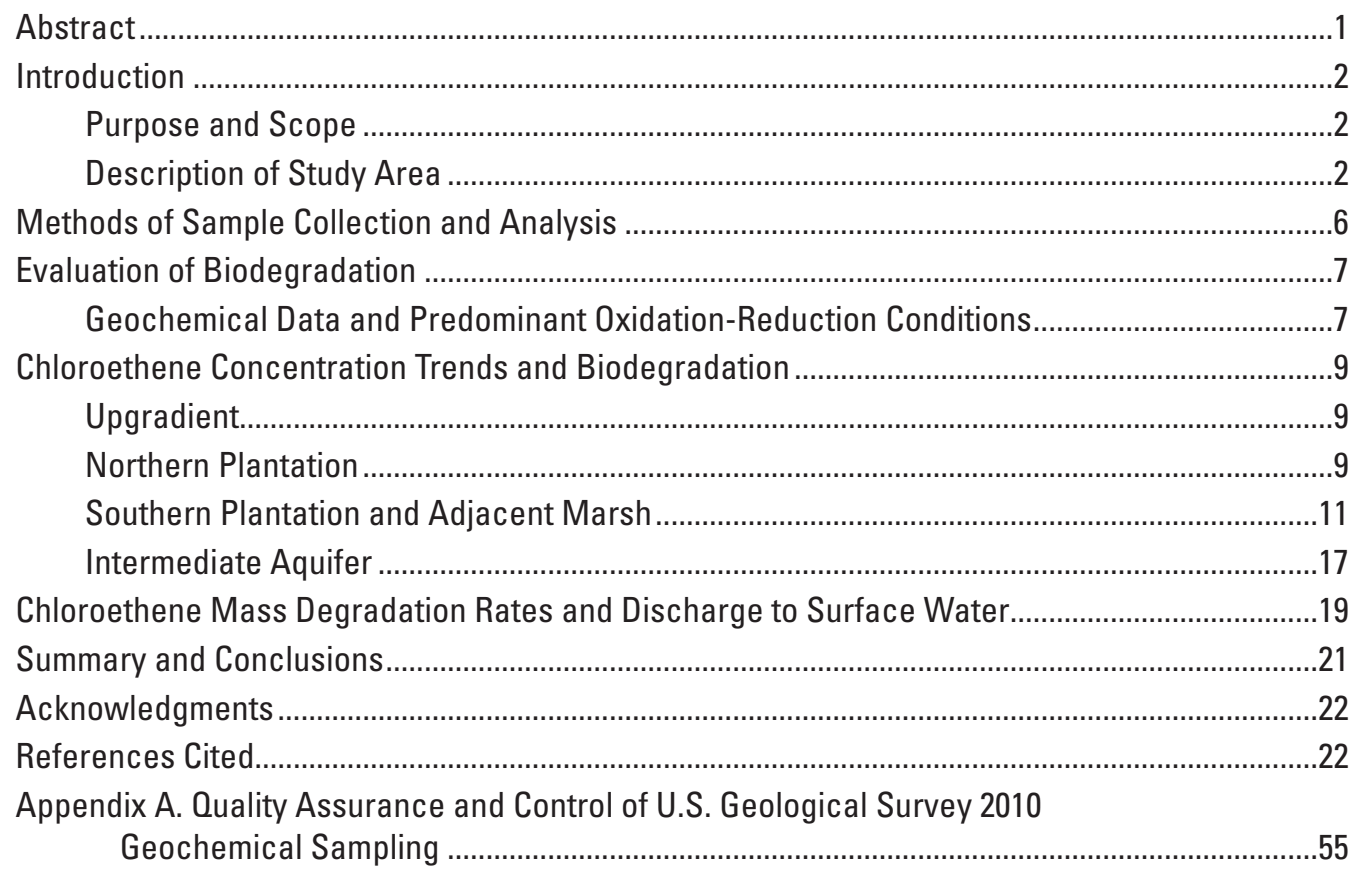

\section{Figures}

Figure 1. Map showing location of Operable Unit 1 study area, Naval Undersea Warfare Center, Division Keyport, Washington

Figure 2. Map showing location of former landfill, two phytoremediation plantations, and data-collection sites at Operable Unit 1, Naval Undersea Warfare Center (NUWC), Division Keyport, Washington.

Figure 3. Graph showing chloroethene concentration and ratio of cis-1,2-dichlorethene to vinyl chloride concentrations at northern plantation wells $1 \mathrm{MW}-1, \mathrm{MW} 1-2$, and piezometer P1-4 at Operable Unit 1, Naval Undersea Warfare Center, Division Keyport, Washington, 1991-2010

Figure 4. Graph showing ratio of trichlorethene to cis-1,2-dichlorethene concentrations at northern plantation wells and piezometers at Operable Unit 1, Naval Undersea Warfare Center, Division Keyport, Washington, 1996-2010

Figure 5. Graphs showing chloroethene concentration and ratio of cis-1,2-dichlorethene to vinyl chloride concentrations at southern plantation wells MW1-5 and MW1-16 and piezometers P1-6, P1-8, and P1-10 at Operable Unit 1, Naval Undersea Warfare Center, Division Keyport, Washington, 1991-2010

Figure 6. Graphs showing chloroethene concentration and ratio of cis-1,2-dichlorethene to vinyl chloride concentrations at southern plantation well MW1-4 and piezometers P1-7 and P1-9 at Operable Unit 1, Naval Undersea Warfare Center, Division Keyport, Washington, 1991-2010

Figure 7. Graphs showing ratio of trichloroethene to cis-1,2-dichlorethene concentrations at southern plantation wells and piezometers at Operable Unit 1, Naval Undersea Warfare Center, Division Keyport, Washington, 1999-2010 


\section{Figures-Continued}

Figure 8. Graphs showing chloroethene concentration and ratio of cis-1,2-dichlorethene to vinyl chloride concentrations at marsh passive-diffusion sampler sites S-4, S4-B, S-5, and S5-B at Operable Unit 1, Naval Undersea Warfare Center, Division Keyport, Washington, 2000-2010

Figure 9. Graph showing chloroethene concentration and ratio of cis-1,2-dichlorethene to vinyl chloride concentrations at surface water site MA-12 at Operable Unit 1, Naval Undersea Warfare Center, Division Keyport, Washington, 1991-2010. ...

Figure 10. Graphs showing chloroethene concentration and ratio of cis-1,2-dichloroethene to vinyl chloride concentrations at intermediate aquifer wells MW1-25 and MW1-28 at Operable Unit 1, Naval Undersea Warfare Center, Division Keyport, Washington, 1995-2010

Figure 11. Map showing transects and sub-transects where mass chloroethene fluxes were estimated for the upper aquifer at Operable Unit 1, Naval Undersea Warfare Center (NUWC), Division Keyport, Washington

\section{Tables}

Table 1. Wells and piezometers sampled and water levels measured at Operable Unit 1, Naval Undersea Warfare Center, Division Keyport, Washington, June 14-15, 2010

Table 2. Predominant redox conditions at wells and piezometers, and groundwater geochemical data collected at Operable Unit 1, Naval Undersea Warfare Center, Division Keyport, Washington, 1996-2010

Table 3. Potential relative efficiency of chloroethene biodegradation through reductive dechlorination or microbial oxidation as a function of groundwater reduction-oxidation (redox) conditions

Table 4. Concentrations of selected volatile organic compounds in water samples collected by the U.S. Geological Survey from selected monitoring wells, piezometers, and passive-diffusion samplers at Operable Unit 1, Naval Undersea Warfare Center, Division Keyport, Washington, 1999-2010

Table 5. Estimated chloroethene mass degradation rates and fluxes to surface water in the southern plantation and adjacent marsh at Operable Unit 1, Naval Undersea Warfare Center, Division Keyport, Washington, 1999-2010 


\section{Conversion Factors, Datums, and Abbreviations and Acronyms}

Inch/Pound to SI

\begin{tabular}{|c|c|c|}
\hline Multiply & By & To obtain \\
\hline \multicolumn{3}{|c|}{ Length } \\
\hline inch (in.) & 2.54 & centimeter (cm) \\
\hline inch (in.) & 25.4 & millimeter (mm) \\
\hline foot (ft) & 0.3048 & meter $(\mathrm{m})$ \\
\hline \multicolumn{3}{|c|}{ Area } \\
\hline acre & 4,047 & square meter $\left(\mathrm{m}^{2}\right)$ \\
\hline acre & 0.4047 & hectare (ha) \\
\hline acre & 0.004047 & square kilometer $\left(\mathrm{km}^{2}\right)$ \\
\hline \multicolumn{3}{|c|}{ Mass } \\
\hline ounce, avoirdupois & 28.4 & gram (g) \\
\hline
\end{tabular}

SI to Inch/Pound

\begin{tabular}{lcl}
\hline \multicolumn{1}{c}{ Multiply } & \multicolumn{1}{c}{ By } & \multicolumn{1}{c}{ To obtain } \\
\hline & Length & \\
\hline centimeter $(\mathrm{cm})$ & 0.3937 & inch (in.) \\
millimeter $(\mathrm{mm})$ & 0.03937 & inch (in.) \\
meter $(\mathrm{m})$ & 3.281 & foot (ft) \\
\hline \multicolumn{2}{c}{ Area } & \\
\hline square meter $\left(\mathrm{m}^{2}\right)$ & 0.0002471 & acre \\
hectare $($ ha) & 2.471 & acre \\
square kilometer $\left(\mathrm{km}^{2}\right)$ & 247.1 & acre \\
\hline & Mass & \\
\hline gram $(\mathrm{g})$ & 0.03527 & ounce, avoirdupois (oz) \\
\hline
\end{tabular}

Temperature in degrees Celsius $\left({ }^{\circ} \mathrm{C}\right)$ may be converted to degrees Fahrenheit $\left({ }^{\circ} \mathrm{F}\right)$ as follows:

$$
{ }^{\circ} \mathrm{F}=\left(1.8 x^{\circ} \mathrm{C}\right)+32 .
$$

Specific conductance is given in microsiemens per centimeter at 25 degrees Celsius $(\mu \mathrm{S} / \mathrm{cm}$ at $\left.25^{\circ} \mathrm{C}\right)$.

Concentrations of chemical constituents in water are given either in milligrams per liter ( $\mathrm{mg} / \mathrm{L}$ ) or micrograms per liter $(\mu \mathrm{g} / \mathrm{L})$.

Concentrations of chemical constituents in water are given either in milligrams per liter (mg/L) or micrograms per liter $(\mu \mathrm{g} / \mathrm{L})$. 
Datums

Vertical coordinate information is referenced to North American Vertical Datum of 1988 (NAVD 88).

Horizontal coordinate information is referenced to North American Datum of 1927 (NAD 27).

Altitude, as used in this report, refers to distance above the vertical datum.

Abbreviations and Acronyms

$\begin{array}{ll}\text { 1,1-DCA } & \text { 1,1-dichloroethane } \\ \text { 1,2-DCA } & \text { 1,2-dichloroethane } \\ \text { 1,1-DCE } & \text { 1,1-dichloroethene } \\ \text { cis-DCE } & \text { cis-1,2-dichloroethene } \\ \text { CVOC } & \text { chlorinated volatile organic compound } \\ \text { DO } & \text { fissolved oxygen } \\ \text { DOC } & \text { milliliter } \\ \text { mL } & \text { millivolt } \\ \text { mV } & \text { nanomolar } \\ \text { nM } & \text { Naval Undersea Warfare Center } \\ \text { NUWC } & \text { USGS National Water Quality Laboratory } \\ \text { NWQL } & \text { oxidation-reduction potential } \\ \text { ORP } & \text { Operable Unit 1 } \\ \text { OU 1 } & \text { tetrachloroethene } \\ \text { PCE } & 1,1,1 \text {-trichloroethane } \\ \text { TCA } & \text { trichloroethene } \\ \text { TCE } & \text { trans-1,2-dichloroethene } \\ \text { trans-DCE } & \text { U.S. Geological Survey } \\ \text { USGS } & \text { vinyl chloride } \\ \text { VC } & \text { volatile organic compound } \\ \text { VOC } & \end{array}$




\title{
Biodegradation of Chloroethene Compounds in Groundwater at Operable Unit 1, Naval Undersea Warfare Center, Division Keyport, Washington, 1999-2010
}

\author{
By R.S. Dinicola and R.L. Huffman
}

\begin{abstract}
The U.S. Geological Survey evaluated the biodegradation of chloroethene compounds in groundwater beneath the former landfill at Operable Unit 1 (OU 1) of the U.S. Naval Undersea Warfare Center (NUWC), Division Keyport. The predominant contaminants in groundwater are the chloroethene compounds trichloroethene, cis-1,2-dichloroethene, and vinyl chloride. The remedy selected for groundwater contamination at OU 1 includes phytoremediation and natural attenuation. In 1999, the U.S. Navy planted two hybrid poplar plantations, referred to as the northern and southern plantations, over the most contaminated parts of the landfill. The U.S. Navy monitors tree health, groundwater levels, and contaminant concentrations to assess the effectiveness of phytoremediation. The U.S. Geological Survey began a cooperative effort with the U.S. Navy in 1995 to monitor the effectiveness of natural attenuation processes for removing and controlling the migration of chloroethenes and chloroethanes. Field and laboratory studies from 1996 through 2000 demonstrated that biodegradation of chloroethenes and chloroethanes in shallow groundwater at OU 1 was substantial. The U.S. Geological Survey monitored geochemical and contaminant concentrations in groundwater annually from 2001 through 2010. This report presents groundwater geochemical and contaminant data collected by the U.S. Geological Survey during June 2010 and evaluates evidence for continued biodegradation of chloroethenes in groundwater.
\end{abstract}

\author{
Geochemical and contaminant concentration data \\ through 2010 indicate that biodegradation of chloroethenes \\ in groundwater continued beneath the landfill at OU 1. \\ Contaminant concentrations in groundwater decreased beneath \\ most of the 9-acre landfill between 1999 and 2010. The \\ evidence indicating that biodegradation was a primary cause \\ for the decreased concentrations included decreasing ratios \\ of more highly chlorinated compounds to less chlorinated \\ compounds over time, and widespread detections of non- \\ chlorinated biodegradation end-products ethane and ethene. \\ No widespread changes in groundwater reduction-oxidation \\ (redox) conditions were observed that could result in either \\ more or less efficient biodegradation. \\ Even with continued biodegradation, dissolved-phase \\ contaminant concentrations in the tens of milligrams per liter \\ have persisted beneath part of the 0.7 -acre southern plantation. \\ The magnitude and persistence of those concentrations \\ indicate that non-aqueous phase liquid chloroethenes likely \\ are present beneath the southern plantation and are not \\ substantially affected by biodegradation. During 2010, \\ chloroethenes continued to be measured in shallow \\ groundwater samples from the southern part of the adjacent \\ marsh, although at the lowest concentrations ever measured. \\ Flux calculations based on 2010 data indicate that \\ 95 percent of dissolved-phase chloroethenes in the upper \\ aquifer beneath the southern landfill were degraded before \\ discharging to surface water. Overall, biodegradation of \\ chloroethenes in groundwater throughout OU 1 continued \\ through 2010, and it prevented most of the mass of \\ dissolved-phase chloroethenes in the upper aquifer beneath the \\ landfill from discharging to surface water.
}




\section{Introduction}

Chlorinated volatile organic compounds (CVOCs) have migrated to groundwater beneath a former 9-acre landfill at Operable Unit 1 (OU 1) of the Naval Undersea Warfare Center (NUWC), Division Keyport, Washington (fig. 1). The predominant groundwater contaminants are the chloroethene compounds trichloroethene (TCE); cis-1,2-dichloroethene (cis-DCE); and vinyl chloride (VC). Less predominant contaminants include tetrachloroethene (PCE); trans-1,2-dichloroethene (trans-DCE); 1,1-dichloroethene (1,1-DCE); and the chloroethane compounds 1,1,1-trichloroethane (TCA); 1,1-dichloroethane (1,1-DCA); and 1,2-dichloroethane (1,2-DCA). A need for remedial action was identified because some of the contaminants present a potential risk to humans, primarily through drinking contaminated groundwater or through ingesting seafood harvested from contaminated surface water (URS Consultants, Inc., 1998).

The U.S. Navy began a cooperative effort with the U.S. Geological Survey (USGS) in 1995 to evaluate the effectiveness of natural attenuation processes for removing and controlling the migration of CVOCs in groundwater at OU 1. Field and laboratory studies from 1996 through 2000 demonstrated that biodegradation of CVOCs in shallow groundwater at OU 1 is substantial (URS Consultants, Inc., 1997a; Bradley and others, 1998; Dinicola and others, 2002). In 1998, a remedy was developed for contaminated groundwater at OU 1 that includes phytoremediation and ongoing natural attenuation processes to remove and control the migration of CVOCs in shallow groundwater (URS Consultants, Inc., 1998). In 1999, the U.S. Navy planted two hybrid poplar plantations in two areas on the landfill where contaminant concentrations in groundwater were exceptionally high (fig. 2) (URS Greiner, Inc., 1999). The U.S. Navy regularly monitored contaminant concentrations in groundwater and surface water, along with tree health and water levels, to determine the effectiveness of phytoremediation (CH2M Hill Constructors, Inc., 2002, 2003, 2004, and 2005). The USGS monitored geochemistry and contaminant concentrations in groundwater and surface water annually from 2001 through 2010 to evaluate reduction-oxidation (redox) conditions and CVOC biodegradation (Dinicola, 2003, 2004, 2006; Dinicola and Huffman, 2004, 2006, 2007, 2009; Huffman and Dinicola, 2011).

\section{Purpose and Scope}

This report presents groundwater geochemical and selected CVOC data collected by the USGS at OU 1 during June 14-15, 2010, and evaluates evidence for continued biodegradation of chloroethenes in groundwater at OU 1. Biodegradation of chloroethanes was not specifically evaluated because those contaminants are greatly limited in extent at the site. Data used for the evaluation included CVOC and geochemical data collected during 2000-2010 by the USGS (Huffman and Dinicola, 2011) and the U.S. Navy (2010) in addition to data presented in a prior evaluation of biodegradation (Dinicola and others, 2002).

In June 2010, the USGS collected water samples from 13 wells and 9 piezometers (table 1 and fig. 2) to determine volatile organic compound (VOC) concentrations and concentrations of redox-sensitive analytes. The USGS also sampled VOCs in shallow groundwater directly beneath the marsh stream and pond (ig. 2) using passive-diffusion samplers. Samplers were deployed in the same locations that were sampled by the USGS in June 2000 and 2004 (Dinicola, 2006).

\section{Description of Study Area}

NUWC, Division Keyport is on a small peninsula in Kitsap County, Washington, in an extension of Puget Sound called Liberty Bay (fig. 1). The landfill at OU 1 is on the narrow strip of land connecting the peninsula to the mainland and is adjacent to tidal flats that are an extension of Dogfish and Liberty Bays (fig. 2). The OU 1 landfill is unlined and was constructed in a marshland. The landfill was the primary disposal area for domestic and industrial wastes generated by NUWC, Division Keyport from the 1930s through 1973. Paints, thinners, solvents, acids, dried sludge from a wastewater-treatment plant, and other industrial wastes were disposed in the landfill. The most concentrated disposal area for waste paints and solvents was at the southern end of the landfill. 


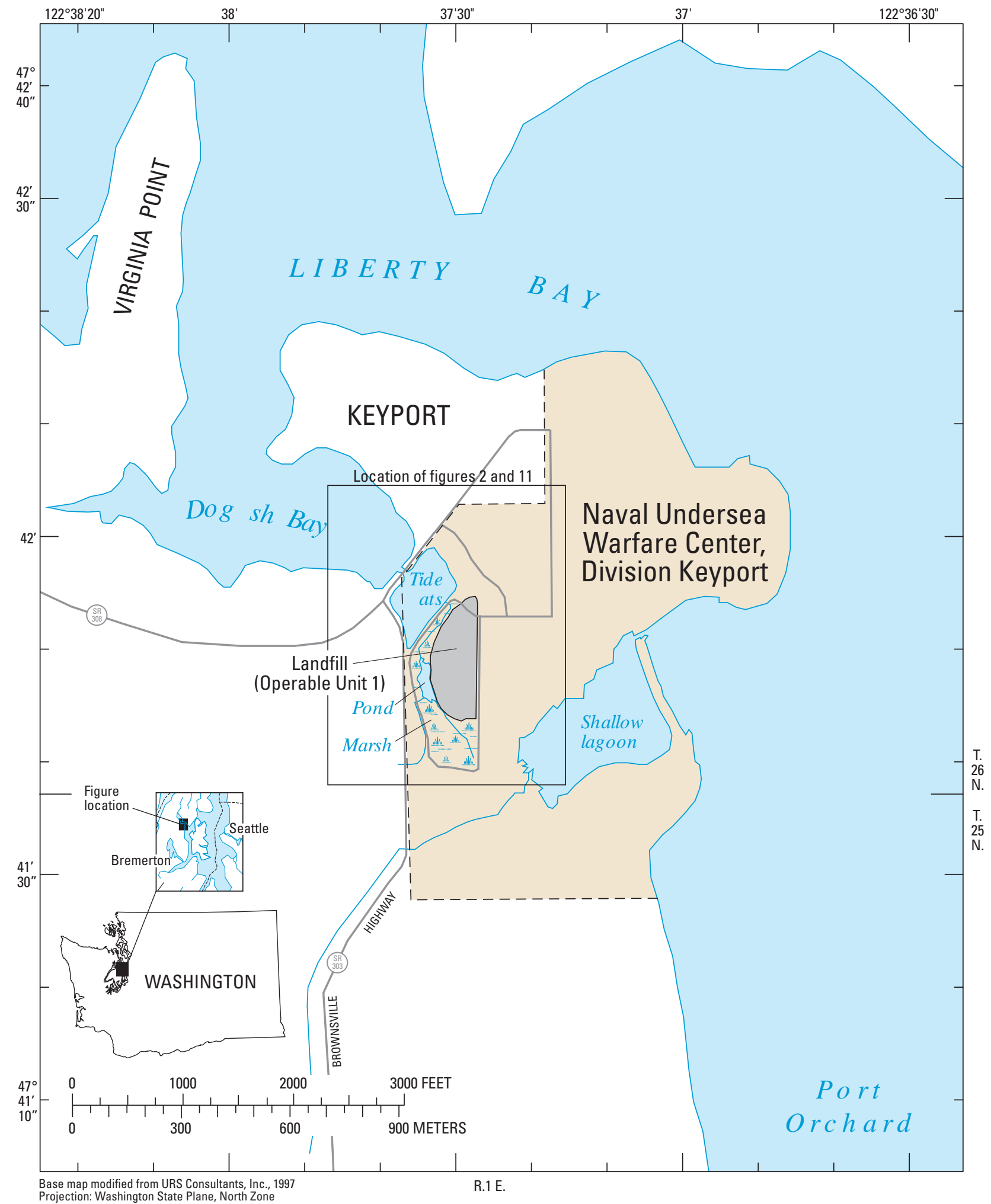

Figure 1. Location of Operable Unit 1 study area, Naval Undersea Warfare Center, Division Keyport, Washington. 


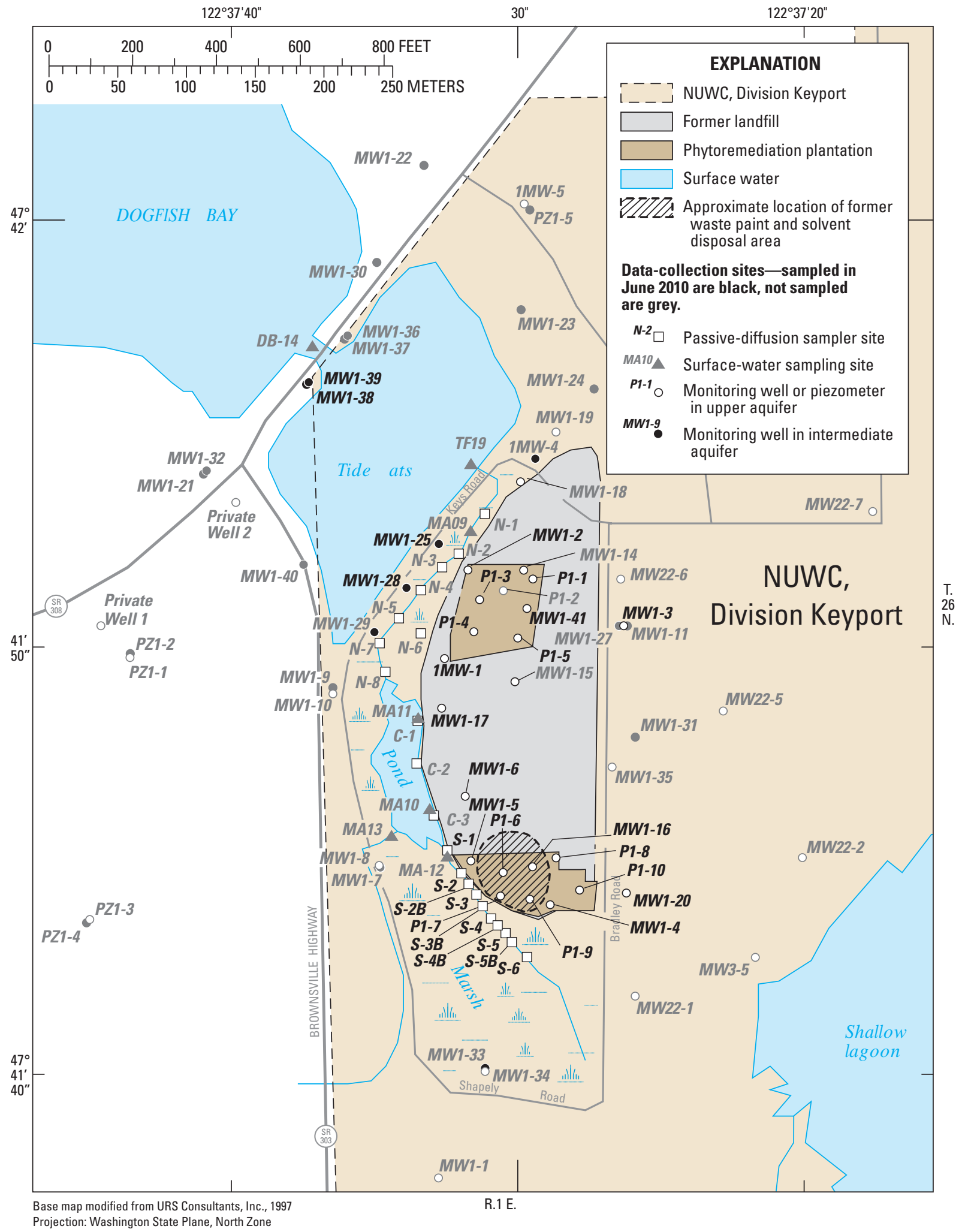

Figure 2. Location of former landfill, two phytoremediation plantations, and data-collection sites at Operable Unit 1, Naval Undersea Warfare Center (NUWC), Division Keyport, Washington. 
Table 1. Wells and piezometers sampled and water levels measured at Operable Unit 1, Naval Undersea Warfare Center, Division Keyport, Washington, June 14-15, 2010.

[Well or piezometer site No.: MW, monitoring well; P, piezometer; USGS site No.: Unique number for each site based on latitude and longitude of the site. First six digits are latitude, next seven digits are longitude, and final two digits are a sequence number to uniquely identify each site. Altitudes of water levels and measuring points are given in feet above or below (-) North American Vertical Datum of 1988. Water level is in feet below measuring point (bmp). Depth of well and screened interval are in feet below land surface. Altitude of measuring point: Water levels in wells are usually reported as depths below land surface, although the measuring point can be any convenient fixed place near the top of the well. For these wells and piezometers, the measuring points are marked points on the tops of well casings - they vary from being near the land surface to a few feet above land surface. The altitude of the measuring point is commonly recorded so that static water levels also can be reported as altitudes. Abbreviations: USGS, U.S. Geological Survey; VOC, volatile organic compound; ft, foot; $\mathrm{ft}$ bmp, feet below measuring point; $m$, meter]

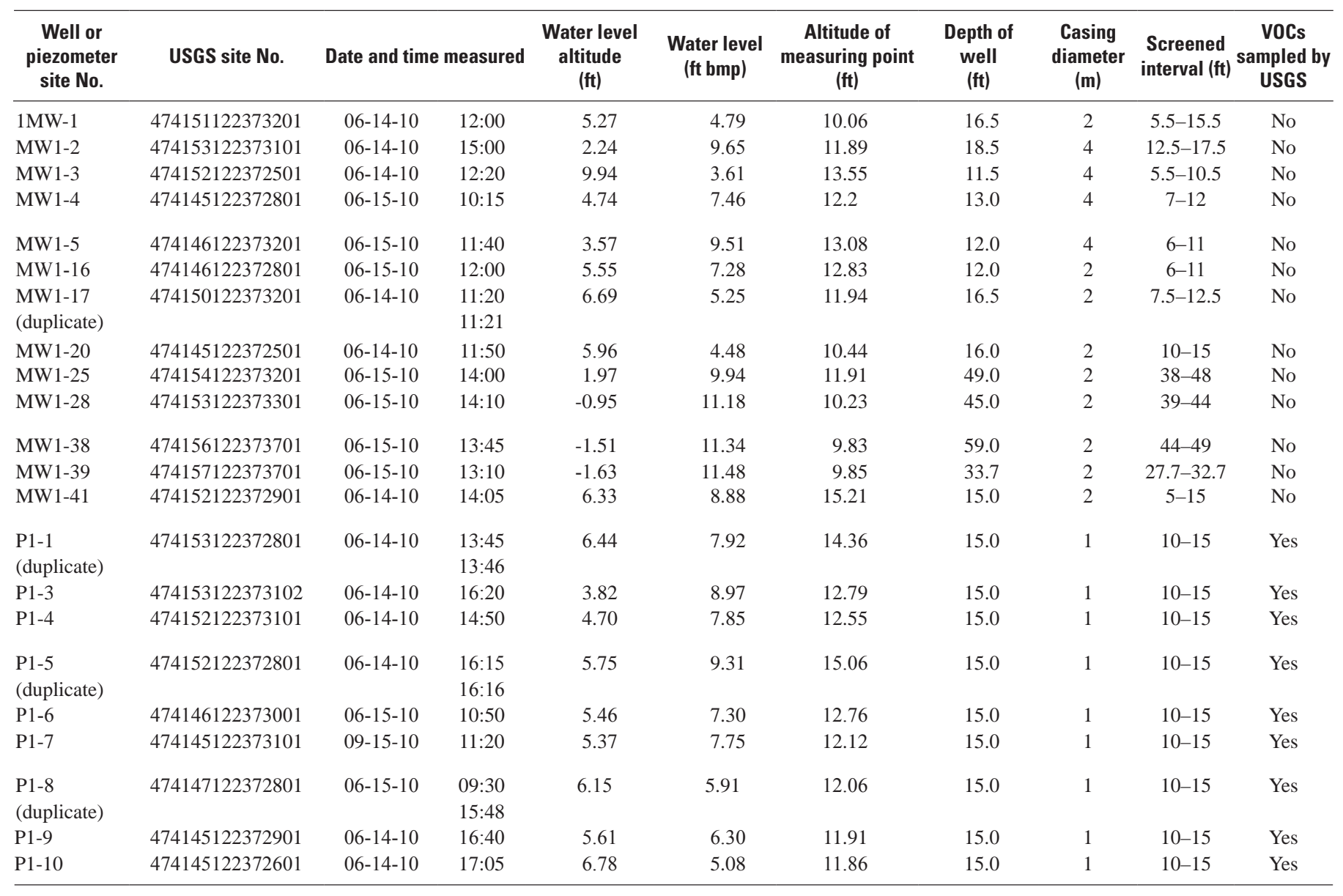




\section{Methods of Sample Collection and Analysis}

Water-level measurements, sample collection and processing, and field analyses were in accordance with applicable USGS procedures as described in the National Field Manual (U.S. Geological Survey, variously dated). Redox-sensitive analyte measurements and concentrations that were determined for samples from 13 wells and 9 piezometers included dissolved hydrogen $\left(\mathrm{H}_{2}\right)$, dissolved oxygen (DO), filtered (dissolved) organic carbon (DOC), filtered nitrate plus nitrite, filtered manganese, filtered ferrous iron (or iron [II]), filtered sulfate, unfiltered sulfide, dissolved methane, dissolved carbon dioxide, $\mathrm{pH}$, specific conductance, and filtered chloride. Concentrations of 29 VOCs were determined for samples from 11 of the 13 wells, from all 9 piezometers, and from all 9 passive-diffusion samplers deployed. The concentrations of dissolved gasses ethane, ethene, and methane also were determined for samples from all 13 wells and from all piezometers.

After measuring depth to water, all well and piezometer samples were collected with a peristaltic pump and single-use polyethylene tubing. Samples were collected after about three casing-volumes of water were purged from the wells and after allowing field measurements of $\mathrm{pH}$, specific conductance, and DO to stabilize to within 0.1 unit, 3 percent, and $0.3 \mathrm{mg} / \mathrm{L}$, respectively. Field measurements were monitored with a flow-through chamber using a YSI ${ }^{\circledR}$ Inc. 600XLM or $6920 \mathrm{~V} 2$ data sonde. The sonde was calibrated prior to use as described in the National Field Manual (U.S. Geological Survey, variously dated, chaps. 6 and 8). The specific conductance sensor was calibrated daily with standard reference solutions $(1,000 \mu \mathrm{S} / \mathrm{cm}$ and verified with solutions ranging from $250-1,000 \mu \mathrm{S} / \mathrm{cm}$ ); the $\mathrm{pH}$ sensor was calibrated daily with $2 \mathrm{pH}$ standards (at $\mathrm{pH} 7$ and 10, and verified against $\mathrm{pH} 4$ buffer solution); and the DO sensor was calibrated daily using the air saturated water method and occasionally verified with zero-DO solution. Dissolved oxygen analyses were confirmed for most samples using 0-1 mg/L CHEMets ${ }^{\circledR}$ Rhodazine- $\mathrm{D}^{\mathrm{TM}}$ colorimetric vacuum ampoules (manufactured by CHEMetrics ${ }^{\circledR}$, Inc., Calverton, Virginia).

Concentrations of iron (II) were measured in field samples filtered through a $0.45 \mu \mathrm{m}$ membrane filter using a colorimetric 1,10-phenanthroline indicator method and using a Hach Model 2010 spectrophotometer following Hach Method 8146 [Hach Company (1998), adapted from American Public Health Association (1980)]. Sulfide concentrations were measured in the field immediately after collection with a colorimetric methylene-blue indicator and a spectrophotometer, according to Hach Method 8131 [Hach Company(1998), the procedure equivalent to U.S. Environmental Protection Agency method 376.2 (U.S.
Environmental Protection Agency, 1983)]. Dissolved carbon dioxide $\left(\mathrm{CO}_{2}\right)$ concentrations were measured in the field using Titret ${ }^{\circledR}$-Sodium hydroxide titrant with a $\mathrm{pH}$ indicator (manufactured by CHEMetrics, Inc., Calverton, Virginia).

Samples for analysis of dissolved $\mathrm{H}_{2}$ in groundwater was collected using the bubble-strip method and concentrations were measured in the field using a gas chromatograph equipped with a reduction gas detector as described by Chapelle and others (1997). Initial gas samples from each well were collected and analyzed after at least 20 minutes of stripping; subsequent samples were collected and analyzed at about 5-minute intervals until consecutive $\mathrm{H}_{2}$ concentrations stabilized to within 10 percent, a process that often required an hour or longer.

Samples for analysis of nitrate plus nitrite, manganese, sulfate, and chloride concentrations were filtered through a $0.45-\mu \mathrm{m}$ membrane filter into polyethylene bottles, chilled, and sent to the USGS National Water Quality Laboratory (NWQL) in Lakewood, Colorado. Samples for analysis of manganese were filtered into an acid-rinsed bottle, acidified in the field with nitric acid to a $\mathrm{pH}$ of less than 2 , and then shipped to the NWQL for analysis by inductively coupled plasma as described by Fishman (1993). Chloride and sulfate were analyzed using ion chromatography as described by Fishman and Friedman (1989). Nitrate plus nitrite were analyzed colorimetrically by cadmium reduction and diazotization as described by Fishman (1993). The results for the nitrate plus nitrite analyses are referred to simply as "nitrate" in this report because nitrite was not detected at the site (Dinicola and others, 2002).

Samples for DOC analysis were filtered through a $0.45-\mu \mathrm{m}$ filter into amber glass bottles, acidified in the field with sulfuric acid to a $\mathrm{pH}$ of less than 2 , chilled to less than $4^{\circ} \mathrm{C}$, and shipped to the NWQL. Organic carbon concentrations were determined using persulfate oxidation as described by Brenton and Arnett (1993).

Samples for VOC analysis were collected in pre-acidified $40 \mathrm{~mL}$ glass vials, placed on ice, and shipped to the NWQL for subsequent analysis using purge and trap capillary-column gas chromatography/mass spectrometry as described by Connor and others (1998). Samples for analysis of ethane, ethene, and methane were collected in pre-acidified $40 \mathrm{~mL}$ glass vials, placed on ice, and shipped to Test America Laboratory in Denver, Colorado, for subsequent analysis using gas chromatography with a flame ionization detector (U.S. Environmental Protection Agency, 1994; Kampbell and Vandegrift, 1998).

Ten passive-diffusion samplers were deployed beneath the marsh stream south and west of the southern plantation (fig. 2) to determine VOC samples in shallow groundwater. The diffusion samplers consisted of 2-in. diameter polyethylene lay-flat tubing (8-in. long) filled with deionized water and heat sealed at both ends. The diffusion samplers 
were built by the USGS, in Tacoma, Washington, following protocols outlined by Vorblesky (2001a). The filled diffusion samplers were inserted into plastic mesh sleeves to protect them from damage, and were placed in 12 in. deep hand-dug holes in the streambed at designated locations along the southern end of the marsh. The holes were backfilled with native sediment, tamped down, and left to equilibrate with the surrounding pore water for two weeks. Immediately upon hand retrieval, a corner of each diffusion sampler was cut, then three pre-acidified $40 \mathrm{~mL}$ glass VOC vials were filled, sealed, and kept on ice for shipment to the NWQL for VOC analysis.

Quality assurance and control of geochemical and contaminant sampling included collecting two duplicate samples for selected redox-sensitive analytes and VOCs, and analyzing a field blank sample for VOCs and redox-sensitive analytes. No substantial quality issues were identified in those samples (appendix A).

\section{Evaluation of Biodegradation}

In the previous USGS evaluation of natural attenuation at OU 1 (Dinicola and others, 2002; Dinicola, 2006), biodegradation was determined to be responsible for substantially reducing the contaminant mass at OU 1 and for preventing most of the mass of dissolved-phase chloroethenes in the upper aquifer beneath the landfill from discharging to surface water. For this report, the 2001-2010 data were examined for evidence of continued biodegradation of chloroethenes. Redox-sensitive analyte (iron [II], nitrate, hydrogen sulfide, methane, DOC, and $\mathrm{H}_{2}$ ) data were used to evaluate redox conditions within the groundwater to determine if any changes occurred that could result in either more or less efficient biodegradation. Changes in absolute and relative concentrations of contaminants were examined as direct evidence of continued biodegradation. The rate at which the contaminant mass at OU 1 was degraded in groundwater and the rate at which contaminants were discharged to surface water during 2010 were calculated and compared to rates previously calculated for 1999-2000, 2004, and 2005 conditions.

For convenience in following the discussion, the sampled wells and piezometers are grouped by location and aquifer. "Upgradient" sampling sites refer to the two upper aquifer wells (MW1-3 and MW1-20). "Northern plantation" and "southern plantation" sampling sites are all upper aquifer wells and piezometers in or near the respective phytoremediation plantations. "Intermediate aquifer" sampling sites refer to all intermediate aquifer wells that are downgradient of the landfill. No intermediate aquifer wells are in the footprint of the former landfill. "Marsh" sampling sites refer to the ten passive-diffusion samplers deployed in the marsh near the southern plantation.

\section{Geochemical Data and Predominant Oxidation-Reduction Conditions}

Predominant oxidation-reduction (redox) conditions were inferred by analyzing various oxidized and reduced inorganic compounds in groundwater samples, as well as through direct measurement and interpretation of dissolved $\mathrm{H}_{2}$ concentrations in groundwater samples (Dinicola, 2006).

Redox conditions generally were considered aerobic when DO concentrations were $1 \mathrm{mg} / \mathrm{L}$ or greater, or anaerobic when DO concentrations were less than $1 \mathrm{mg} / \mathrm{L}$. Anaerobic redox conditions were further specified (and named) according to the inorganic compound acting as the predominant electron acceptor in a given part of an aquifer. Common anaerobic redox conditions in groundwater are nitrate reducing, manganese reducing, iron reducing, sulfate reducing, and carbon dioxide reducing (methanogenic). Nitrate reduction, manganese reduction and iron reduction commonly are together referred to as mildly reducing conditions, whereas sulfate reduction and methanogenesis commonly are referred to as strongly reducing conditions. That distinction is made because different types of biodegradation processes are favored under mildly and strongly reducing conditions. Determination of the different anaerobic redox conditions in contaminated groundwater at OU 1 is summarized here; a more detailed description of the rationale used is described by Dinicola (2006).

For anaerobic redox conditions indicated by DO concentrations less than $1 \mathrm{mg} / \mathrm{L}$, nitrate reduction was considered predominant if nitrate concentrations exceed about $0.5 \mathrm{mg} / \mathrm{L}$. If anaerobic groundwater lacked nitrate, and if reduced manganese or iron (II) concentrations increased along a groundwater flow path, then manganese or iron reduction was indicated. If anaerobic groundwater lacked nitrate, if sulfate (oxidized sulfur) concentrations decreased along a groundwater flow path, and if hydrogen sulfide (reduced sulfur) concentrations exceeded about $0.05 \mathrm{mg} / \mathrm{L}$, then sulfate reduction was indicated. Finally, if anaerobic groundwater lacked nitrate, sulfate, and hydrogen sulfide, and if methane concentrations exceeded about $0.2 \mathrm{mg} / \mathrm{L}$, then carbon dioxide reduction (methanogenesis) was indicated.

Many conditions at the OU 1 landfill complicate the determination of redox conditions. Contaminated groundwater beneath landfills often is not at thermodynamic equilibrium, so several electron-accepting processes may occur simultaneously (Christensen and others, 2000; Cozzarelli and others, 2000). An alternative method for identifying the predominant redox processes in anaerobic groundwater is through direct measurement and interpretation of dissolved $\mathrm{H}_{2}$ concentrations in groundwater (Lovely and others, 1994; Chapelle and others, 1995). Hydrogen is continuously produced and consumed by different microorganisms during 
anaerobic decomposition of organic matter. For natural groundwaters, different microorganisms that facilitate nitrate-, manganese-, iron-, sulfate-, and carbon dioxide-reduction reactions exhibit different efficiencies using $\mathrm{H}_{2}$ (Lovely and Goodwin, 1988). Nitrate reducers are efficient at using $\mathrm{H}_{2}$ and keeping dissolved $\mathrm{H}_{2}$ concentrations in groundwater at levels less than $0.1 \mathrm{nM}$. Manganese and iron reducers use $\mathrm{H}_{2}$ less efficiently and keep $\mathrm{H}_{2}$ concentrations between 0.1 and $0.2 \mathrm{nM}$ and 0.2 and $0.8 \mathrm{nM}$, respectively. Sulfate reducers are even less efficient and keep $\mathrm{H}_{2}$ concentrations between 1 and $4 \mathrm{nM}$; and carbon dioxide reducers are relatively inefficient, resulting in $\mathrm{H}_{2}$ concentrations greater than $5 \mathrm{nM}$. The result of competition for $\mathrm{H}_{2}$ is that each anaerobic redox condition is characterized by a distinct $\mathrm{H}_{2}$ concentration in groundwater (Lovely and others, 1994; Chapelle and others, 1995).

Redox-sensitive analytical data from many OU 1 groundwater samples indicate multiple redox conditions near the sampled well or piezometer (table 2) (at back of report).

At the upgradient wells within the upper aquifer (wells MW1-3 and MW1-20), predominant redox conditions from 1998 to 2010 varied between aerobic, manganese-reducing, iron-reducing, and sulfate-reducing (table 2). Filtered (dissolved) organic carbon (DOC) concentrations consistently were less than or equal to $2 \mathrm{mg} / \mathrm{L}$, and methane concentrations were consistently less than $0.3 \mathrm{mg} / \mathrm{L}$. Although these wells are upgradient of the landfill, they are downgradient of the military base industrial and office areas and are near stormwater swales; therefore, upper-aquifer water flowing into OU 1 is not pristine. The upgradient well in the intermediate aquifer (MW1-33), which historically did not appear to be influenced by local land use, was not sampled due to the well being decommissioned.

At the northern plantation sites, predominant redox conditions in shallow groundwater were consistently anaerobic during 1996-2010 (table 2). The specific redox conditions during 2010 ranged from iron-reducing to sulfate-reducing, although the widespread detection of methane (0.73-27 mg/L during 2010) indicated that methanogenic conditions also were present. DOC concentrations in the northern part of the landfill (5.4-19 mg/L in 2010) were consistently greater than concentrations measured in upgradient wells, indicating that the landfill is a source of organic substrate essential for reductive dechlorination, although the DOC concentrations generally were less than those previously measured. Throughout the northern plantation and vicinity, no consistent trends were apparent in the predominant redox conditions determined by the redox-sensitive analyte concentrations since 1996.

At the southern plantation sites, predominant redox conditions in shallow groundwater also were consistently anaerobic during 1996-2010 (table 2). The specific redox conditions ranged from iron/manganese-reducing to methanogenic, with mildly reducing conditions more common than strongly reducing conditions. DOC concentrations in the southern part of the landfill (1.2-14 $\mathrm{mg} / \mathrm{L}$ during 2010), were consistently greater than concentrations measured in upgradient wells. Similar to the northern plantation, no consistent trends developed in predominant redox conditions or in most redox-sensitive analyte concentrations since 1996 throughout the southern plantation.

At the intermediate aquifer sites, predominant redox conditions were consistently anaerobic during 1996-2010 (table 2). For intermediate aquifer wells at the downgradient margin of the landfill (MW1-25 and MW1-28), the specific redox conditions ranged from iron/manganese-reducing to methanogenic, with iron-reducing conditions measured most frequently. For intermediate aquifer wells northwest of the tide flats (MW1-38 and MW1-39), the specific redox conditions ranged from iron-reducing to methanogenic. Redox conditions at the only contaminated well northwest of the tide flats (MW1-39) were predominantly sulfate-reducing. DOC concentrations in the intermediate aquifer downgradient of the landfill (2.0-6.6 $\mathrm{mg} / \mathrm{L}$ during 2010) were consistently greater than concentrations measured in the upgradient wells MW1-3 and MW1-20. Similar to the upper aquifer, no consistent trends in redox conditions, or in most redox-related geochemical concentrations, developed since 1996 in intermediate aquifer wells downgradient of the landfill.

Overall, no widespread changes in geochemical data and redox conditions occurred since 1996 at OU 1 that could result in either more or less efficient biodegradation. Redox conditions varied substantially from year to year (particularly in the upper aquifer), but no consistent trend developed towards either more strongly or more mildly reducing conditions. Occasional detections of sulfide, widespread detections of methane, and frequent detections of dissolved $\mathrm{H}_{2}$ at concentrations greater than $1 \mathrm{mg} / \mathrm{L}$ indicate that the strongly reducing conditions of sulfate-reduction and methanogenesis were present in much of the upper aquifer beneath the landfill and in parts of the intermediate aquifer downgradient of the landfill. These redox conditions are most favorable for reductive dechlorination of all chloroethenes (table 2). Mildly reducing conditions, which are moderately favorable for reductive dechlorination of TCE, but are less favorable for reductive dechlorination of cis-DCE and VC, are present in the remainder of the contaminated parts of the upper and intermediate aquifers. Mildly reducing groundwater is favorable for microbial oxidation of VC (and to a lesser extent, cis-DCE), so the lack of strongly reducing conditions and reductive dechlorination throughout the system likely would not lead to an accumulation of VC in downgradient wells. 


\section{Chloroethene Concentration Trends and Biodegradation}

Contaminant degradation is the transformation of a chemical compound (the parent compound) into one or more other compounds (daughter products). Biodegradation reactions are mediated by subsurface microorganisms, whereas abiotic degradation reactions are not. Numerous field and laboratory studies have shown that microbes indigenous to groundwater systems can degrade chloroethenes (see Bradley, 2003, for a historical review). The most relevant degradation mechanisms for TCE, cis-DCE, and VC are summarized here.

Biodegradation mechanisms for chloroethenes can be categorized into two groups - reductive dechlorination and microbial oxidation (Bradley, 2003). The occurrence and efficiency of chloroethene biodegradation are sensitive to the redox conditions of groundwater (table 3) (at back of report). Reductive dechlorination mechanisms are most favorable under strongly reducing redox conditions (sulfate reduction and methanogenesis); and are most efficient for biodegradation of the highly chlorinated compounds PCE and TCE to form the daughter products cis-DCE and VC; and are commonly occurring in anaerobic groundwater. The potential for reductive dechlorination of VC to form ethane and ethene is less common and requires strongly reducing redox conditions.

In contrast, microbial oxidation mechanisms are most favorable under aerobic or mildly reducing redox conditions (manganese and iron reduction), and are most efficient for biodegradation of the less-chlorinated compounds cis-DCE and VC. Widespread occurrence of microbial oxidation mechanisms is not as well documented as that of reductive dechlorination, in part because the oxidation daughter products carbon dioxide and chloride are not uniquely diagnostic to chloroethene biodegradation. The potential for microbial oxidation mechanism under aerobic conditions is substantial where an anaerobic contaminant plume encounters aerobic water (such as at a discharge point to surface water). Likewise, the potential for microbial oxidation of VC and cis-DCE under anaerobic conditions is substantial in contaminant plumes where redox conditions are only mildly reducing.

Chlorinated VOC data were collected by the USGS from piezometers, selected wells, and passive-diffusion samplers at OU 1 in June 2010 (table 4) (at back of report). Complete analytical results (including data qualifiers) are available from the USGS National Water Information System (U.S. Geological Survey, 2011). Cumulative summaries of the 2001-09 CVOC data collected by the U.S. Navy and the USGS are available in U.S. Navy (2010) and Huffman and
Dinicola (2011), respectively. Selected historical chloroethene data previously published are presented graphically in this report. In the following discussions of trends in contaminant concentrations, there is uncertainty because of relatively few samples available at some sites, and from varying minimum reporting levels for selected contaminants.

\section{Upgradient}

The U.S. Navy has regularly measured CVOC concentrations in upgradient wells, although the USGS has not. Historically, only one chloroethene, TCE, was detected once during 1999 at upgradient well MW1-3 at a concentration of $0.70 \mu \mathrm{g} / \mathrm{L}$; no other chloroethenes have been detected at upgradient wells since monitoring began in 1991 (Dinicola and others, 2002; U.S. Navy, 2010).

\section{Northern Plantation}

Chloroethene concentrations at the three most contaminated sample sites in the northern plantation (wells 1MW-1, MW1-2, and piezometer P1-4) generally decreased over the periods of record (fig. 3 ). Chloroethene concentrations at piezometers P1-1, P1-3, and P1-5 in the northern plantation also have decreased substantially since 1999 (table 4).

Decreasing concentration ratios of the more highly chlorinated compound cis-DCE to the less chlorinated compounds VC over time (fig. 3) indicate that reductive dechlorination of cis-DCE is a substantial cause for the downward trend in contaminant concentrations beneath the northern plantation. Despite the continued production of VC through reductive dechlorination of cis-DCE, VC concentrations also decreased, although not as consistently as TCE and cis-DCE in the vicinity of the northern plantation (see wells 1MW-1 and MW1-2, fig. 3). Reductive dechlorination of $\mathrm{VC}$ is indicated by ethane plus ethene concentrations as high as $143 \mu \mathrm{g} / \mathrm{L}$ in a sample from well 1MW-1 (table 4). Microbial oxidation of VC (and cis-DCE to a lesser extent) also may be occurring in the iron- and manganese-reducing parts of the aquifer, but no unique diagnostic byproducts reliably indicate that process. Trends in the ratio of TCE:cis-DCE concentrations at northern plantation wells and piezometers (fig. 4) have been less determinant because TCE concentrations have commonly been near or less than the reporting level since 1999 (fig. 3). 

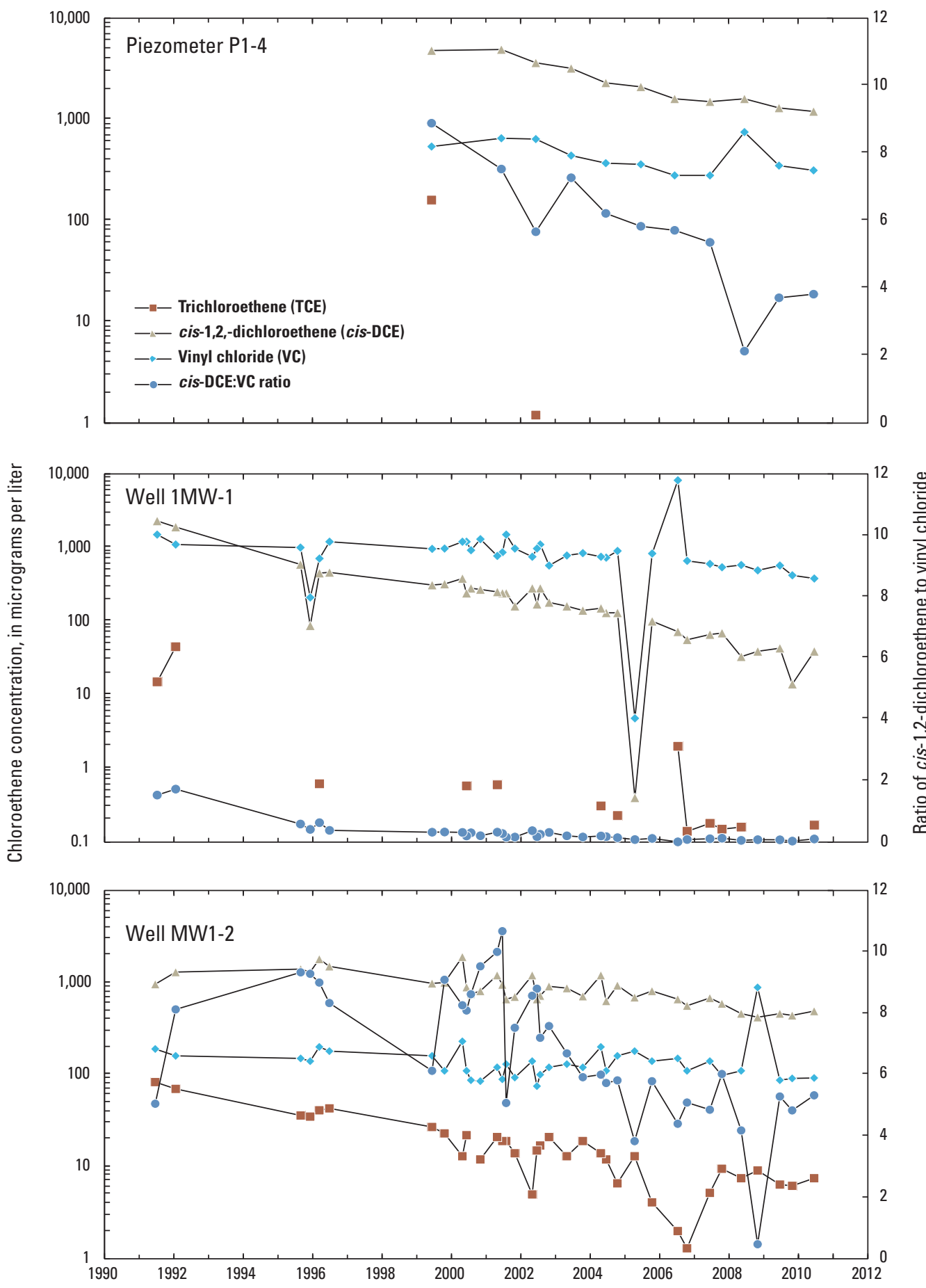

Figure 3. Chloroethene concentration and ratio of cis-1,2-dichlorethene to vinyl chloride concentrations at northern plantation wells 1MW-1, MW1-2, and piezometer P1-4 at Operable Unit 1, Naval Undersea Warfare Center, Division Keyport, Washington, 1991-2010. 


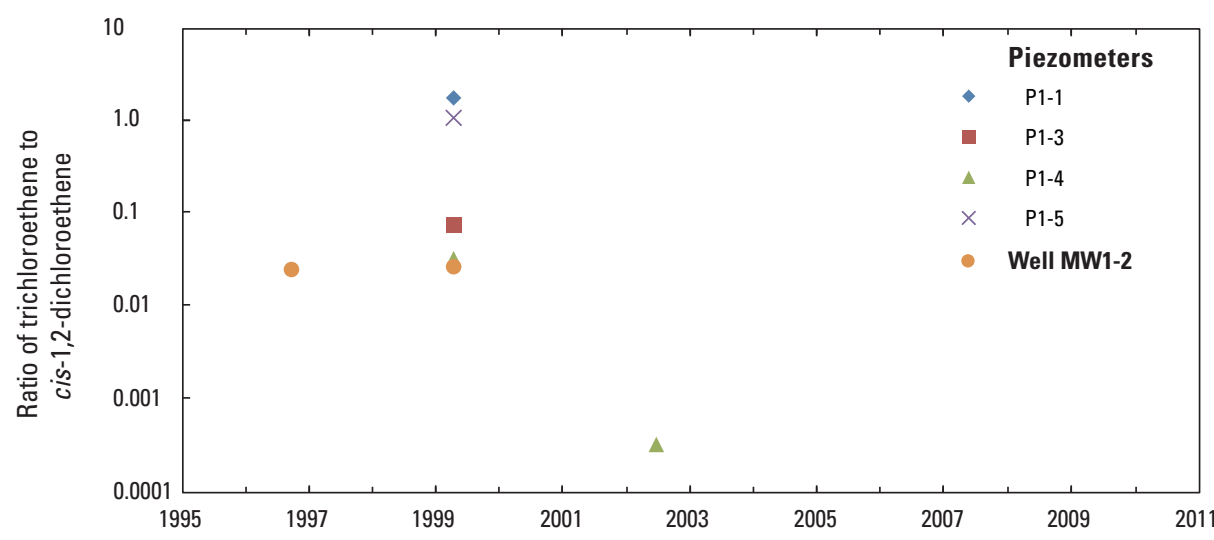

Figure 4. Ratio of trichlorethene to cis-1,2-dichlorethene concentrations at northern plantation wells and piezometers at Operable Unit 1, Naval Undersea Warfare Center, Division Keyport, Washington, 1996-2010.

\section{Southern Plantation and Adjacent Marsh}

Changes in chloroethene concentrations were highly variable in samples from the southern plantation. In general, chloroethene concentrations at most sampling sites in the northern part of the southern plantation (wells MW1-5, MW1-16, and piezometers P1-6, P1-8, and P1-10) decreased over the periods of record (fig. 5) with the exception of piezometer P1-6, where chloroethene concentrations have remained high. Piezometer P1-6 is located within the middle of the contaminant plume, which could explain no consistent trends of increasing or decreasing CVOC concentrations. However, chloroethene concentrations at sites in the southern part of the southern plantation (well MW1-4, and piezometers P1-7 and P1-9) remained high with no consistent downward trend (fig. 6).

Dilution due to increased recharge, presumably following pavement removal in 1999, combined with biodegradation are the likely causes of the observed downward trends in chloroethene concentrations in the northern half of the southern plantation (Dinicola, 2006). From prior to 1999 to 2010, chloroethene concentrations in wells MW1-5 and MW1-16 and piezometers P1-8 and P1-10 decreased up to three orders of magnitude (fig. 5).

Trends in cis-DCE:VC ratios (fig. 5) and TCE:cis-DCE ratios (fig. 7) do not clearly indicate continued reductive dechlorination of cis-DCE or TCE in the northern half of the southern plantation. The reductive dechlorination of VC is reliably indicated by ethane plus ethene concentrations as high as $613 \mu \mathrm{g} / \mathrm{L}$ in a sample from piezometer P1-6 in 2010 (table 4). A likely explanation of conditions in the northern part of the southern plantation is that biodegradation of all chloroethenes continued, but that a continuing source of dissolved TCE from residual non-aqueous phase contaminants is present (Dinicola, 2006). Such a source is suggested by TCE concentrations that increased in piezometer P1-10 from $250 \mu \mathrm{g} / \mathrm{L}$ in 2009 to $4,130 \mu \mathrm{g} / \mathrm{L}$ in 2010 (fig. 5, table 4). As was noted for the northern plantation, microbial oxidation of VC (and to a lesser extent cis-DCE) in the southern plantation also may be occurring in the iron- and manganese-reducing parts of the aquifer, but no unique diagnostic byproducts reliably indicate that process.

Chloroethene concentrations in the southern part of the southern plantation have been exceptionally high, with no consistent trend (fig. 6). Modest but inconsistent downward trends in TCE:cis-DCE (fig. 7) and cis-DCE:VC (fig. 6) ratios were observed at piezometers P1-7 and P1-9, indicating continued reductive dechlorination of TCE and cis-DCE, but trends in those same ratios were generally increasing in well MW1-4. Reductive dechlorination of vinyl chloride to non-chlorinated end products was indicated by ethane plus ethene concentrations of $690 \mu \mathrm{g} / \mathrm{L}$ in a sample from piezometer P1-7 (table 4). Again, a likely explanation for these data is that reductive dechlorination of all chloroethenes is ongoing, but that a continuing persistent source of dissolved TCE may be present. 

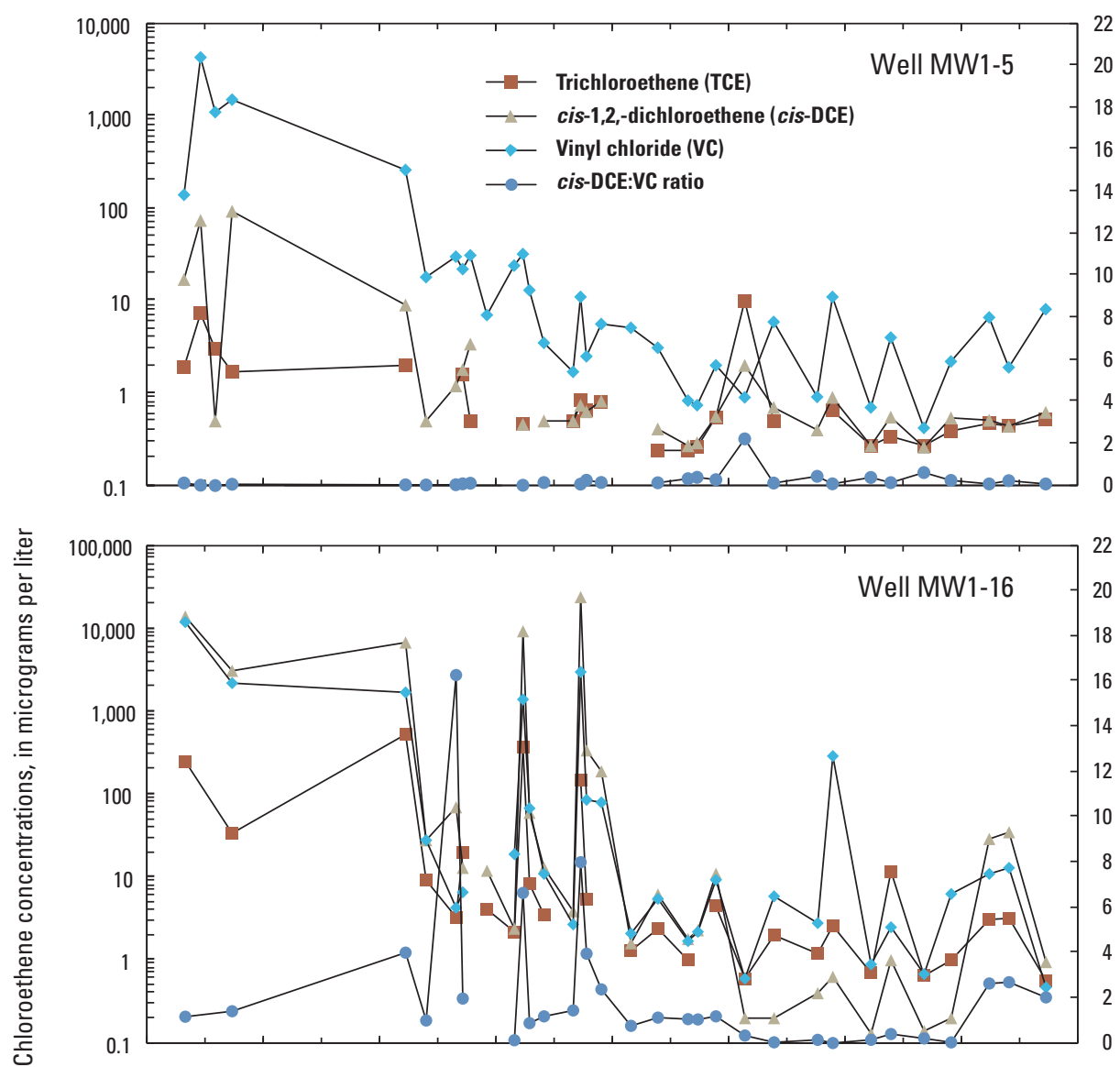

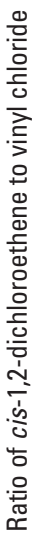

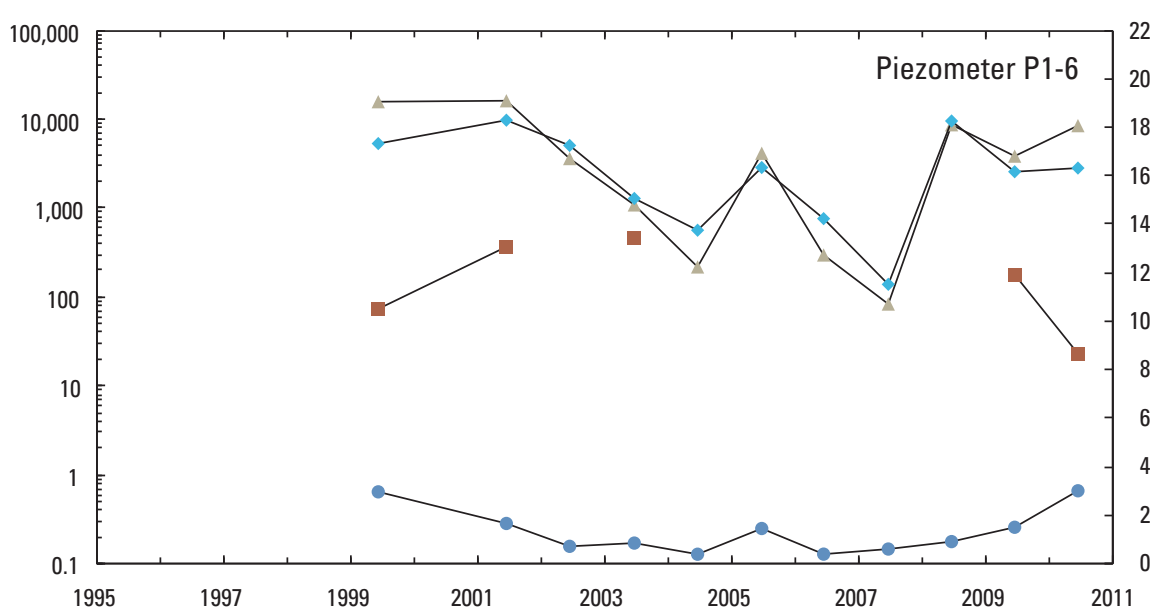

Figure 5. Chloroethene concentration and ratio of cis-1,2-dichlorethene to vinyl chloride concentrations at southern plantation wells MW1-5 and MW1-16 and piezometers P1-6, P1-8, and P1-10 at Operable Unit 1, Naval Undersea Warfare Center, Division Keyport, Washington, 1991-2010. 


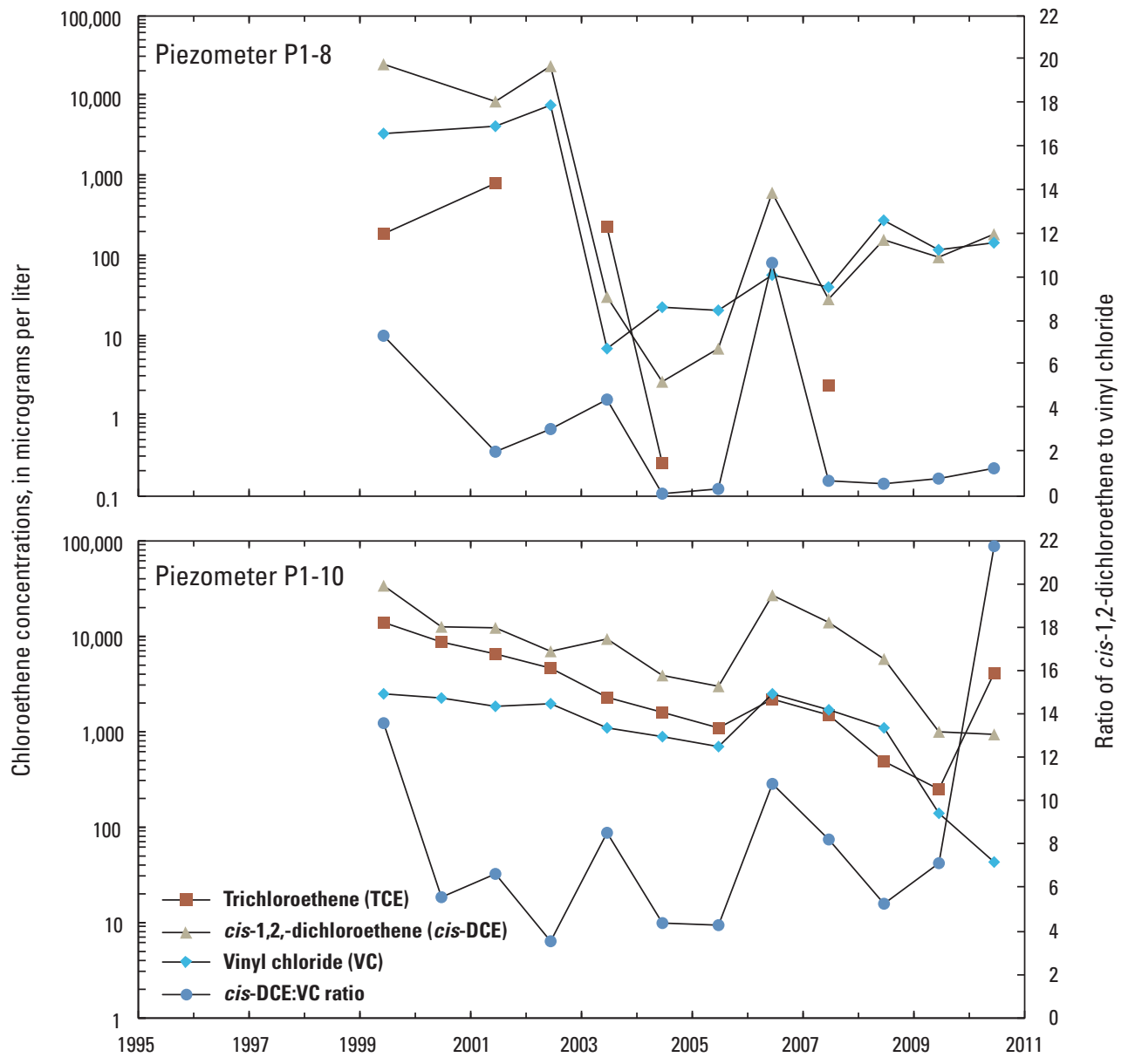

Figure 5. Continued. 

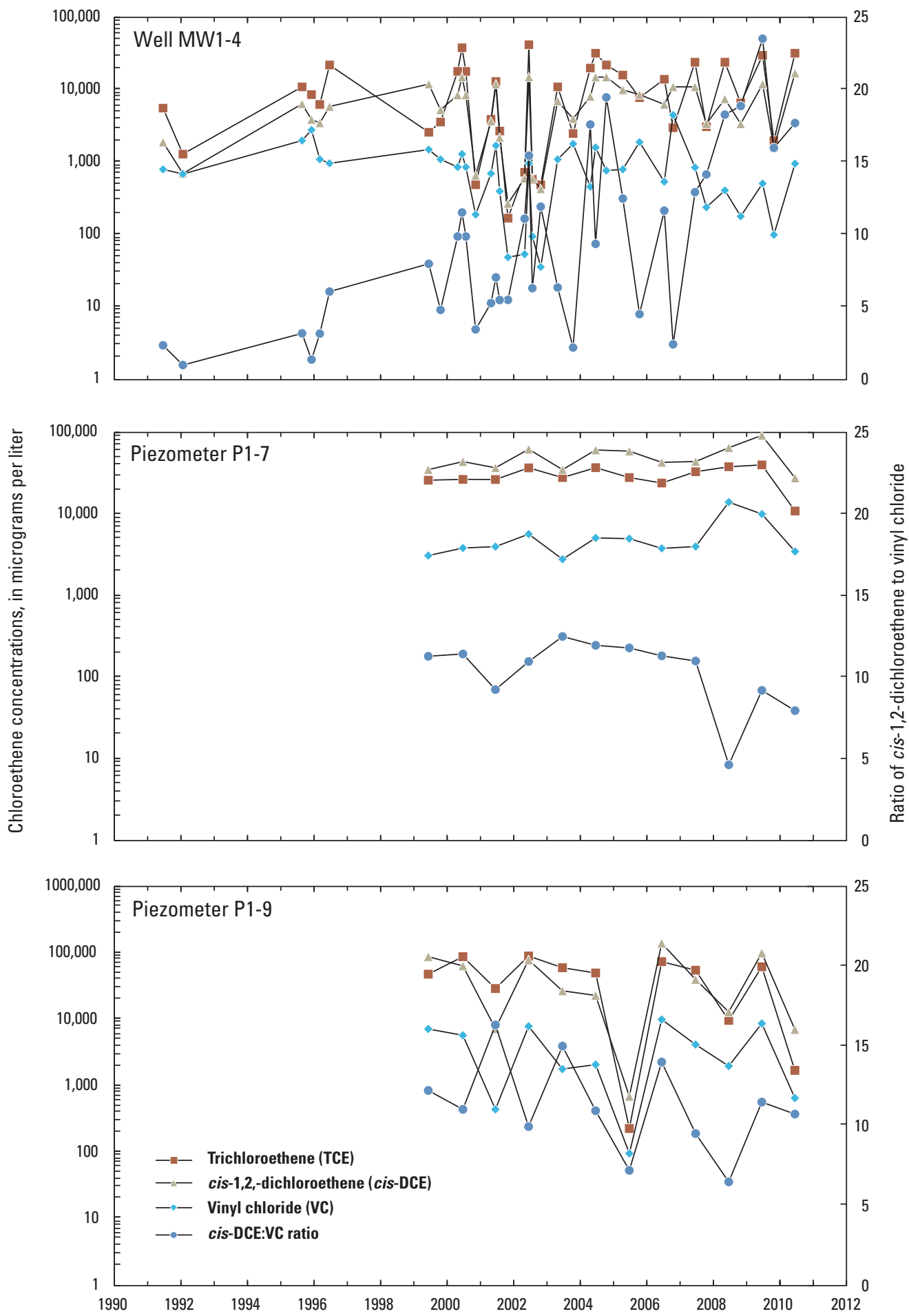

Figure 6. Chloroethene concentration and ratio of cis-1,2-dichlorethene to vinyl chloride concentrations at southern plantation well MW1-4 and piezometers P1-7 and P1-9 at Operable Unit 1, Naval Undersea Warfare Center, Division Keyport, Washington, 1991-2010. 


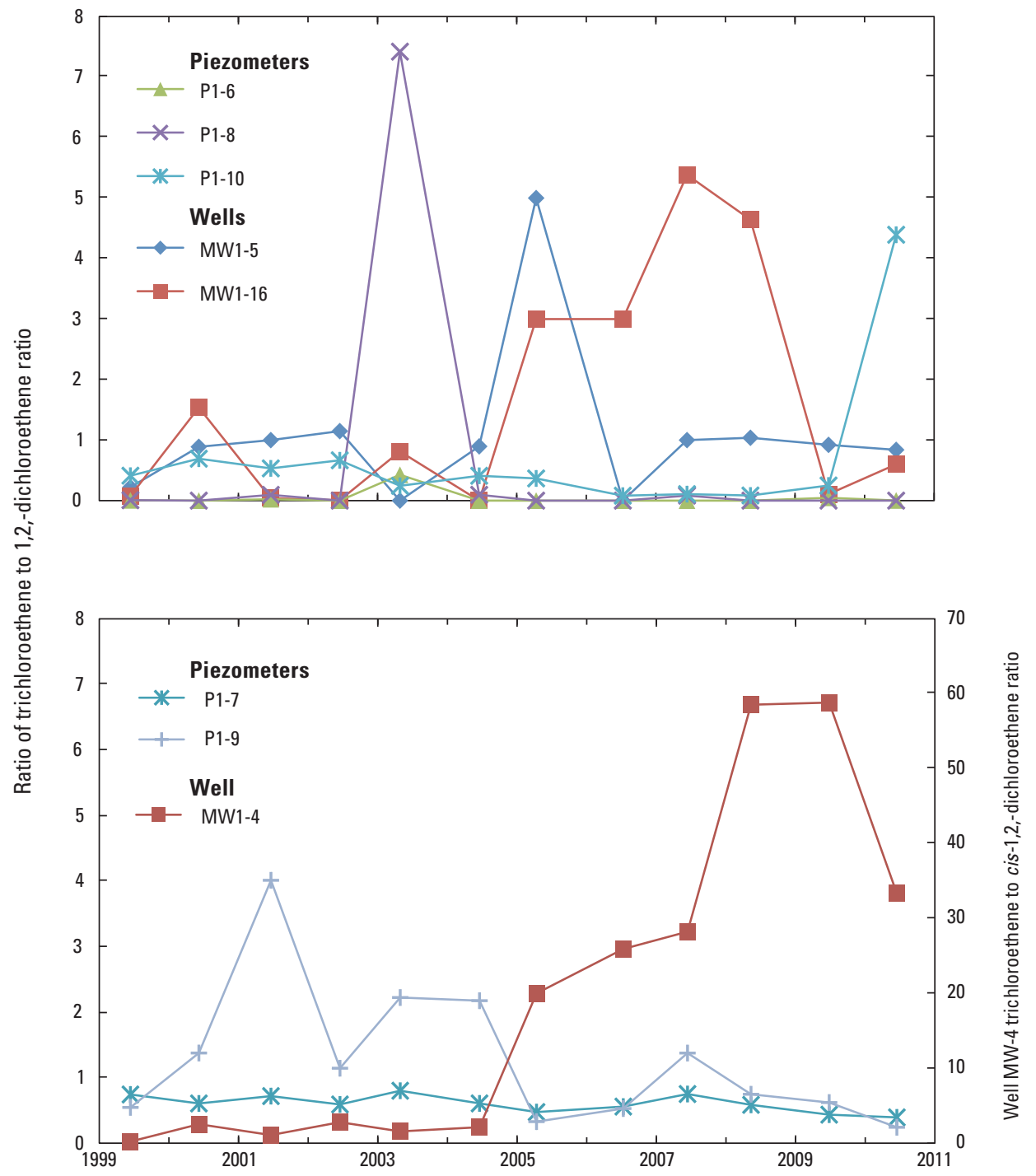

Figure 7. Ratio of trichloroethene to cis-1,2-dichlorethene concentrations at southern plantation wells and piezometers at Operable Unit 1, Naval Undersea Warfare Center, Division Keyport, Washington, 1999-2010. 
Chloroethene concentrations decreased beneath the marsh near the southern plantation at 8 of the 10 passive-diffusion sampler sites between 2004 and 2010 (table 4). Total

CVOC concentrations at historically the most contaminated passive-diffusion sampler site (S-4), located about midway along the sampled stream reach, decreased from 70,300 to $10 \mu \mathrm{g} / \mathrm{L}$ (table 4, fig. 8). Total CVOC concentrations at site S-5 also decreased from 1,737 to $1.9 \mu \mathrm{g} / \mathrm{L}$. Ratios of cis-DCE:VC at sites S-4 and S-5 in the marsh decreased substantially in 2010 indicating substantial reductive dechlorination of cis-DCE in the marsh. Sample site S-5B, located about $75 \mathrm{ft}$ upstream of site $\mathrm{S}-4$, continued to have high chlorinated VOC concentrations $(8,290 \mu \mathrm{g} / \mathrm{L})$ in 2010 . The variability in concentrations from samples at the marsh sites suggest a non-uniform pattern of VOC migration towards the marsh creek, although it is likely that the sampling method itself (buried diffusion samplers) adds some variability to the interannual results. Chloroethene concentrations in marsh surface water were measured at least twice per year by the U.S. Navy at site MA-12, just upgradient of the marsh pond, with no consistent trends but substantial variability in chloroethene concentrations (fig. 9).

In general, the trend for the entire southern plantation is decreasing chloroethene concentrations at the northern part of the southern plantation as a result of dilution and biodegradation; and there appears to be a localized non-aqueous phase chloroethene source, likely TCE, to continue replenishing groundwater contamination. Biodegradation is active in the southern part of the southern plantation, but chloroethene concentrations did not consistently decrease. A more substantial amount of non-aqueous phase chloroethene source appears to continue replenishing groundwater contamination in the southern part of the southern plantation.

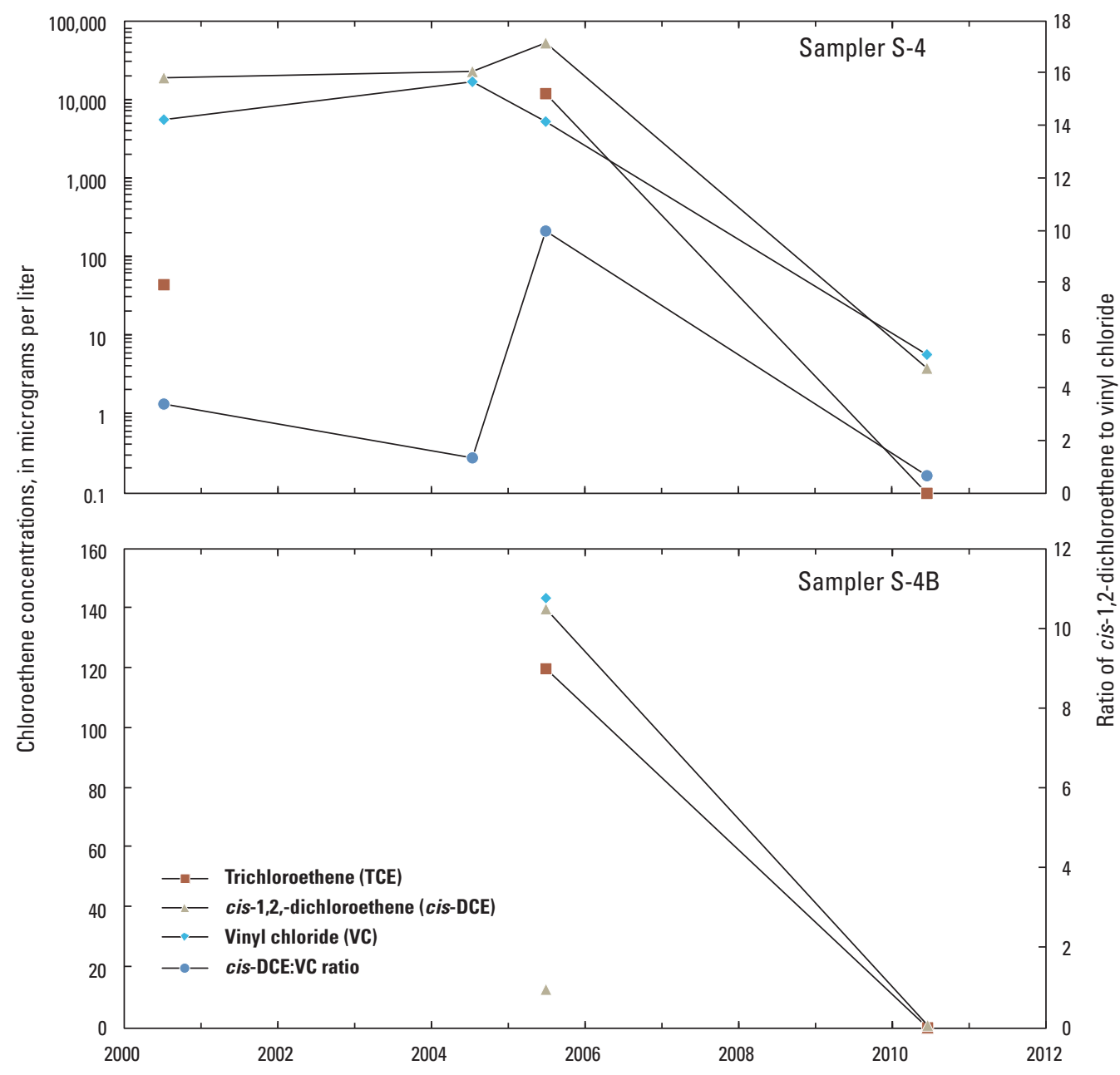

Figure 8. Chloroethene concentration and ratio of cis-1,2-dichlorethene to vinyl chloride concentrations at marsh passive-diffusion sampler sites S-4, S4-B, S-5, and S5-B at Operable Unit 1, Naval Undersea Warfare Center, Division Keyport, Washington, 2000-2010. 


\section{Intermediate Aquifer}

TCE concentrations measured in the intermediate aquifer near the downgradient margin of the landfill at wells MW1-25 and MW1-28 decreased inconsistently between 2002 and 2010 (fig. 10). Concentrations of cis-DCE and VC measured in those wells increased slightly between 1996 and 2000, but from 2001 to 2010, concentrations have stabilized. Farther downgradient in the intermediate aquifer beneath the Highway 308 causeway (wells MW1-38 and MW1-39), TCE has never been detected (table 4). Concentrations of cis-DCE and VC less than or equal to $3 \mu \mathrm{g} / \mathrm{L}$ were consistently detected in the shallower of these adjacent intermediate aquifer well (MW1-39) with no consistent trend in those concentrations.

Biodegradation of chloroethenes in the most contaminated part of the intermediate aquifer (represented by wells MW1-25 and MW1-28) was uncertain based on the 1995-2000 data (Dinicola and others, 2002). However, data through 2010 reliably indicate that some reductive dechlorination in the intermediate aquifer occurred. In addition to decreases in TCE concentrations between 2002 and 2010 , TCE:cis-DCE ratios decreased from 0.02 to 0.005 at well MW1-25 and from 0.04 to less than 0.03 at well MW1-28 during that same approximate period (table 4). These trends indicate reductive dechlorination of TCE. Reductive dechlorination of cis-DCE and VC is less certain. Ratios of cis-DCE: $\mathrm{VC}$ were either stable or increased during 1996-2008 (fig. 10) due to relatively stable VC concentrations. Ethane plus ethene concentrations ranging from 43 to $51 \mu \mathrm{g} / \mathrm{L}$ at wells MW1-25 and MW1-28 in 2010 are evidence for reductive dechlorination of VC (table 4), but concentrations were low compared to many upper aquifer sites. Together, the data indicate that some, but not substantial, biodegradation is occurring in the intermediate aquifer. Data from the contaminated well at Highway 308 (MW1-39) neither support nor refute ongoing biodegradation. VC concentrations during 2004-2010 ranged from 1.0 to $3 \mu \mathrm{g} / \mathrm{L}$, and cis-DCE concentrations ranged from 0.30 and $0.6 \mu \mathrm{g} / \mathrm{L}$ (table 4).

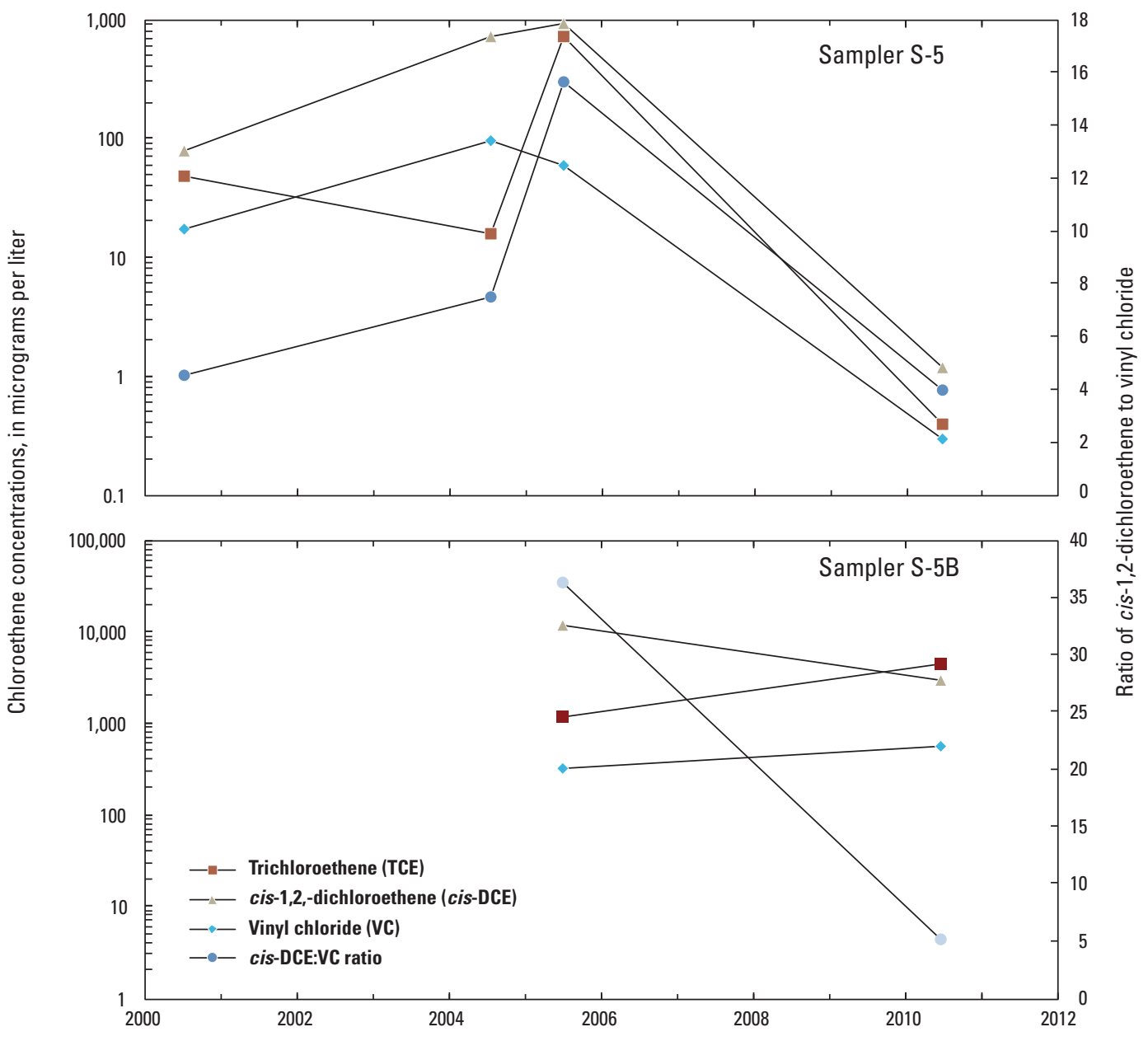

Figure 8. Continued. 


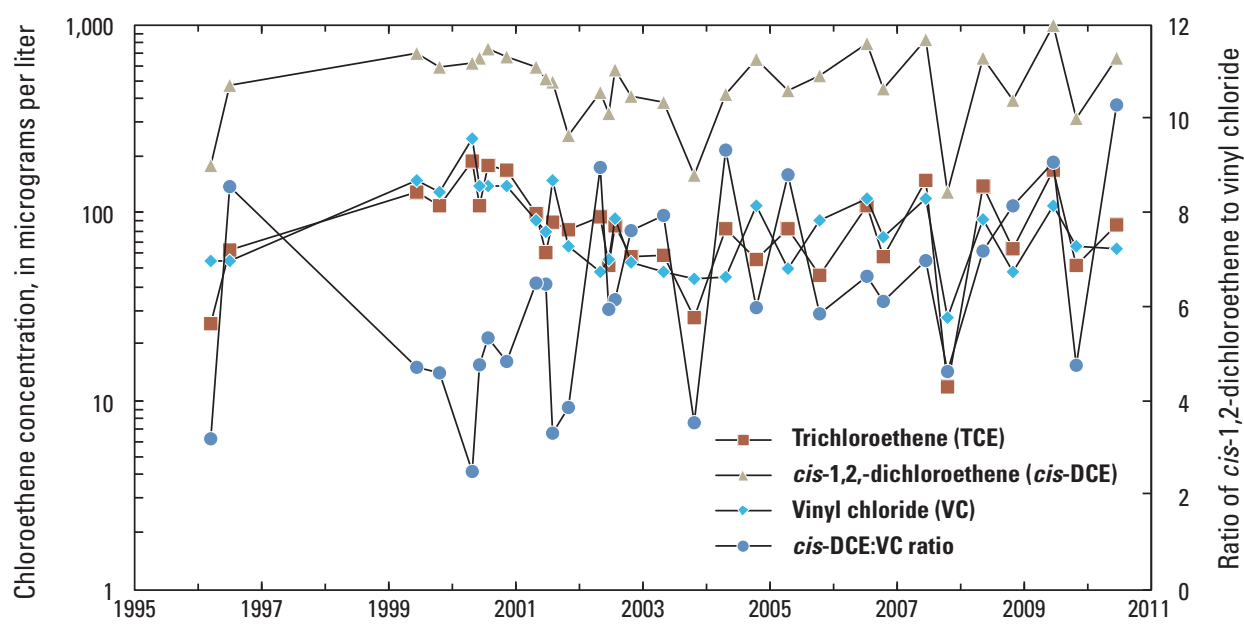

Figure 9. Chloroethene concentration and ratio of cis-1,2-dichlorethene to vinyl chloride concentrations at surface water site MA-12 at Operable Unit 1, Naval Undersea Warfare Center, Division Keyport, Washington, 1991-2010.

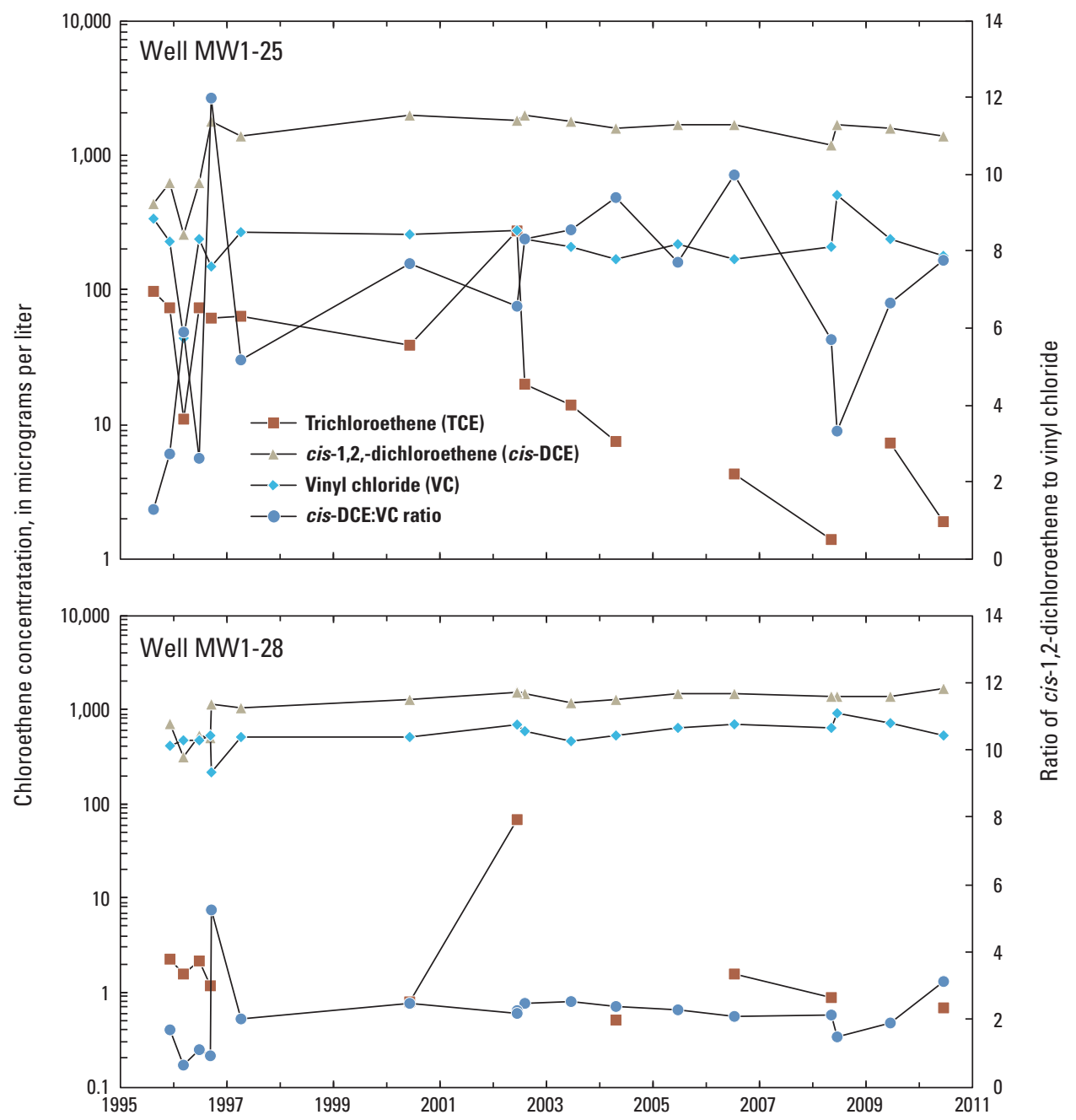

Figure 10. Chloroethene concentration and ratio of cis-1,2-dichloroethene to vinyl chloride concentrations at intermediate aquifer wells MW1-25 and MW1-28 at Operable Unit 1, Naval Undersea Warfare Center, Division Keyport, Washington, 1995-2010. 


\section{Chloroethene Mass Degradation Rates and Discharge to Surface Water}

The rates at which the chloroethene mass beneath the southern plantation at OU 1 was degraded in groundwater in the upper aquifer or was discharged to surface water were estimated using 2010 data and compared to estimates made using 1999-2000, 2004, and 2005 data. Rates were calculated according to a flux-based approach that estimates the flux of chloroethenes across two parallel transects oriented perpendicular to groundwater flow direction in the upper aquifer (fig. 11). The upgradient (landfill) transect follows the western and southern margin of the landfill, and the downgradient (marsh) transect follows the creek and pond in the adjacent marsh. The difference in chloroethene fluxes estimated for the two transects is an estimate of the mass of chloroethenes degraded in groundwater over a given duration. The mass of non-dissolved chloroethenes in the landfill (non-aqueous phase liquids) is unknown, so calculations considered only the mass of the dissolved contaminants.

Previously reported chloroethene fluxes for 1999-2000 and 2004 indicated nearly all TCE and DCE (including both cis- and trans- isomers) flux to the marsh was from the southern plantation (Dinicola, 2006). Thus, passive-diffusion data were collected only for the south sub-transect sites during 2005 and 2010, and corresponding fluxes were calculated only for the south sub-transect. The upgradient south subtransect is bounded by well MW1-5 to the northwest and well MW1-4 to the southeast, as indicated in figure 11. The downgradient south sub-transect is an approximately $300-\mathrm{ft}$ long reach of Marsh creek bounded by the passive-diffusion sampler sites S-1 and S-6. Chloroethene fluxes were calculated by multiplying estimated groundwater fluxes by measured chloroethene concentrations in wells or passive-diffusion samplers on the transect. Groundwater fluxes across each landfill sub-transect were estimated by URS Consultants Inc. (1997b) using measured or estimate transmissivity and hydraulic gradient data. Groundwater fluxes across corresponding marsh sub-transect were assumed to be the same as those estimated for the landfill sub-transect, and all groundwater discharged to marsh surface water immediately after passing the marsh transect. Measured chloroethene concentrations at sample sites along the sub-transect were proportionally weighted according to distance represented by each site to calculate average concentrations for the sub-transect. For 2005 and 2010, data from four additional passive-diffusion sampler sites (S-2B, S-3B, S-4B, and S-5B) were included in the proportional weighting.

The chloroethene mass degraded in groundwater per day beneath the southern plantation was calculated as the difference between fluxes across the south landfill sub-transect and across the south marsh sub-transect. Calculations for
DCE (including both cis- and trans-isomers) assumed that the mass of degraded TCE resulted in the formation of a molar equivalent amount of DCE through reductive dechlorination, and the calculations for $\mathrm{VC}$ assumed that the mass of degraded DCE resulted in the formation of a molar equivalent amount of VC through reductive dechlorination. The amount of PCE available in the landfill to degrade into TCE was considered negligible. The rate of chloroethene discharge to surface water in the southern marsh was assumed to be equal to the chloroethene flux calculated for the south marsh sub-transect. Rates calculated using measured chloroethene data collected in 2005 and 2010 were compared to previously reported rates for the south sub-transect only for 1999-2000 and 2004 (Dinicola, 2006).

Dinicola (2006) explains in detail the underlying assumptions and rationale in calculating the chloroethene flux from the upper aquifer to the adjacent marsh and surface water. In general, flux calculations required the following assumptions:

- Groundwater sampling sites represented conditions throughout the study area-This assumption is plausible for the dense spatial network of wells, piezometers, and passive-diffusion samplers in the study area. Vertical distribution of contaminants was not as well-defined; uniform CVOC concentrations throughout the saturated thickness of the upper aquifer were assumed.

- Groundwater flow-the supply of dissolved contaminants and contaminant degradation rates were at steady-state conditions. This is a reasonable assumption based on water-level data measured from 1996 to 2010, which indicates that overall groundwater patterns of the upper aquifer have remained constant since installing the phytoremediation plantations (URS Greiner, Inc., 2000; CH2M Hill Constructors Inc., 2004; U.S. Navy, 2010). The available synoptic water-level data are too limited to accurately assess if the hydraulic gradient driving groundwater flow changed substantially following pavement removal, but the assumption of new steady-state conditions following pavement removal is reasonable. If the magnitude of the new steady-state hydraulic gradient has changed, the magnitudes of the estimated chemical fluxes are less certain, although the differences in the estimated chemical fluxes from year to year will be reasonable.

A relatively steady supply of dissolved contaminants is indicated by stable or slowly decreasing CVOC concentrations in the most contaminated landfill wells. Steady-state contaminant degradation rates are suggested by relatively consistent redox conditions between 1996 and 2010. 


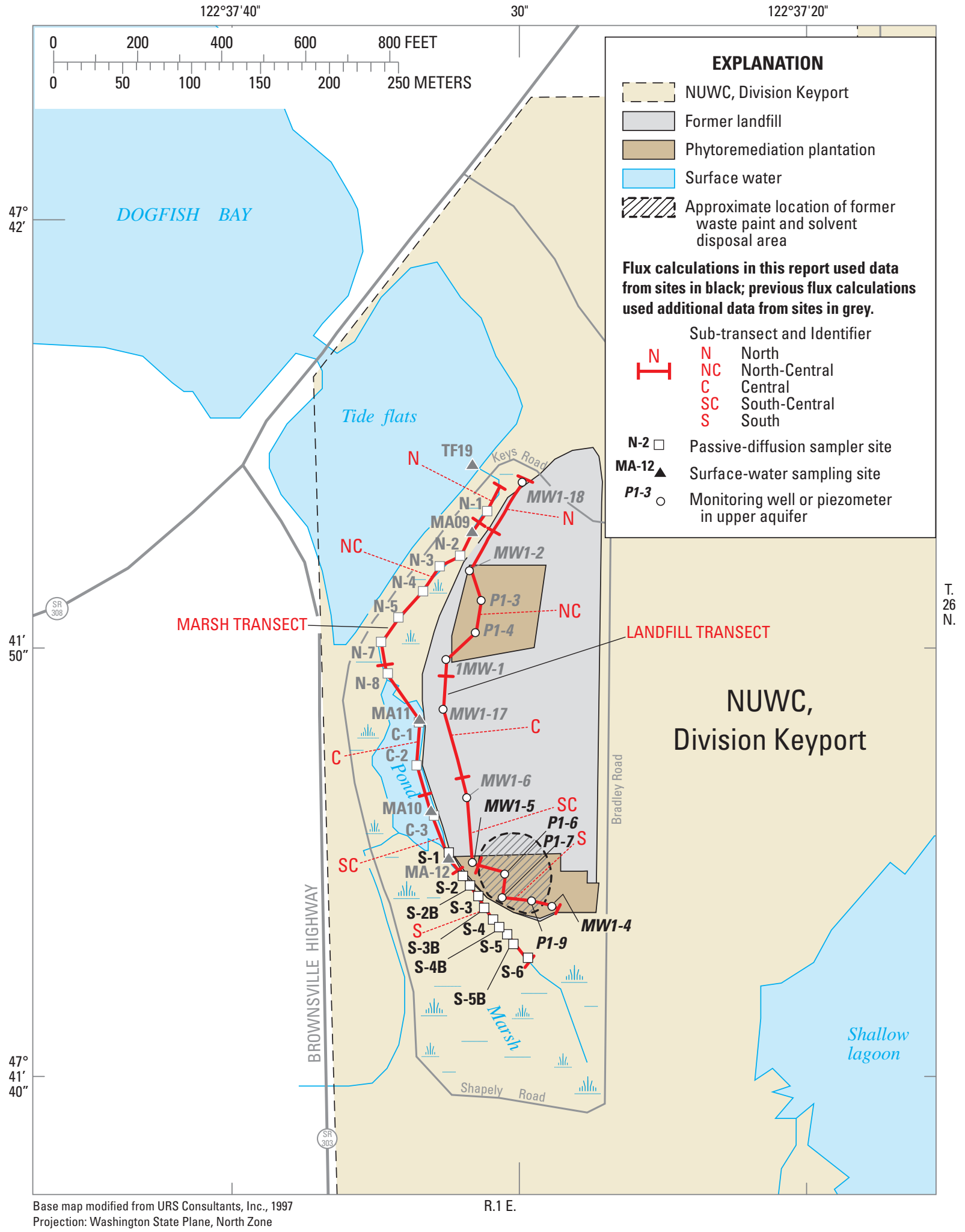

Figure 11. Transects and sub-transects where mass chloroethene fluxes were estimated for the upper aquifer at Operable Unit 1, Naval Undersea Warfare Center (NUWC), Division Keyport, Washington. 
- No substantial contaminant loss in groundwater was caused by sorption, volatilization, plant uptake beneath the phytoremediation plantations, or advective transport to the intermediate aquifer. Volatilization of chemicals from groundwater is greatly constrained by the rate of vapor transport upward, although the unsaturated zone, and therefore probably were minimal. Initially sorption losses may have been significant in the organic-rich marsh sediments, but contaminants flowed through these sediments for decades, therefore, the bulk of sorption capacity probably was filled long ago. Contaminant uptake from plants beneath the plantations was detected but did not indicate that contaminants were drawn out of the saturated zone (URS Greiner, Inc., 2002). Most of the advective transport of contaminants from the upper to the intermediate aquifer likely occurs upgradient of the landfill transect, so that advective transport will not affect the mass degradation calculations (URS Consultants, Inc., 1997a).

Flux estimates based on 2010 data indicate that most dissolved-phase chloroethene mass in the upper aquifer beneath the southern landfill was degraded before it discharged to surface water (table 5) (at back of report). Of the $25 \mathrm{~g} / \mathrm{d}$ of chloroethene flux measured at the south landfill sub-transect during 2010 , only 5 percent $(1.2 \mathrm{~g} / \mathrm{d})$ migrated and discharged to surface water in the marsh; therefore, the total chloroethene flux was reduced by 95 percent due to biodegradation in the upper aquifer. Flux estimates based on 2005 data indicated that a slightly larger dissolved contaminant flux from the landfill ( $36 \mathrm{~g} / \mathrm{d}$ ) was reduced by a smaller percentage (72 percent) in the upper aquifer and resulted in more chloroethene discharged to surface water $(10 \mathrm{~g} / \mathrm{d})$ during 2005.

The chloroethene with the greatest calculated flux into marsh surface water was DCE for every year calculated except 2010. The mass degradation rates for DCE $(20 \mathrm{~g} / \mathrm{d}$ in 2010) also were the greatest, followed by VC and TCE. In 2010 , the rate of DCE degradation $(20 \mathrm{~g} / \mathrm{d})$ was greater than the flux of DCE $(15 \mathrm{~g} / \mathrm{d})$ across the landfill transect, but DCE still reached the marsh because it was continually created by reductive dechlorination of TCE. The rate of VC degradation was about seven times greater than the flux of $\mathrm{VC}$ across the landfill transect, but VC still reached the marsh because it was continually created by reductive dechlorination of DCE.

Although the mass degradation rates for the southern plantation and adjacent marsh were substantially greater during 1999-2000 compared to 2010, the rates of discharge to surface water were lower for 2010, and the chloroethene flux from the landfill to the marsh also was the lowest in 2010, indicating continued biodegradation. However, flux estimates are extremely sensitive to measured chloroethene concentrations at the few highly contaminated wells and passive-diffusion samples in and near the southern plantation. In addition, interannual variability in measured concentrations at those sites is high. Estimated mass degradation rates were exceptionally high during 1999-2000 due to the high concentrations of chloroethenes in the landfill transect. For example, at piezometer P1-9 in the southern plantation, total CVOC concentrations were $158,000 \mu \mathrm{g} / \mathrm{L}$ during June 2000 and 9,500 $\mu \mathrm{g} / \mathrm{L}$ during June 2010 (table 4). Similarly, calculated rates for chloroethene discharge to surface water were exceptionally lower in 2010 than in 2005, in large part because chloroethene concentrations substantially decreased at all diffusion sampler sites in 2010. For example, the total CVOC concentrations at site S-4 were $70,300 \mu \mathrm{g} / \mathrm{L}$ during June 2005 and $<10 \mu \mathrm{g} / \mathrm{L}$ during 2010 (table 4).

\section{Summary and Conclusions}

Geochemical and contaminant concentration data from 2001 to 2010 indicate that biodegradation of chlorinated volatile organic compounds (CVOCs) in groundwater beneath the landfill at Operable Unit 1 (OU 1) has continued. Contaminant concentrations in groundwater decreased throughout much of the site, and biodegradation is a primary cause for the decrease. However, dissolved-phase contaminant concentrations in the tens of milligrams per liter persist in a localized area in the southern part of the southern phytoremediation plantation. A residual source of non-aqueous phase liquid chloroethenes likely is present in that area, therefore biodegradation was only partly effective at reducing the dissolved-phase contaminants that are generated from that source. During 2010, chloroethenes discharging to a 300-foot reach in the southern part of the marsh decreased substantially from previous years.

No widespread changes in groundwater redox conditions were measured since 2010 that could result in either more or less efficient biodegradation. Anaerobic redox conditions have prevailed at the site, with no consistent trend developed towards either more strongly or more mildly reducing conditions. Detections of sulfide, widespread detection of methane, frequent detection of dissolved hydrogen at concentrations greater than 1 nanomolar, and presence of ethane indicated that strongly reducing conditions most favorable for reductive dechlorination of chloroethenes are present beneath much of the landfill and in the intermediate aquifer downgradient of the site. In some areas of the site, mildly reducing conditions detected are less favorable for biodegradation through reductive dechlorination, but are more favorable for microbial oxidation of vinyl chloride (VC) and cis-1,2-dichloroethene (cis-DCE). 
The 2010 concentrations of total CVOCs and chloroethenes in the upper aquifer generally were less than concentrations measured in 2005. Low concentrations were measured throughout the northern phytoremediation plantation, in most of the northern part of the southern phytoremediation plantation, and in areas outside of the plantations. CVOC concentrations for 2010 were as high as 42,300 micrograms per liter $(\mu \mathrm{g} / \mathrm{L})$ in the southern part of the southern plantation where non-aqueous phase liquids likely are present.

Chloroethene concentrations measured in the intermediate aquifer near the downgradient margin of the landfill decreased less steadily between 2005 and 2010. At the farthest downgradient (western) monitoring points beneath the Highway 308 causeway, TCE remained undetected in the intermediate aquifer, and cis-DCE and VC consistently were measured at concentrations between 0.3 and $2.7 \mu \mathrm{g} / \mathrm{L}$.

Biodegradation was a substantial cause for the downward trend in contaminant concentrations beneath the northern plantation. Continued reductive dechlorination of cis-DCE and VC was indicated, and reductive dechlorination to nonchlorinated end products was reliably indicated by ethane plus ethene concentrations as high as $143 \mu \mathrm{g} / \mathrm{L}$.

In the northern half of the southern plantation, TCE and other chloroethene concentrations decreased over time due to dilution and biodegradation. Continued reductive dechlorination of cis-DCE and VC were indicated by ethane plus ethene concentrations as high as $690 \mu \mathrm{g} / \mathrm{L}$; however attenuation of chloroethene concentrations was partially masked by a localized residual source of dissolved non-aqueous phase liquid (TCE) to groundwater.

Chloroethene concentrations in the southern part of the southern plantation have remained exceptionally high despite reliable evidence for continued reductive dechlorination of all chloroethene compounds. Data indicate a localized persistent source for dissolved TCE to groundwater. Beneath the marsh near the southern plantation, chloroethene concentrations decreased in 8 of 10 passive-diffusion sampler sites from 2004 to 2010.

Previous chloroethene flux calculations indicated that most chloroethene flux from the land fill was from the southern plantation. Therefore, flux calculations in 2010 were based on data collected from wells and passive-diffusion samplers in and near the southern plantation and indicated that most dissolved-phase chloroethene mass in the upper aquifer beneath the southern plantation is degraded before discharging to surface water in the adjacent marsh. The total chloroethene flux of 25 grams per day estimated at the landfill transect during 2010 was reduced by 95 percent due to biodegradation in the upper aquifer before discharging to surface water. Overall, biodegradation of chloroethenes in groundwater throughout OU 1 continued through 2010 and it prevents most of the mass of dissolved-phase chloroethenes in the upper aquifer beneath the landfill from discharging to surface water.

\section{Acknowledgments}

The authors thank Douglas Thelin of the Naval Facilities Engineering Command, Northwest for his guidance and funding for the continued monitoring. U.S. Geological Survey Washington, Water Science Center Staff, Stephen Cox, Greg Justin, Karen Payne, and CG Laird assisted with data collection and analysis.

\section{References Cited}

American Public Health Association, 1980, Standard methods for the examination of water and wastewater (15th ed.): Washington, D.C., American Public Health

Bradley, P.M., 2003, History and ecology of chloroethene biodegradation-A review: Bioremediation Journal, v. 7, no. 2, p. 81-109.

Bradley, P.M., Landmeyer, J.E., and Dinicola, R.S., 1998, Anaerobic oxidation of [1,2-14C] dichloroethene under Mn(IV)-reducing conditions: Applied \& Environmental Microbiology, v. 64, no. 4, p. 1560-1562.

Brenton, R.W., and Arnett, T.L., 1993, Methods of analysis by the U.S. Geological Survey National Water Quality Laboratory-Determination of dissolved organic carbon by UV-promoted persulfate oxidation and infrared spectrometry: U.S. Geological Survey Open-File Report 92-480, $12 \mathrm{p}$.

CH2M Hill Constructors, Inc., 2002, 2001 annual report Operable Unit 1, Area 1, former base landfill, Naval Undersea Warfare Center Division, Keyport, Washington: Prepared under Contract Task Order 0062 for Engineering Field Activity, Northwest, Naval Facilities Engineering Command, Poulsbo, Wash.

CH2M Hill Constructors, Inc., 2003, 2002 annual report Operable Unit 1, Area 1, former base landfill, Naval Undersea Warfare Center Division, Keyport, WashingtonPrepared under Contract Task Order 0062 for Engineering Field Activity, Northwest, Naval Facilities Engineering Command, Poulsbo, Wash.

CH2M Hill Constructors, Inc., 2004, 2003 annual report Operable Unit 1, Area 1, former base landfill, Naval Undersea Warfare Center Division, Keyport, Washington: Prepared under Contract Task Order 0062 for Engineering Field Activity, Northwest, Naval Facilities Engineering Command, Poulsbo, Wash. 
CH2M Hill Constructors, Inc., 2005, Draft 2004 annual report Operable Unit 1, Area 1, former base landfill, Naval Undersea Warfare Center Division, Keyport, Washington: Prepared under Contract Task Order 0062 for Engineering Field Activity, Northwest, Naval Facilities Engineering Command, Poulsbo, Wash.

Chapelle, F.H., 1992, Ground-water microbiology and geochemistry: John Wiley and Sons, Inc., New York, 424 p.

Chapelle, F.H., McMahon, P.B., Dubrovsky, N.M., Fujii, R.F., Oaksford, E.T., and Vroblesky, D.A., 1995, Hydrogen $\left(\mathrm{H}_{2}\right)$ concentrations as an indicator of terminal electron accepting processes (TEAP's) in diverse groundwater systems: Water Resources Research, v. 32, p. 359-371.

Chapelle, F.H., Vroblesky, D.A., Woodward, J.C., and Lovely, D.R., 1997, Practical considerations for measuring hydrogen concentrations in groundwater: Environmental Science and Technology, v. 31, no. 10, p. 2873-2877.

Christensen, T.H., Bjerg, P.L., Banwart, S.A., Jakobsen, R., Heron, G., and Albrechtsen, H.J., 2000, Characterization of redox conditions in groundwater contaminant plumes: Journal of Contaminant Hydrology, v. 45, p. 165-241.

Connor, B.F., Rose, D.L, Noriega, L.M, and Abney, S.R., 1998, Methods of analysis by the U.S. Geological Survey National Water Quality Laboratory-determination of 86 volatile organic compounds in water by gas chromatography/mass spectrometry, including detections less than reporting limits: U.S. Geological Survey OpenFile Report 97-829, 78 p.

Cozzarelli, I.M., Sulfita, J.M., Ulrich, G.A., Harris, S.H., Scholl, M.A., Schottmann, J.L., and Christenson, S., 2000, Geochemical and microbiological methods for evaluating anaerobic processes in an aquifer contaminated by landfill leachate: Environmental Science and Technology, v. 34, no. 18, p. 4025-4033.

Dinicola, R.S., 2003, Selected natural attenuation monitoring data, Operable Unit 1, Naval Undersea Warfare Center, Division Keyport, Washington, June 2001: U.S. Geological Survey Open-File Report 03-344, 17 p.

Dinicola, R.S., 2004, Selected natural attenuation monitoring data, Operable Unit 1, Naval Undersea Warfare Center, Division Keyport, Washington, June 2002: U.S. Geological Survey Open-File Report 2004-1203, 19 p.
Dinicola, R.S., 2006, Continued biodegradation of chloroethene compounds in ground water at Operable Unit 1, Naval Undersea Warfare Center, Division Keyport, Washington: U.S. Geological Scientific Investigations Report 2006-5056, 42 p.

Dinicola, R.S., Cox, S.E., Landmeyer, J.E., and Bradley, P.M., 2002, Natural attenuation of chlorinated volatile organic compounds in ground water at Operable Unit 1, Naval Undersea Weapons Center, Division Keyport, Washington: U.S. Geological Survey Water-Resources Investigations Report 02-4119, 118 p.

Dinicola, R.S., and Huffman, R.L., 2004, Selected natural attenuation monitoring data, Operable Unit 1, Naval Undersea Warfare Center, Division Keyport, Washington, June 2003: U.S. Geological Survey Open-File Report 2004-1330, 19 p.

Dinicola, R.S., and Huffman, R.L., 2006, Selected natural attenuation monitoring data, Operable Unit 1, Naval Undersea Warfare Center, Division Keyport, Washington, June 2005: U.S. Geological Survey Open-File Report 2006-1374, 27 p.

Dinicola, R.S., and Huffman, R.L., 2007, Selected natural attenuation monitoring data, Operable Unit 1, Naval Undersea Warfare Center, Division Keyport, Washington, June 2006: U.S. Geological Survey Open-File Report 2007-1730, 28 p.

Dinicola, R.S., and Huffman, R.L., 2009, Selected natural attenuation monitoring data, Operable Unit 1, Naval Undersea Warfare Center, Division Keyport, Washington, 2007 and 2008: U.S. Geological Survey Open-File Report 2009-1141, 42 p.

Fishman, M.J., ed., 1993, Methods of analysis by the U.S. Geological Survey National Water Quality LaboratoryDetermination of inorganic and organic constituents in water and fluvial sediments: U.S. Geological Survey Open-File Report 93-125, 217 p.

Fishman, M.J., and Friedman, L.C., 1989, Methods for determination of inorganic substances in water and fluvial sediments: U.S. Geological Survey Techniques of WaterResources Investigations, book 5, chap. A1, 545 p.

Hach Company, 1998, DR/2010 Spectrophotometer Procedures Manual: Loveland, Colo., Hach Company. 
Huffman, R.L., and Dinicola, R.S. 2011, Groundwater geochemical and selected volatile organic compound data, Operable Unit 1, Naval Undersea Warfare Center, Division Keyport, Washington, June 2009: U.S. Geological Survey Data Series Report 644, 38 p.

Kampbell, D.H., and Vandergrift, S.A., 1998, Analysis of dissolved methane, ethane, ethenes, and propanes: Environmental Science and Technology, v. 23. no. 8, p. $965-969$.

Lovely, D.R., Chappelle, F.H., and Woodward, J.C., 1994, Use of dissolved $\mathrm{H}_{2}$ concentrations to determine distribution of micorbially catalyzed redox reactions in anoxic groundwater: Environmental Science and Technology, v. 28, p. 1205-1210.

Lovely, D.R., and Goodwin, S., 1988, Hydrogen concentrations as an indicator of the predominant terminal electron-accepting reactions in aquatic sediments: Geochimica et Cosmochimica Acta, v. 52, p. 2993-3003.

U.S. Geological Survey, 2011, Water quality samples for Washington: National Water Information System Web interface, accessed November 8, 2011, at http://nwis. waterdata.usgs.gov/wa/nwis/qwdat.
URS Consultants, Inc.,1997a, Final summary data assessment report for Operable Unit 1, Naval Undersea Warfare Center, Division Keyport, Washington: Seattle, Wash., prepared under contract Task Order 0189 for Engineering Field Activity, Northwest, Naval Facilities Engineering Command, Poulsbo, Wash., 3 volumes.

URS Consultants, Inc.,1997b, Final focused feasibility study for Operable Unit 1, Naval Undersea Warfare Center, Division Keyport, Washington: Prepared under contract Task Order 0189 for Engineering Field Activity, Northwest, Naval Facilities Engineering Command, Poulsbo, Wash., 3 volumes.

URS Consultants, Inc., 1998, Final record of decision for Operable Unit 1 Naval Undersea Warfare Center Division Keyport, Washington: Prepared by URS Consultants, Seattle, Wash., for Engineering Field Activity, Northwest, Naval Facilities Engineering Command, Poulsbo, Wash., $111 \mathrm{p}$.

URS Greiner, Inc., 1999, Phytoremediation closure report for Operable Unit 1, Naval Undersea Warfare Center, Division Keyport, Washington: Prepared under Contract Task Order 0189 for Engineering Field Activity, Northwest, Naval Facilities Engineering Command, Poulsbo, Wash. 
URS Greiner, Inc., 2000, Phytoremediation status report, May-July 1999, Operable Unit 1, Naval Undersea Warfare Center, Division Keyport, Washington: Prepared under CLEAN Contract No. N62474-89-D-9295 for Engineering Field Activity, Northwest, Naval Facilities Engineering Command, Poulsbo, Wash.

URS Greiner, Inc., 2002, Phytoremediation status report, JulySeptember 2002, Operable Unit 1, Naval Undersea Warfare Center, Division Keyport, Washington: Prepared under CLEAN Contract No. N62474-89-D-9295 for Engineering Field Activity, Northwest, Naval Facilities Engineering Command, Poulsbo, Wash.

U.S. Environmental Protection Agency, 1983, Methods for chemical analysis of water and wastes - Office of Research chemical analysis of water and wastes: Washington, D.C., Office of Research and Development Report EPA 600/4-79-020, $552 \mathrm{p}$.

U.S. Environmental Protection Agency, 1994, RSKSOP 175 rev. no. 2, Sample preparations and calculations for dissolved gas analysis in water samples using a GC headspace equilibration technique: U.S. Environmental Protection Agency Test Methods, Region 1, 14 p., accessed November 8, 2011, at http://www.epa.gov/region1/info/ testmethods/pdfs/RSKsop175v2.pdf.
U.S. Geological Survey, variously dated, National field manual for the collection of water-quality data: U.S. Geological Survey Techniques of Water-Resources Investigations, book 9, chaps. A1-A9, accessed June 10, 2010, at http:// pubs.water.usgs.gov/twri9A.

U.S. Navy, 2010, Final spring 2010 long-term monitoring report, Area 1 Operable Unit 1, Naval Base Kitsap Keyport, Washington: Contract No. N44255-09-D-4005, LTM/O/ Task Order 18.

Vroblesky, D.A., 2001a, User's guide for polyethylene-based passive diffusion bag sampler to obtain volatile organic compound concentrations in wells, part 1-Deployment, recovery, data interpretation, and quality control and assurance: U.S. Geological Survey Water-Resources Investigations Report 01-4060, $18 \mathrm{p}$. 
Table 2. Predominant redox conditions at wells and piezometers, and groundwater geochemical data collected at Operable Unit 1, Naval Undersea Warfare Center, Division Keyport, Washington, 1996-2010.

[All other data were published in Dinicola and others (2002), Dinicola (2003, 2004, 2006), Dinicola and Huffman (2004, 2006, 2007, 2009), and Dinicola and Huffman (2011); prior to 2000, bicarbonate was calculated from an unfiltered sample. Reported concentrations less than the detection limit usually are estimated. A range of dissolved hydrogen concentrations are shown when equilibration at a single value was never achieved. Predominant redox conditions: A, aerobic; An, anaerobic, but specific redox condition could not be determined; Fe, iron reducing; $\mathrm{M}$, methanogenic; Mn, manganese reducing; N, nitrate reducing; S, sulfate reducing. Abbreviations: nM, nanomolar; mg/L, milligram per liter; $\mu \mathrm{S} / \mathrm{cm}$, microsiemens per centimeter at 25 degrees Celsius; ORP, oxidationreduction potential; $\mathrm{mV}$, millivolt. Symbols: E, estimated value; R, data rejected (selected 1996 dissolved-oxygen data were rejected because of inadequate well purging; selected 2002 dissolved-hydrogen data were rejected because of interference from downhole instruments); <, actual value is less than value shown; >, actual value is greater than value shown; -, not analyzed]

\begin{tabular}{|c|c|c|c|c|c|c|c|c|c|c|}
\hline $\begin{array}{c}\text { Well or } \\
\text { piezometer } \\
\text { No. }\end{array}$ & $\begin{array}{c}\text { Date } \\
\text { sampled }\end{array}$ & $\begin{array}{c}\text { Predominant } \\
\text { redox } \\
\text { condition }\end{array}$ & $\begin{array}{c}\text { Dissolved } \\
\text { hydrogen } \\
\text { (nM) }\end{array}$ & $\begin{array}{c}\text { Dissolved } \\
\text { oxygen } \\
\text { (mg/L) }\end{array}$ & $\begin{array}{l}\text { Unfiltered (total) } \\
\text { organic carbon } \\
\text { (mg/L) }\end{array}$ & $\begin{array}{c}\text { Filtered } \\
\text { (dissolved) } \\
\text { organic carbon } \\
\text { (mg/L) }\end{array}$ & $\begin{array}{c}\text { Filtered } \\
\text { nitrate + nitrite } \\
\text { (mg/L as N) }\end{array}$ & $\begin{array}{c}\text { Filtered } \\
\text { manganese } \\
(\mathrm{mg} / \mathrm{L})\end{array}$ & $\begin{array}{c}\text { Filtered } \\
\text { iron (II) } \\
\text { (mg/L) }\end{array}$ & $\begin{array}{l}\text { Filtered } \\
\text { sulfate } \\
\text { (mg/L) }\end{array}$ \\
\hline \multicolumn{11}{|c|}{ Upgradient } \\
\hline \multirow[t]{8}{*}{ MW1-3 } & 06-09-99 & $\mathrm{Fe}$ & 0.8 & 0.4 & - & - & - & 0.07 & $<0.01$ & - \\
\hline & $06-20-00$ & $\mathrm{Fe}$ & .2 & .3 & 2.0 & - & 0.99 & .08 & $<.01$ & 13 \\
\hline & $06-17-03$ & A & - & 4.3 & - & 1.7 & 1.8 & .09 & .05 & 12 \\
\hline & $06-15-04$ & $\mathrm{Mn} / \mathrm{Fe}$ & .2 & .2 & - & 1.6 & - & .09 & $<.01$ & 12 \\
\hline & $06-20-05$ & $\mathrm{Mn} / \mathrm{Fe}$ & $<.1$ & .1 & - & 1.4 & 1.6 & .10 & .01 & 15 \\
\hline & $06-12-06$ & $\mathrm{Mn} / \mathrm{Fe}$ & $<.1$ & .1 & - & 1.4 & 1.6 & .11 & $<.01$ & 14 \\
\hline & $06-18-07$ & $\mathrm{~N}$ & - & .6 & - & 1.8 & 1.1 & .09 & $<.01$ & 16 \\
\hline & $06-16-08$ & $\mathrm{~N}$ & - & 6 & - & 2.0 & 1.1 & .10 & $<.01$ & 18 \\
\hline \multirow{10}{*}{ MW1-20 } & 06-13-01 & $\mathrm{S}$ & 2.1 & .2 & 3.0 & 1.4 & $<.05$ & .28 & .01 & 20 \\
\hline & $06-12-02$ & An & $>100 \mathrm{R}$ & .1 & - & 1.4 & $<.05$ & .16 & .01 & 17 \\
\hline & $06-17-03$ & $\mathrm{Fe}$ & .5 & .2 & - & 1.7 & $<.06$ & .24 & .05 & 18 \\
\hline & $06-15-04$ & $\mathrm{Mn} / \mathrm{Fe}$ & .1 & .9 & - & 1.6 & - & .23 & .03 & 18 \\
\hline & $06-20-05$ & $\mathrm{Mn} / \mathrm{Fe}$ & .1 & .4 & - & 1.5 & $<.06$ & .25 & .21 & 16 \\
\hline & $06-13-06$ & $\mathrm{Mn} / \mathrm{Fe}$ & .1 & .1 & - & 1.7 & $<.06$ & .21 & .08 & 16 \\
\hline & $06-18-07$ & $\mathrm{Mn} / \mathrm{Fe}$ & - & .2 & - & 1.8 & $<.06$ & .21 & .34 & 14 \\
\hline & $06-18-08$ & A & - & 3.4 & - & 1.5 & $<.04$ & .19 & .06 & 19 \\
\hline & $06-15-09$ & $\mathrm{Fe}$ & .1 & .3 & - & 1.6 & $<.04$ & .19 & .16 & 13 \\
\hline & 06-14-10 & $\mathrm{Fe}$ & .3 & .5 & - & 1.3 & E.02 & .06 & .05 & 18 \\
\hline \multicolumn{11}{|c|}{ Northern plantation } \\
\hline \multirow[t]{6}{*}{ 1MW-1 } & $09-17-96$ & $\mathrm{Fe}$ & 0.4 & $2.8 \mathrm{R}$ & 7.0 & - & $<0.02$ & 0.18 & 0.24 & 7.5 \\
\hline & $06-12-06$ & $\mathrm{Mn} / \mathrm{Fe}$ & $<.1$ & .2 & - & 8.5 & $<.06$ & .12 & .8 & 1.9 \\
\hline & $06-19-07$ & An & .3 & .1 & - & 6.8 & E.05 & 1.3 & .72 & 6.4 \\
\hline & $06-17-08$ & An & .2 & .2 & - & 9.6 & $<.04$ & .13 & 1.4 & 1.3 \\
\hline & $06-15-09$ & $\mathrm{Fe}$ & $<.1$ & .3 & - & 7.1 & $<.04$ & .10 & .55 & 1.4 \\
\hline & $06-14-10$ & $\mathrm{Fe}$ & .2 & .9 & & 7.5 & $<.04$ & .10 & .71 & .7 \\
\hline
\end{tabular}


Table 2. Predominant redox conditions at wells and piezometers, and groundwater geochemical data collected at Operable Unit 1, Naval Undersea Warfare Center, Division Keyport, Washington, 1996-2010.-Continued

[All other data were published in Dinicola and others (2002), Dinicola (2003, 2004, 2006), Dinicola and Huffman (2004, 2006, 2007, 2009), and Dinicola and Huffman (2011); prior to 2000, bicarbonate was calculated from an unfiltered sample. Reported concentrations less than the detection limit usually are estimated. A range of dissolved hydrogen concentrations are shown when equilibration at a single value was never achieved. Predominant redox conditions: A, aerobic; An, anaerobic, but specific redox condition could not be determined; Fe, iron reducing; $\mathrm{M}$, methanogenic; Mn, manganese reducing; N, nitrate reducing; S, sulfate reducing. Abbreviations: nM, nanomolar; mg/L, milligram per liter; $\mu \mathrm{S} / \mathrm{cm}$, microsiemens per centimeter at 25 degrees Celsius; ORP, oxidationreduction potential; mV, millivolt. Symbols: E, estimated value; R, data rejected (selected 1996 dissolved-oxygen data were rejected because of inadequate well purging; selected 2002 dissolved-hydrogen data were rejected because of interference from downhole instruments); <, actual value is less than value shown; >, actual value is greater than value shown; -, not analyzed]

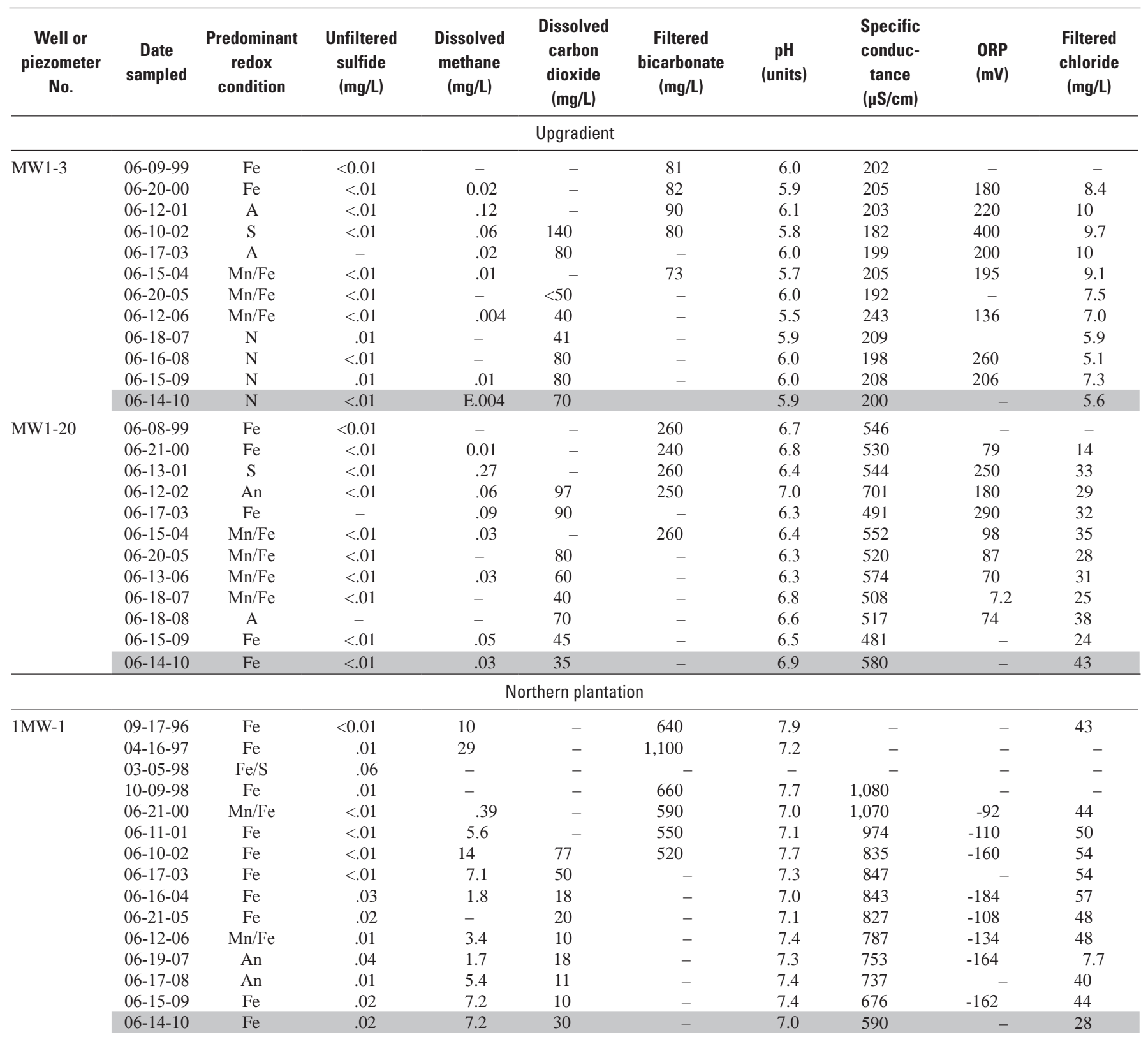


Table 2. Predominant redox conditions at wells and piezometers, and groundwater geochemical data collected at Operable Unit 1, Naval Undersea Warfare Center, Division Keyport, Washington, 1996-2010.-Continued

[All other data were published in Dinicola and others (2002), Dinicola (2003, 2004, 2006), Dinicola and Huffman (2004, 2006, 2007, 2009), and Dinicola and Huffman (2011); prior to 2000, bicarbonate was calculated from an unfiltered sample. Reported concentrations less than the detection limit usually are estimated. A range of dissolved hydrogen concentrations are shown when equilibration at a single value was never achieved. Predominant redox conditions: A, aerobic; An, anaerobic, but specific redox condition could not be determined; Fe, iron reducing; M, methanogenic; Mn, manganese reducing; N, nitrate reducing; S, sulfate reducing. Abbreviations: nM, nanomolar; mg/L, milligram per liter; $\mu \mathrm{S} / \mathrm{cm}$, microsiemens per centimeter at 25 degrees Celsius; ORP, oxidationreduction potential; mV, millivolt. Symbols: E, estimated value; R, data rejected (selected 1996 dissolved-oxygen data were rejected because of inadequate well purging; selected 2002 dissolved-hydrogen data were rejected because of interference from downhole instruments); <, actual value is less than value shown; >, actual value is greater than value shown; -, not analyzed]

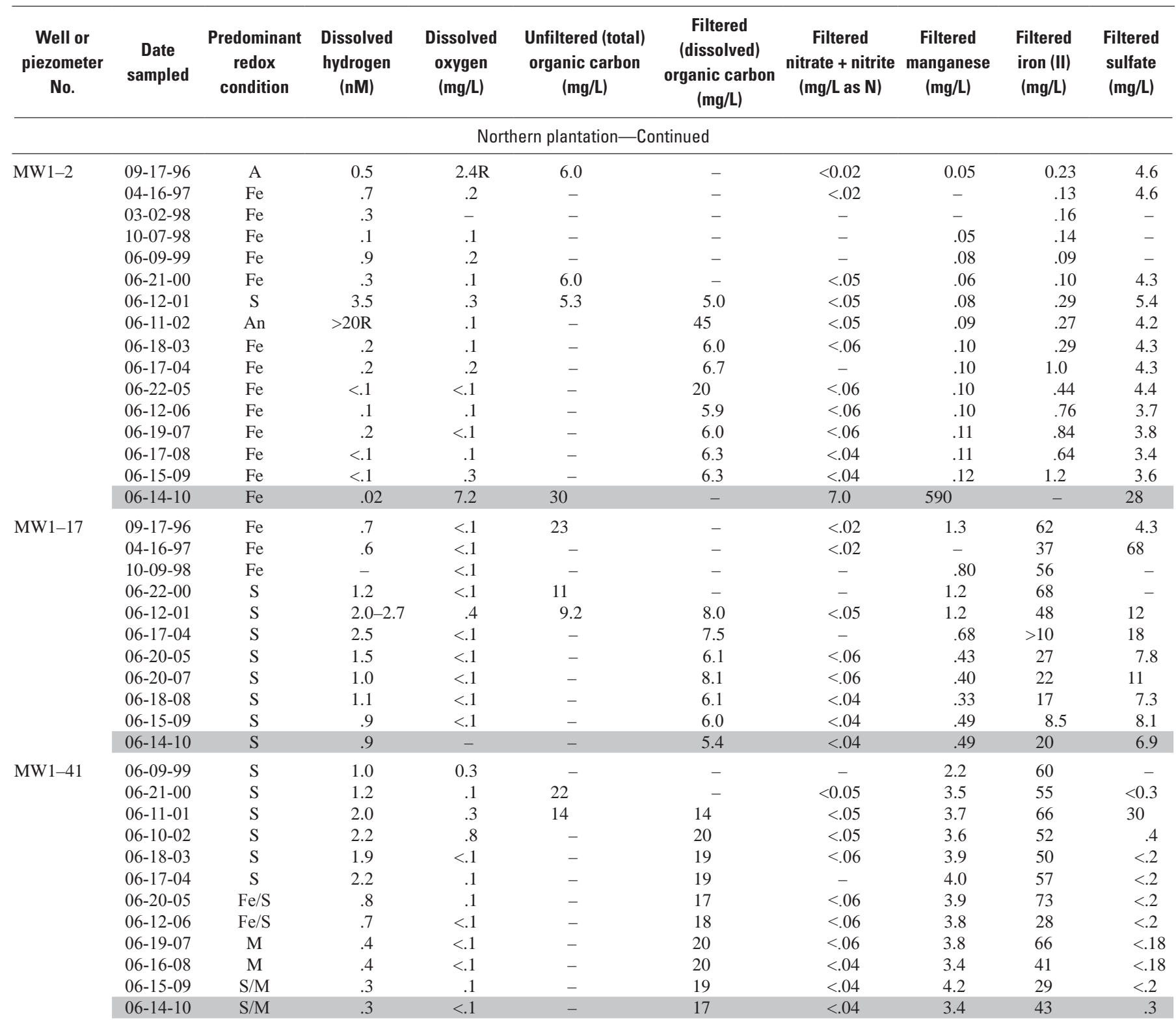


Table 2. Predominant redox conditions at wells and piezometers, and groundwater geochemical data collected at Operable Unit 1, Naval Undersea Warfare Center, Division Keyport, Washington, 1996-2010.-Continued

[All other data were published in Dinicola and others (2002), Dinicola (2003, 2004, 2006), Dinicola and Huffman (2004, 2006, 2007, 2009), and Dinicola and Huffman (2011); prior to 2000, bicarbonate was calculated from an unfiltered sample. Reported concentrations less than the detection limit usually are estimated. A range of dissolved hydrogen concentrations are shown when equilibration at a single value was never achieved. Predominant redox conditions: A, aerobic; An, anaerobic, but specific redox condition could not be determined; Fe, iron reducing; M, methanogenic; Mn, manganese reducing; N, nitrate reducing; S, sulfate reducing. Abbreviations: nM, nanomolar; $\mathrm{mg} / \mathrm{L}$, milligram per liter; $\mu \mathrm{S} / \mathrm{cm}$, microsiemens per centimeter at 25 degrees Celsius; ORP, oxidationreduction potential; mV, millivolt. Symbols: E, estimated value; R, data rejected (selected 1996 dissolved-oxygen data were rejected because of inadequate well purging; selected 2002 dissolved-hydrogen data were rejected because of interference from downhole instruments); $<$, actual value is less than value shown; >, actual value is greater than value shown; -, not analyzed]

\begin{tabular}{|c|c|c|c|c|c|c|c|c|c|c|}
\hline $\begin{array}{c}\text { Well or } \\
\text { piezometer } \\
\text { No. }\end{array}$ & $\begin{array}{c}\text { Date } \\
\text { sampled }\end{array}$ & $\begin{array}{c}\text { Predominant } \\
\text { redox } \\
\text { condition }\end{array}$ & $\begin{array}{l}\text { Unfiltered } \\
\text { sulfide } \\
\text { (mg/L) }\end{array}$ & $\begin{array}{c}\text { Dissolved } \\
\text { methane } \\
\text { (mg/L) }\end{array}$ & $\begin{array}{c}\text { Dissolved } \\
\text { carbon } \\
\text { dioxide } \\
\text { (mg/L) }\end{array}$ & $\begin{array}{c}\text { Filtered } \\
\text { bicarbonate } \\
\text { (mg/L) }\end{array}$ & $\begin{array}{c}\mathrm{pH} \\
\text { (units) }\end{array}$ & $\begin{array}{c}\text { Specific } \\
\text { conduc- } \\
\text { tance } \\
(\mu \mathrm{S} / \mathrm{cm})\end{array}$ & $\begin{array}{l}\text { ORP } \\
(\mathrm{mV})\end{array}$ & $\begin{array}{c}\text { Filtered } \\
\text { chloride } \\
\text { (mg/L) }\end{array}$ \\
\hline \multicolumn{11}{|c|}{ Northern plantation-Continued } \\
\hline \multirow[t]{9}{*}{ MW1-2 } & $09-17-96$ & A & $<0.01$ & 1.2 & - & 510 & 6.9 & - & - & 50 \\
\hline & $04-16-97$ & $\mathrm{Fe}$ & $<.01$ & 2.5 & - & 1,100 & 6.7 & - & - & - \\
\hline & 06-09-99 & $\mathrm{Fe}$ & $<.01$ & - & - & 490 & 6.8 & 901 & - & - \\
\hline & $06-21-00$ & $\mathrm{Fe}$ & $<.01$ & .04 & - & 460 & 6.8 & 870 & 37 & 36 \\
\hline & $06-12-01$ & $\mathrm{~S}$ & $<.01$ & .78 & - & 470 & 6.5 & 853 & 27 & 48 \\
\hline & $06-11-02$ & An & $<.01$ & .92 & 200 & 500 & 6.6 & 829 & 200 & 37 \\
\hline & $06-18-03$ & $\mathrm{Fe}$ & $<.01$ & .98 & 160 & - & 6.4 & 870 & 62 & 41 \\
\hline & $06-17-04$ & $\mathrm{Fe}$ & - & .33 & 50 & - & 6.6 & 858 & - & 40 \\
\hline & 06-14-10 & $\mathrm{Fe}$ & $<.01$ & .73 & 70 & - & 6.5 & 805 & - & 27 \\
\hline \multirow[t]{11}{*}{ MW1-17 } & $09-17-96$ & $\mathrm{Fe}$ & $<.01$ & 8.9 & - & 760 & 6.5 & - & - & 61 \\
\hline & $04-16-97$ & $\mathrm{Fe}$ & .02 & 23 & - & 1,200 & 6.6 & - & - & - \\
\hline & $10-09-98$ & $\mathrm{Fe}$ & .02 & - & - & 510 & 6.4 & 1,740 & - & - \\
\hline & $06-22-00$ & $\mathrm{~S}$ & .02 & 2.8 & - & 450 & 6.5 & 1,260 & -41 & 160 \\
\hline & $06-12-01$ & $\mathrm{~S}$ & .01 & 9.4 & - & 500 & 6.5 & 1,200 & -280 & 120 \\
\hline & $06-17-04$ & $\mathrm{~S}$ & - & .37 & 70 & - & 6.5 & 318 & - & 150 \\
\hline & $06-20-05$ & $\mathrm{~S}$ & .04 & - & 80 & - & 6.3 & 563 & -144 & 74 \\
\hline & $06-20-07$ & $\mathrm{~S}$ & .03 & 2.9 & 55 & - & 6.5 & 635 & -123 & 96 \\
\hline & $06-18-08$ & $\mathrm{~S}$ & .04 & 5.5 & 26 & - & 6.6 & 551 & -109 & 59 \\
\hline & $06-15-09$ & $\mathrm{~S}$ & .03 & 8.3 & 40 & - & 6.3 & 523 & -115 & 68 \\
\hline & $06-14-10$ & S & .03 & 10 & 120 & - & 6.2 & 271 & -104 & 46 \\
\hline \multirow{3}{*}{ MW1-41 } & $06-16-08$ & $\mathrm{M}$ & .01 & 9.9 & 300 & - & 6.4 & 1,240 & -93 & 11 \\
\hline & 06-15-09 & $\mathrm{S} / \mathrm{M}$ & $<.01$ & 18 & 400 & - & 6.2 & 1,200 & -99 & 16 \\
\hline & $06-14-10$ & $\mathrm{~S} / \mathrm{M}$ & .02 & 24 & $<10$ & - & 6.4 & 1,200 & - & 15 \\
\hline
\end{tabular}


Table 2. Predominant redox conditions at wells and piezometers, and groundwater geochemical data collected at Operable Unit 1, Naval Undersea Warfare Center, Division Keyport, Washington, 1996-2010.-Continued

[All other data were published in Dinicola and others (2002), Dinicola (2003, 2004, 2006), Dinicola and Huffman (2004, 2006, 2007, 2009), and Dinicola and Huffman (2011); prior to 2000, bicarbonate was calculated from an unfiltered sample. Reported concentrations less than the detection limit usually are estimated. A range of dissolved hydrogen concentrations are shown when equilibration at a single value was never achieved. Predominant redox conditions: A, aerobic; An, anaerobic, but specific redox condition could not be determined; Fe, iron reducing; M, methanogenic; Mn, manganese reducing; N, nitrate reducing; S, sulfate reducing. Abbreviations: nM, nanomolar; mg/L, milligram per liter; $\mu \mathrm{S} / \mathrm{cm}$, microsiemens per centimeter at 25 degrees Celsius; ORP, oxidationreduction potential; mV, millivolt. Symbols: E, estimated value; R, data rejected (selected 1996 dissolved-oxygen data were rejected because of inadequate well purging; selected 2002 dissolved-hydrogen data were rejected because of interference from downhole instruments); <, actual value is less than value shown; >, actual value is greater than value shown; -, not analyzed]

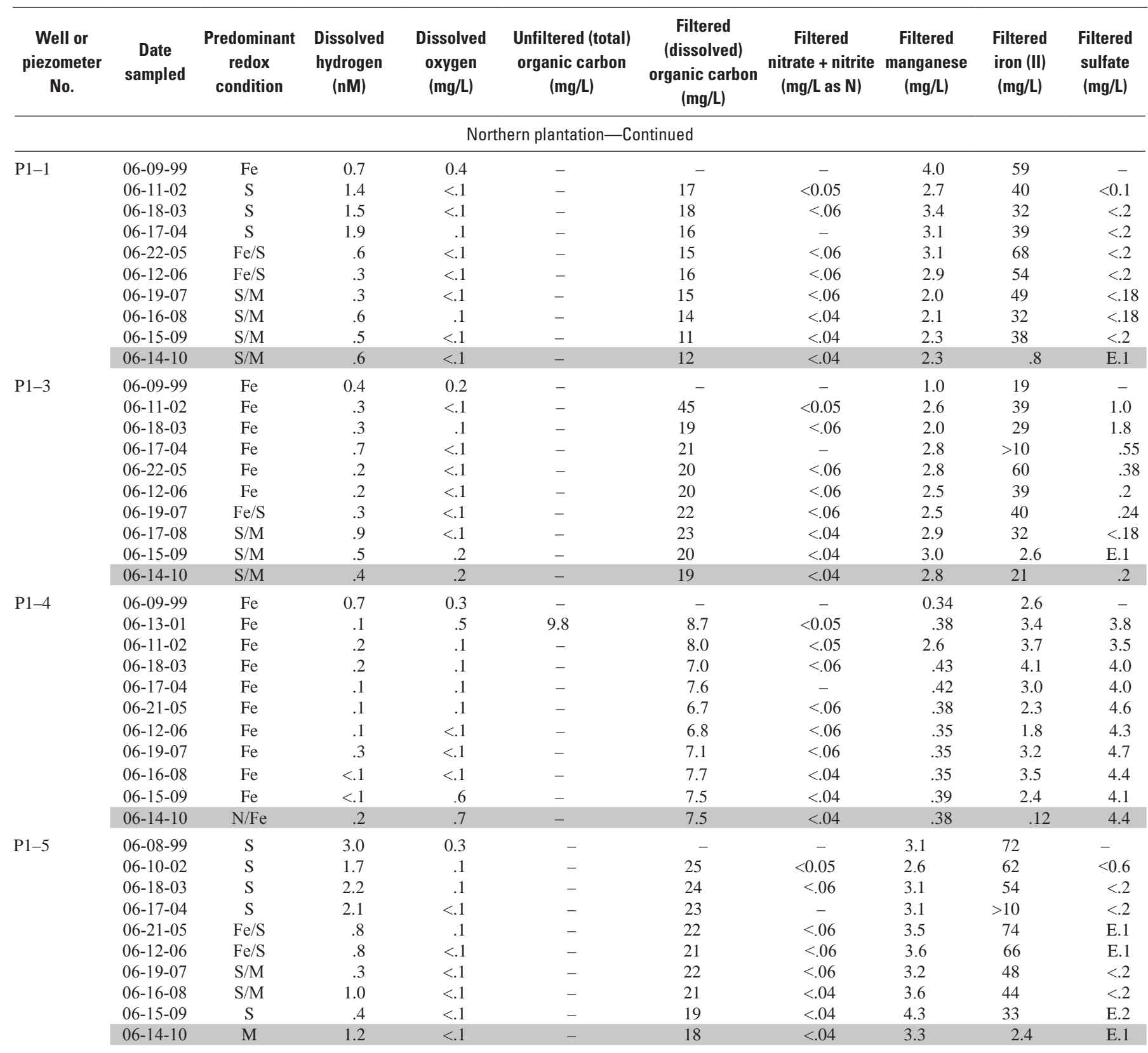


Table 2. Predominant redox conditions at wells and piezometers, and groundwater geochemical data collected at Operable Unit 1, Naval Undersea Warfare Center, Division Keyport, Washington, 1996-2010.-Continued

[All other data were published in Dinicola and others (2002), Dinicola (2003, 2004, 2006), Dinicola and Huffman (2004, 2006, 2007, 2009), and Dinicola and Huffman (2011); prior to 2000, bicarbonate was calculated from an unfiltered sample. Reported concentrations less than the detection limit usually are estimated. A range of dissolved hydrogen concentrations are shown when equilibration at a single value was never achieved. Predominant redox conditions: A, aerobic; An, anaerobic, but specific redox condition could not be determined; Fe, iron reducing; M, methanogenic; Mn, manganese reducing; N, nitrate reducing; S, sulfate reducing. Abbreviations: nM, nanomolar; mg/L, milligram per liter; $\mu \mathrm{S} / \mathrm{cm}$, microsiemens per centimeter at 25 degrees Celsius; ORP, oxidationreduction potential; mV, millivolt. Symbols: E, estimated value; R, data rejected (selected 1996 dissolved-oxygen data were rejected because of inadequate well purging; selected 2002 dissolved-hydrogen data were rejected because of interference from downhole instruments); $<$, actual value is less than value shown; >, actual value is greater than value shown; -, not analyzed]

\begin{tabular}{|c|c|c|c|c|c|c|c|c|c|c|}
\hline $\begin{array}{c}\text { Well or } \\
\text { piezometer } \\
\text { No. }\end{array}$ & $\begin{array}{c}\text { Date } \\
\text { sampled }\end{array}$ & $\begin{array}{l}\text { Predominant } \\
\text { redox } \\
\text { condition }\end{array}$ & $\begin{array}{l}\text { Unfiltered } \\
\text { sulfide } \\
\text { (mg/L) }\end{array}$ & $\begin{array}{c}\text { Dissolved } \\
\text { methane } \\
\text { (mg/L) }\end{array}$ & $\begin{array}{c}\text { Dissolved } \\
\text { carbon } \\
\text { dioxide } \\
\text { (mg/L) }\end{array}$ & $\begin{array}{c}\text { Filtered } \\
\text { bicarbonate } \\
\text { (mg/L) }\end{array}$ & $\begin{array}{c}\mathrm{pH} \\
\text { (units) }\end{array}$ & $\begin{array}{c}\text { Specific } \\
\text { conduc- } \\
\text { tance } \\
(\mu \mathrm{S} / \mathrm{cm})\end{array}$ & $\begin{array}{l}\text { ORP } \\
(\mathrm{mV})\end{array}$ & $\begin{array}{c}\text { Filtered } \\
\text { chloride } \\
\text { (mg/L) }\end{array}$ \\
\hline \multicolumn{11}{|c|}{ Northern plantation-Continued } \\
\hline \multirow[t]{8}{*}{ P1-1 } & 06-09-99 & $\mathrm{Fe}$ & $<0.01$ & - & - & 930 & 6.4 & 1,350 & - & - \\
\hline & 06-11-02 & $\mathrm{S}$ & $<.01$ & 29 & 400 & 650 & 6.3 & 987 & -80 & 9.3 \\
\hline & $06-22-05$ & $\mathrm{Fe} / \mathrm{S}$ & $<.01$ & 10 & 370 & - & 6.3 & 847 & -72 & 7.1 \\
\hline & $06-12-06$ & $\mathrm{Fe} / \mathrm{S}$ & .01 & 7.8 & 225 & - & 6.2 & 979 & -108 & 7.2 \\
\hline & $06-19-07$ & $\mathrm{~S} / \mathrm{M}$ & .02 & 8.1 & 160 & - & 6.1 & 920 & -139 & 5.7 \\
\hline & $06-16-08$ & $\mathrm{~S} / \mathrm{M}$ & .02 & 12 & 350 & - & 6.5 & 914 & -76 & 4.4 \\
\hline & $06-15-09$ & $\mathrm{~S} / \mathrm{M}$ & .02 & 24 & 325 & - & 6.3 & 830 & -99 & 3.7 \\
\hline & $06-14-10$ & $\mathrm{~S} / \mathrm{M}$ & .02 & 27 & 180 & - & 6.4 & 798 & -117 & 3.4 \\
\hline \multirow{6}{*}{ P1-3 } & $06-22-05$ & $\mathrm{Fe}$ & .03 & 8.4 & 320 & - & 6.4 & 1,200 & -88 & 68 \\
\hline & $06-12-06$ & $\mathrm{Fe}$ & .03 & 7.1 & 330 & & 6 & 1,440 & -152 & 51 \\
\hline & $06-19-07$ & $\mathrm{Fe} / \mathrm{S}$ & .03 & 7.1 & 260 & - & 6.5 & 1,420 & -136 & 55 \\
\hline & $06-17-08$ & $\mathrm{~S} / \mathrm{M}$ & .03 & 14 & 200 & - & 6.4 & 1,230 & & 31 \\
\hline & 06-15-09 & $\mathrm{S} / \mathrm{M}$ & .03 & 18 & 180 & - & 6.2 & 1,220 & -160 & 45 \\
\hline & $06-14-10$ & $\mathrm{~S} / \mathrm{M}$ & .03 & 22 & 350 & - & 6.5 & 1,050 & - & 30 \\
\hline \multirow[t]{7}{*}{ P1-4 } & 06-09-99 & $\mathrm{Fe}$ & 0.02 & - & - & 450 & 6.9 & 867 & - & - \\
\hline & 06-13-01 & $\mathrm{Fe}$ & $<.01$ & 0.93 & - & 390 & 6.6 & 761 & -78 & 53 \\
\hline & $06-11-02$ & $\mathrm{Fe}$ & $<.01$ & 5.9 & 90 & 380 & 6.7 & 734 & -86 & 56 \\
\hline & $06-18-03$ & $\mathrm{Fe}$ & .01 & 4.2 & 70 & - & 6.6 & 778 & 65 & 59 \\
\hline & $06-17-04$ & $\mathrm{Fe}$ & .02 & 1.8 & 60 & - & 6.4 & 782 & -163 & 48 \\
\hline & $06-21-05$ & $\mathrm{Fe}$ & $<.01$ & 1.8 & 42 & - & 6.6 & 750 & -83 & 47 \\
\hline & $06-12-06$ & $\mathrm{Fe}$ & $<.01$ & 1.7 & 32 & - & 6.4 & 823 & -94 & 44 \\
\hline \multirow{5}{*}{ P1-5 } & $06-12-06$ & $\mathrm{Fe} / \mathrm{S}$ & .05 & 6.8 & 370 & - & 5.8 & 1,100 & -106 & 9.9 \\
\hline & $06-19-07$ & $\mathrm{~S} / \mathrm{M}$ & .04 & 8.5 & 350 & - & 6.3 & 1,030 & -104 & 9.3 \\
\hline & $06-16-08$ & $\mathrm{~S} / \mathrm{M}$ & .04 & 14 & 275 & - & 6.3 & 1,080 & 29 & 10 \\
\hline & $06-15-09$ & $\mathrm{~S}$ & .12 & 22 & 500 & - & 6.3 & 1,050 & -165 & 13 \\
\hline & $06-14-10$ & M & .02 & 24 & 400 & - & 6.3 & 990 & - & 9.6 \\
\hline
\end{tabular}


Table 2. Predominant redox conditions at wells and piezometers, and groundwater geochemical data collected at Operable Unit 1, Naval Undersea Warfare Center, Division Keyport, Washington, 1996-2010.-Continued

[All other data were published in Dinicola and others (2002), Dinicola (2003, 2004, 2006), Dinicola and Huffman (2004, 2006, 2007, 2009), and Dinicola and Huffman (2011); prior to 2000, bicarbonate was calculated from an unfiltered sample. Reported concentrations less than the detection limit usually are estimated A range of dissolved hydrogen concentrations are shown when equilibration at a single value was never achieved. Predominant redox conditions: A, aerobic; An, anaerobic, but specific redox condition could not be determined; Fe, iron reducing; M, methanogenic; Mn, manganese reducing; N, nitrate reducing; S, sulfate reducing. Abbreviations: nM, nanomolar; $\mathrm{mg} / \mathrm{L}$, milligram per liter; $\mu \mathrm{S} / \mathrm{cm}$, microsiemens per centimeter at 25 degrees Celsius; ORP, oxidationreduction potential; mV, millivolt. Symbols: E, estimated value; R, data rejected (selected 1996 dissolved-oxygen data were rejected because of inadequate well purging; selected 2002 dissolved-hydrogen data were rejected because of interference from downhole instruments); <, actual value is less than value shown; >, actual value is greater than value shown; -, not analyzed]

\begin{tabular}{|c|c|c|c|c|c|c|c|c|c|c|}
\hline $\begin{array}{c}\text { Well or } \\
\text { piezometer } \\
\text { No. }\end{array}$ & $\begin{array}{c}\text { Date } \\
\text { sampled }\end{array}$ & $\begin{array}{l}\text { Predominant } \\
\text { redox } \\
\text { condition }\end{array}$ & $\begin{array}{l}\text { Dissolved } \\
\text { hydrogen } \\
\text { (nM) }\end{array}$ & $\begin{array}{c}\text { Dissolved } \\
\text { oxygen } \\
\text { (mg/L) }\end{array}$ & $\begin{array}{c}\text { Unfiltered (total) } \\
\text { organic carbon } \\
\text { (mg/L) }\end{array}$ & $\begin{array}{c}\text { Filtered } \\
\text { (dissolved) } \\
\text { organic carbon } \\
\text { (mg/L) }\end{array}$ & $\begin{array}{c}\text { Filtered } \\
\text { nitrate + nitrite } \\
(\mathrm{mg} / \mathrm{L} \text { as } \mathrm{N})\end{array}$ & $\begin{array}{c}\text { Filtered } \\
\text { manganese } \\
(\mathrm{mg} / \mathrm{L})\end{array}$ & $\begin{array}{c}\text { Filtered } \\
\text { iron (II) } \\
\text { (mg/L) }\end{array}$ & $\begin{array}{l}\text { Filtered } \\
\text { sulfate } \\
\text { (mg/L) }\end{array}$ \\
\hline \multicolumn{11}{|c|}{ Southern plantation } \\
\hline \multirow[t]{9}{*}{ MW1-4 } & $09-17-96$ & $\mathrm{Fe}$ & 0.5 & $2.8 \mathrm{R}$ & 2.0 & - & $<0.02$ & 0.28 & 1.8 & 7.1 \\
\hline & $04-16-97$ & $\mathrm{Fe}$ & .6 & .4 & - & - & .24 & - & $<.01$ & 8.6 \\
\hline & $06-07-99$ & $\mathrm{Fe}$ & .9 & .1 & - & - & - & .20 & 1.2 & - \\
\hline & $06-22-00$ & $\mathrm{Fe}$ & .2 & .1 & 8.6 & - & - & .70 & - & 5.5 \\
\hline & 06-14-01 & $\mathrm{S}$ & $0.9-3.2$ & .5 & 2.9 & 2.5 & .08 & .54 & 1.6 & 5.4 \\
\hline & $06-13-02$ & $\mathrm{~S}$ & 2.4 & .1 & - & 3.8 & .08 & .47 & 1.2 & 5.5 \\
\hline & $06-20-03$ & $\mathrm{Fe}$ & .8 & .1 & - & 2.5 & $<.06$ & .53 & .22 & 5.7 \\
\hline & $06-18-04$ & $\mathrm{Fe}$ & .2 & .1 & - & 2.7 & - & .61 & .12 & 5.9 \\
\hline & $06-15-10$ & $\mathrm{Mn} / \mathrm{Fe}$ & $<.1$ & .8 & - & 4.5 & $<.04$ & 1.1 & .3 & 6.4 \\
\hline \multirow[t]{11}{*}{ MW1-5 } & $09-17-96$ & $\mathrm{~S}$ & 1.2 & $<0.1$ & 15 & - & $<0.02$ & 1.6 & 19 & 6.4 \\
\hline & $04-16-97$ & $\mathrm{Fe}$ & .5 & $<.1$ & - & - & .08 & - & 3.1 & 2.8 \\
\hline & 03-04-98 & $\mathrm{Fe}$ & .7 & $<.1$ & 12 & - & - & 1.3 & 4.5 & - \\
\hline & $10-08-98$ & $\mathrm{~S}$ & 2.4 & $<.1$ & - & - & - & 1.5 & 11 & - \\
\hline & 06-08-99 & $\mathrm{Fe}$ & .6 & .3 & - & - & - & 1.2 & 31 & - \\
\hline & $06-22-00$ & $\mathrm{Fe}$ & - & $<.1$ & 17 & - & - & 1.5 & 39 & 6.4 \\
\hline & 06-13-01 & $\mathrm{Fe}$ & .8 & .3 & 10 & 9.6 & .12 & 1.5 & 25 & 6.0 \\
\hline & $06-13-02$ & $\mathrm{~S}$ & 3.4 & .5 & - & 11 & .14 & 1.5 & 20 & 6.3 \\
\hline & $06-20-03$ & $\mathrm{Fe}$ & .1 & .1 & - & 11 & $<.06$ & 1.5 & 30 & 6.8 \\
\hline & $06-18-04$ & $\mathrm{Fe}$ & .1 & .4 & - & 7.2 & - & 1.8 & $>10$ & 5.6 \\
\hline & $06-22-05$ & $\mathrm{Fe}$ & $<.1$ & $<.1$ & - & 8.2 & .16 & 1.2 & 27 & 6.7 \\
\hline \multirow{12}{*}{ MW1-16 } & $06-07-99$ & M & 6.8 & .6 & - & - & - & $>5$ & 140 & - \\
\hline & $06-22-00$ & $\mathrm{~S}$ & - & .1 & 61 & - & - & 1.9 & 60 & 1.2 \\
\hline & $06-14-01$ & $\mathrm{~S}$ & 1.7 & .2 & 64 & 66 & .33 & 2.4 & 56 & 1.1 \\
\hline & $06-13-02$ & M & $4.6-7.6$ & .9 & - & 71 & $<.05$ & 3.2 & 38 & .4 \\
\hline & $06-20-03$ & $\mathrm{~S}$ & 2.2 & .2 & - & 29 & $<.6$ & 2.1 & 37 & .6 \\
\hline & $06-22-04$ & - & - & .1 & - & 36 & - & 2.1 & $>10$ & .1 \\
\hline & $06-23-05$ & $\mathrm{Fe} / \mathrm{S}$ & .5 & .1 & - & 20 & $<.06$ & 2.0 & 66 & .4 \\
\hline & $06-13-06$ & - & - & .1 & - & 17 & $<.06$ & 1.7 & 14 & 20 \\
\hline & $06-20-07$ & $\mathrm{~S}$ & - & $<.1$ & - & 18 & $<.06$ & 1.8 & 44 & 9.7 \\
\hline & $06-18-08$ & $\mathrm{~S}$ & .1 & .1 & - & 17 & $<.04$ & 2.2 & 28 & 10 \\
\hline & 06-16-09 & $\mathrm{Fe} / \mathrm{S}$ & - & .2 & - & B & $<.04$ & 2.6 & 43.7 & 88 \\
\hline & $06-15-10$ & $\mathrm{~S}$ & $<.1$ & .5 & - & 14 & $<.04$ & 1.7 & 22 & 8.6 \\
\hline
\end{tabular}


Table 2. Predominant redox conditions at wells and piezometers, and groundwater geochemical data collected at Operable Unit 1, Naval Undersea Warfare Center, Division Keyport, Washington, 1996-2010.-Continued

[All other data were published in Dinicola and others (2002), Dinicola (2003, 2004, 2006), Dinicola and Huffman (2004, 2006, 2007, 2009), and Dinicola and Huffman (2011); prior to 2000, bicarbonate was calculated from an unfiltered sample. Reported concentrations less than the detection limit usually are estimated. A range of dissolved hydrogen concentrations are shown when equilibration at a single value was never achieved. Predominant redox conditions: A, aerobic; An, anaerobic, but specific redox condition could not be determined; Fe, iron reducing; M, methanogenic; Mn, manganese reducing; N, nitrate reducing; S, sulfate reducing. Abbreviations: nM, nanomolar; mg/L, milligram per liter; $\mu \mathrm{S} / \mathrm{cm}$, microsiemens per centimeter at 25 degrees Celsius; ORP, oxidationreduction potential; mV, millivolt. Symbols: E, estimated value; R, data rejected (selected 1996 dissolved-oxygen data were rejected because of inadequate well purging; selected 2002 dissolved-hydrogen data were rejected because of interference from downhole instruments); $<$, actual value is less than value shown; >, actual value is greater than value shown; -, not analyzed]

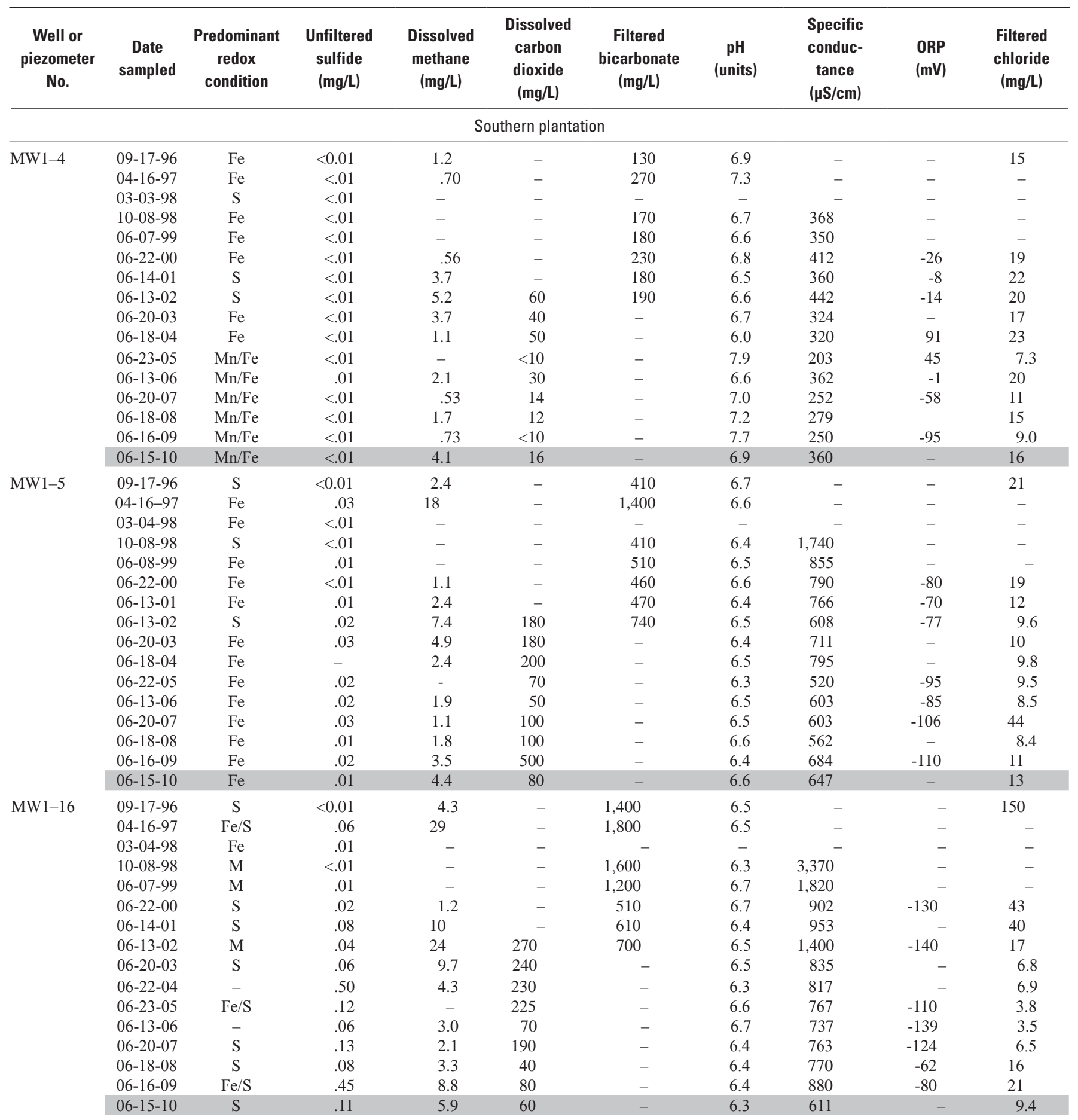


Table 2. Predominant redox conditions at wells and piezometers, and groundwater geochemical data collected at Operable Unit 1, Naval Undersea Warfare Center, Division Keyport, Washington, 1996-2010.-Continued

[All other data were published in Dinicola and others (2002), Dinicola (2003, 2004, 2006), Dinicola and Huffman (2004, 2006, 2007, 2009), and Dinicola and Huffman (2011); prior to 2000, bicarbonate was calculated from an unfiltered sample. Reported concentrations less than the detection limit usually are estimated. A range of dissolved hydrogen concentrations are shown when equilibration at a single value was never achieved. Predominant redox conditions: A, aerobic; An, anaerobic, but specific redox condition could not be determined; Fe, iron reducing; M, methanogenic; Mn, manganese reducing; N, nitrate reducing; S, sulfate reducing. Abbreviations: nM, nanomolar; mg/L, milligram per liter; $\mu \mathrm{S} / \mathrm{cm}$, microsiemens per centimeter at 25 degrees Celsius; ORP, oxidationreduction potential; mV, millivolt. Symbols: E, estimated value; R, data rejected (selected 1996 dissolved-oxygen data were rejected because of inadequate well purging; selected 2002 dissolved-hydrogen data were rejected because of interference from downhole instruments); <, actual value is less than value shown; >, actual value is greater than value shown; -, not analyzed]

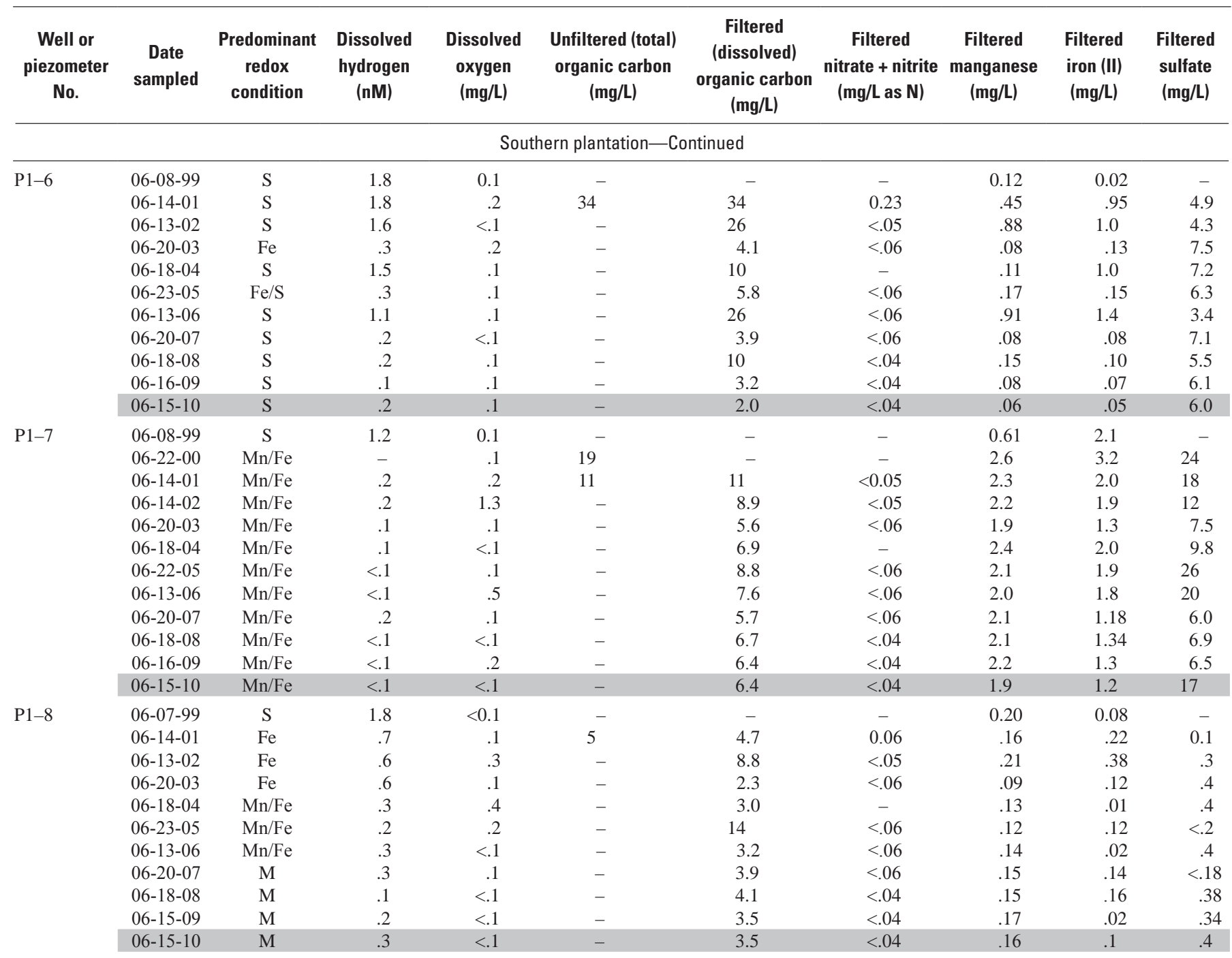


Table 2. Predominant redox conditions at wells and piezometers, and groundwater geochemical data collected at Operable Unit 1, Naval Undersea Warfare Center, Division Keyport, Washington, 1996-2010.-Continued

[All other data were published in Dinicola and others (2002), Dinicola (2003, 2004, 2006), Dinicola and Huffman (2004, 2006, 2007, 2009), and Dinicola and Huffman (2011); prior to 2000, bicarbonate was calculated from an unfiltered sample. Reported concentrations less than the detection limit usually are estimated. A range of dissolved hydrogen concentrations are shown when equilibration at a single value was never achieved. Predominant redox conditions: A, aerobic; An, anaerobic, but specific redox condition could not be determined; Fe, iron reducing; M, methanogenic; Mn, manganese reducing; N, nitrate reducing; S, sulfate reducing. Abbreviations: nM, nanomolar; $\mathrm{mg} / \mathrm{L}$, milligram per liter; $\mu \mathrm{S} / \mathrm{cm}$, microsiemens per centimeter at 25 degrees Celsius; ORP, oxidationreduction potential; mV, millivolt. Symbols: E, estimated value; R, data rejected (selected 1996 dissolved-oxygen data were rejected because of inadequate well purging; selected 2002 dissolved-hydrogen data were rejected because of interference from downhole instruments); $<$, actual value is less than value shown; >, actual value is greater than value shown; -, not analyzed]

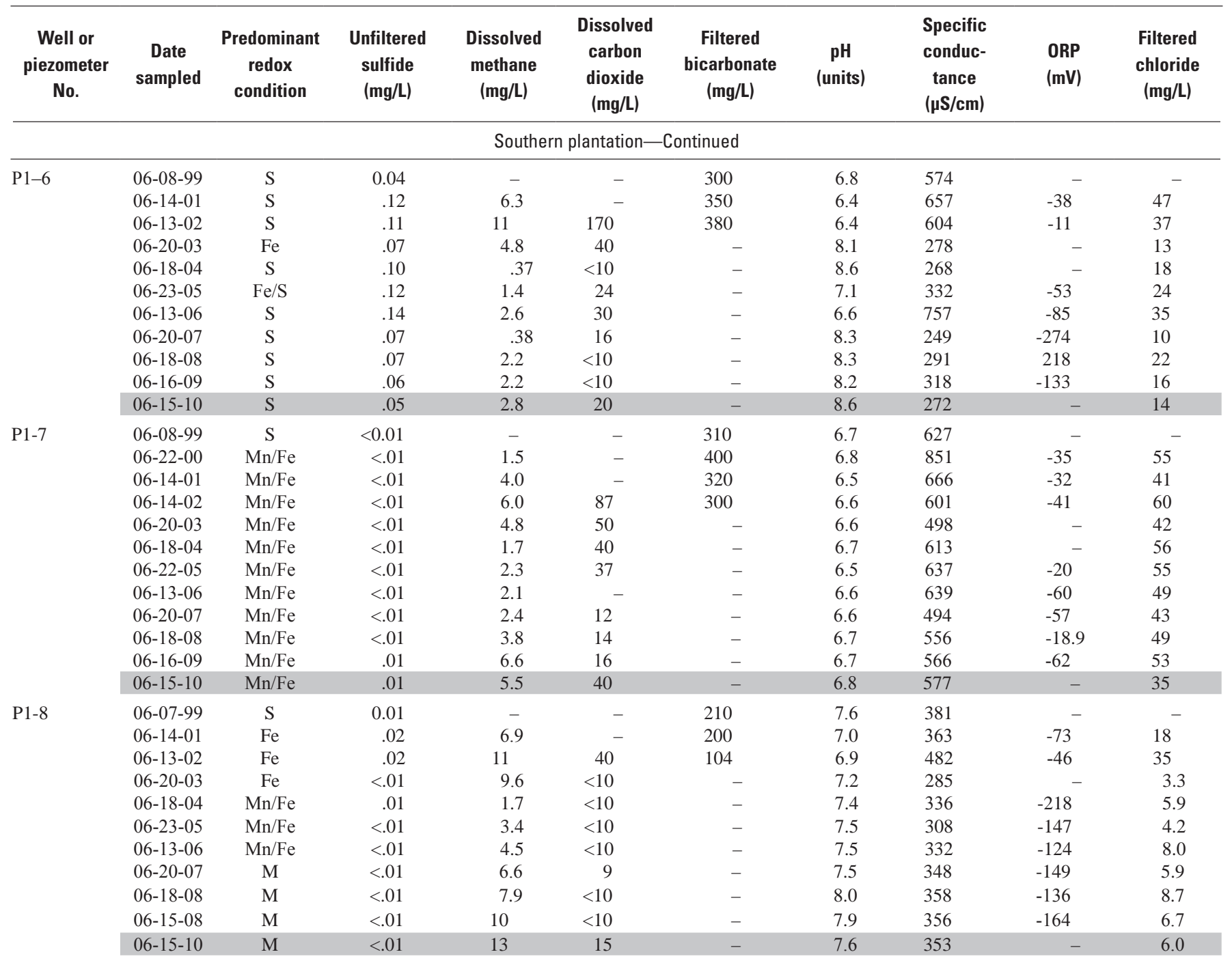


Table 2. Predominant redox conditions at wells and piezometers, and groundwater geochemical data collected at Operable Unit 1, Naval Undersea Warfare Center, Division Keyport, Washington, 1996-2010.-Continued

[All other data were published in Dinicola and others (2002), Dinicola (2003, 2004, 2006), Dinicola and Huffman (2004, 2006, 2007, 2009), and Dinicola and Huffman (2011); prior to 2000, bicarbonate was calculated from an unfiltered sample. Reported concentrations less than the detection limit usually are estimated. A range of dissolved hydrogen concentrations are shown when equilibration at a single value was never achieved. Predominant redox conditions: A, aerobic; An, anaerobic, but specific redox condition could not be determined; Fe, iron reducing; M, methanogenic; Mn, manganese reducing; N, nitrate reducing; S, sulfate reducing. Abbreviations: nM, nanomolar; mg/L, milligram per liter; $\mu \mathrm{S} / \mathrm{cm}$, microsiemens per centimeter at 25 degrees Celsius; ORP, oxidationreduction potential; mV, millivolt. Symbols: E, estimated value; R, data rejected (selected 1996 dissolved-oxygen data were rejected because of inadequate well purging; selected 2002 dissolved-hydrogen data were rejected because of interference from downhole instruments); <, actual value is less than value shown; >, actual value is greater than value shown; -, not analyzed]

\begin{tabular}{|c|c|c|c|c|c|c|c|c|c|c|}
\hline $\begin{array}{c}\text { Well or } \\
\text { piezometer } \\
\text { No. }\end{array}$ & $\begin{array}{c}\text { Date } \\
\text { sampled }\end{array}$ & $\begin{array}{c}\text { Predominant } \\
\text { redox } \\
\text { condition }\end{array}$ & $\begin{array}{l}\text { Dissolved } \\
\text { hydrogen } \\
\text { (nM) }\end{array}$ & $\begin{array}{c}\text { Dissolved } \\
\text { oxygen } \\
\text { (mg/L) }\end{array}$ & $\begin{array}{l}\text { Unfiltered (total) } \\
\text { organic carbon } \\
\text { (mg/L) }\end{array}$ & $\begin{array}{c}\text { Filtered } \\
\text { (dissolved) } \\
\text { organic carbon } \\
\text { (mg/L) }\end{array}$ & $\begin{array}{c}\text { Filtered } \\
\text { nitrate + nitrite } \\
(\mathrm{mg} / \mathrm{L} \text { as } \mathrm{N})\end{array}$ & $\begin{array}{c}\text { Filtered } \\
\text { manganese } \\
\text { (mg/L) }\end{array}$ & $\begin{array}{c}\text { Filtered } \\
\text { iron (II) } \\
\text { (mg/L) }\end{array}$ & $\begin{array}{l}\text { Filtered } \\
\text { sulfate } \\
\text { (mg/L) }\end{array}$ \\
\hline \multicolumn{11}{|c|}{ Southern plantation-Continued } \\
\hline \multirow[t]{8}{*}{ P1-9 } & 06-08-99 & M & 19 & 0.3 & - & - & - & 0.90 & 0.03 & - \\
\hline & $06-22-00$ & $\mathrm{~S} / \mathrm{M}$ & - & .1 & 10 & - & - & .69 & .20 & 6.6 \\
\hline & $06-20-03$ & $\mathrm{Fe}$ & .2 & .1 & - & 3.7 & $<.06$ & .24 & $<.01$ & 7.0 \\
\hline & 06-18-04 & $\mathrm{Mn} / \mathrm{Fe}$ & .2 & .1 & - & 4.0 & - & .26 & .14 & 7.3 \\
\hline & $06-23-05$ & $\mathrm{Mn}$ & $<.1$ & .1 & - & 1.4 & $<.06$ & .11 & .01 & 8.7 \\
\hline & $06-13-06$ & S & 4.4 & .2 & - & 9.6 & $<.06$ & 1.4 & .33 & 5.3 \\
\hline & $06-20-07$ & $\mathrm{Mn} / \mathrm{Fe}$ & .2 & .1 & - & 4.5 & $<.06$ & .28 & .13 & 7.04 \\
\hline & $06-18-08$ & $\mathrm{Mn} / \mathrm{Fe}$ & E.2.5 & $<.1$ & - & 10 & $<.04$ & .17 & .07 & 7.89 \\
\hline \multirow{9}{*}{ P1-10 } & $06-12-02$ & $\mathrm{Fe}$ & .3 & .1 & - & 3.5 & $<.05$ & .05 & .41 & $<.1$ \\
\hline & $06-19-03$ & $\mathrm{Fe}$ & .2 & .1 & - & 3.5 & $<.06$ & .42 & .34 & 2.6 \\
\hline & $06-18-04$ & $\mathrm{Mn} / \mathrm{Fe}$ & .1 & .1 & - & 3.5 & - & .58 & .35 & $<.2$ \\
\hline & $06-22-05$ & $\mathrm{Mn} / \mathrm{Fe}$ & .1 & .1 & - & 3.3 & $<.06$ & .74 & .24 & $<.2$ \\
\hline & $06-13-06$ & $\mathrm{Mn} / \mathrm{Fe}$ & $<.1$ & .1 & - & 3.4 & $<.06$ & .92 & .15 & $<.2$ \\
\hline & $06-20-07$ & M & E.1 & $<.1$ & - & 4.2 & $<.06$ & .10 & .31 & $<.18$ \\
\hline & $06-18-08$ & $\mathrm{M}$ & $<.1$ & $<.1$ & - & 4.2 & $<.04$ & .12 & .23 & $<.18$ \\
\hline & 06-15-09 & M & .1 & .1 & - & 4.0 & $<.04$ & .24 & .28 & $<.2$ \\
\hline & $06-14-10$ & $\mathrm{M}$ & .2 & .1 & - & 5 & $<.04$ & .28 & .19 & $<.2$ \\
\hline \multicolumn{11}{|c|}{ Intermediate aquifer } \\
\hline \multirow[t]{7}{*}{ MW1-25 } & $09-17-96$ & $\mathrm{Fe}$ & 0.4 & $2.7 \mathrm{R}$ & 7.4 & - & 0.14 & 0.16 & 0.74 & 16 \\
\hline & $04-17-97$ & $\mathrm{Fe}$ & .8 & .1 & - & - & $<.02$ & - & .88 & 15 \\
\hline & 06-14-06 & $\mathrm{Fe}$ & .1 & .1 & - & 6.3 & $<.06$ & .14 & .97 & 8.1 \\
\hline & $06-18-07$ & $\mathrm{Fe}$ & .2 & $<.1$ & - & 6.6 & $<.06$ & .14 & .87 & 7.1 \\
\hline & $06-17-08$ & $\mathrm{Fe}$ & $<.1$ & .1 & - & 6.4 & $<.04$ & .13 & .86 & 6.9 \\
\hline & 06-17-09 & $\mathrm{Fe}$ & .2 & .1 & - & 6.7 & $<.04$ & .15 & 1.1 & 6.9 \\
\hline & $06-15-10$ & $\mathrm{Fe}$ & .3 & .8 & - & 6.6 & .05 & .13 & .78 & 6.6 \\
\hline
\end{tabular}


Table 2. Predominant redox conditions at wells and piezometers, and groundwater geochemical data collected at Operable Unit 1, Naval Undersea Warfare Center, Division Keyport, Washington, 1996-2010.—Continued

[All other data were published in Dinicola and others (2002), Dinicola (2003, 2004, 2006), Dinicola and Huffman (2004, 2006, 2007, 2009), and Dinicola and Huffman (2011); prior to 2000, bicarbonate was calculated from an unfiltered sample. Reported concentrations less than the detection limit usually are estimated. A range of dissolved hydrogen concentrations are shown when equilibration at a single value was never achieved. Predominant redox conditions: A, aerobic; An, anaerobic, but specific redox condition could not be determined; Fe, iron reducing; M, methanogenic; Mn, manganese reducing; N, nitrate reducing; S, sulfate reducing. Abbreviations: nM, nanomolar; $\mathrm{mg} / \mathrm{L}$, milligram per liter; $\mu \mathrm{S} / \mathrm{cm}$, microsiemens per centimeter at 25 degrees Celsius; ORP, oxidationreduction potential; mV, millivolt. Symbols: E, estimated value; R, data rejected (selected 1996 dissolved-oxygen data were rejected because of inadequate well purging; selected 2002 dissolved-hydrogen data were rejected because of interference from downhole instruments); $<$, actual value is less than value shown; >, actual value is greater than value shown; -, not analyzed]

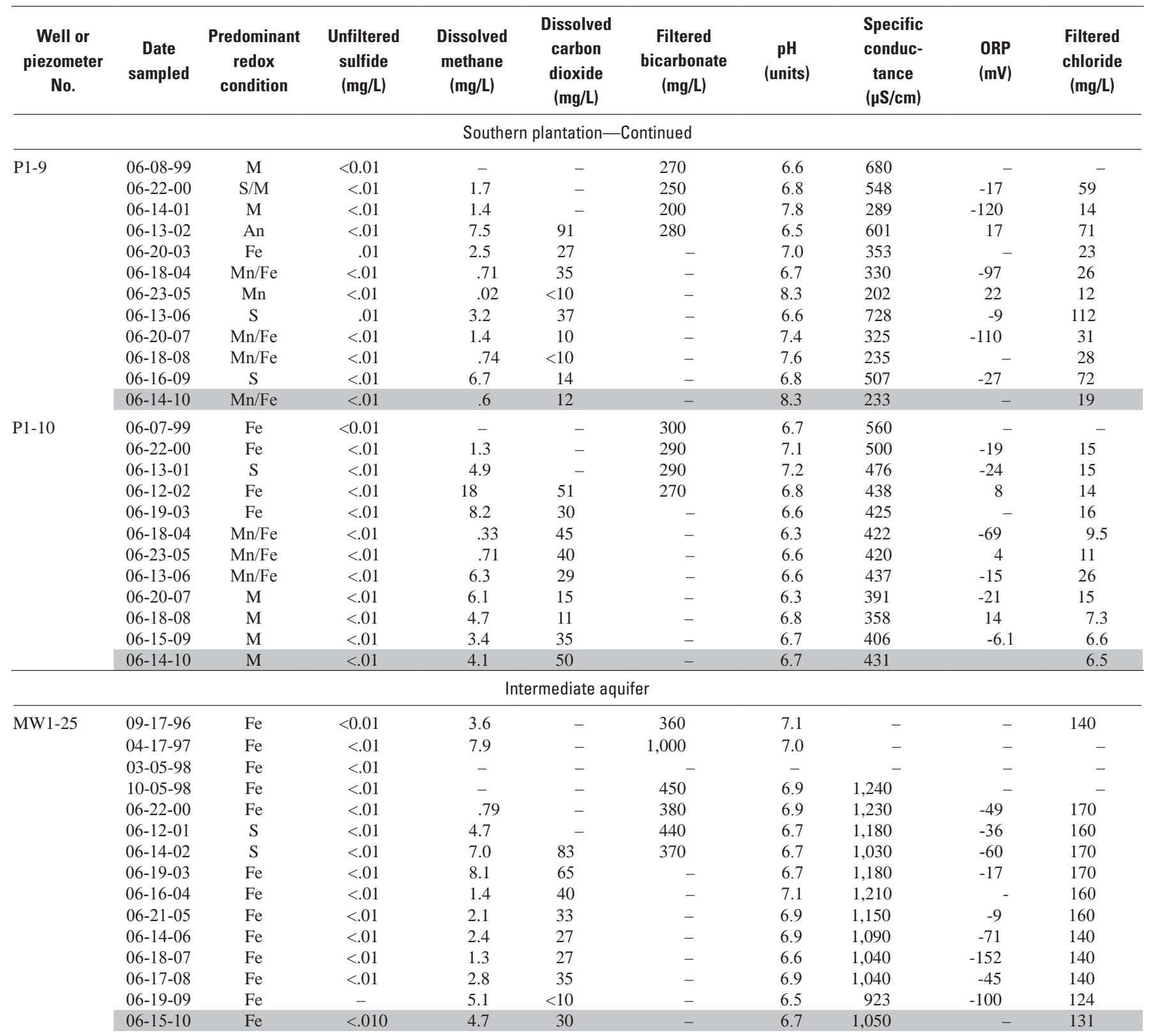


Table 2. Predominant redox conditions at wells and piezometers, and groundwater geochemical data collected at Operable Unit 1, Naval Undersea Warfare Center, Division Keyport, Washington, 1996-2010.-Continued

[All other data were published in Dinicola and others (2002), Dinicola (2003, 2004, 2006), Dinicola and Huffman (2004, 2006, 2007, 2009), and Dinicola and Huffman (2011); prior to 2000, bicarbonate was calculated from an unfiltered sample. Reported concentrations less than the detection limit usually are estimated. A range of dissolved hydrogen concentrations are shown when equilibration at a single value was never achieved. Predominant redox conditions: A, aerobic; An, anaerobic, but specific redox condition could not be determined; Fe, iron reducing; M, methanogenic; Mn, manganese reducing; N, nitrate reducing; S, sulfate reducing. Abbreviations: nM, nanomolar; mg/L, milligram per liter; $\mu \mathrm{S} / \mathrm{cm}$, microsiemens per centimeter at 25 degrees Celsius; ORP, oxidationreduction potential; mV, millivolt. Symbols: E, estimated value; R, data rejected (selected 1996 dissolved-oxygen data were rejected because of inadequate well purging; selected 2002 dissolved-hydrogen data were rejected because of interference from downhole instruments); <, actual value is less than value shown; >, actual value is greater than value shown; -, not analyzed]

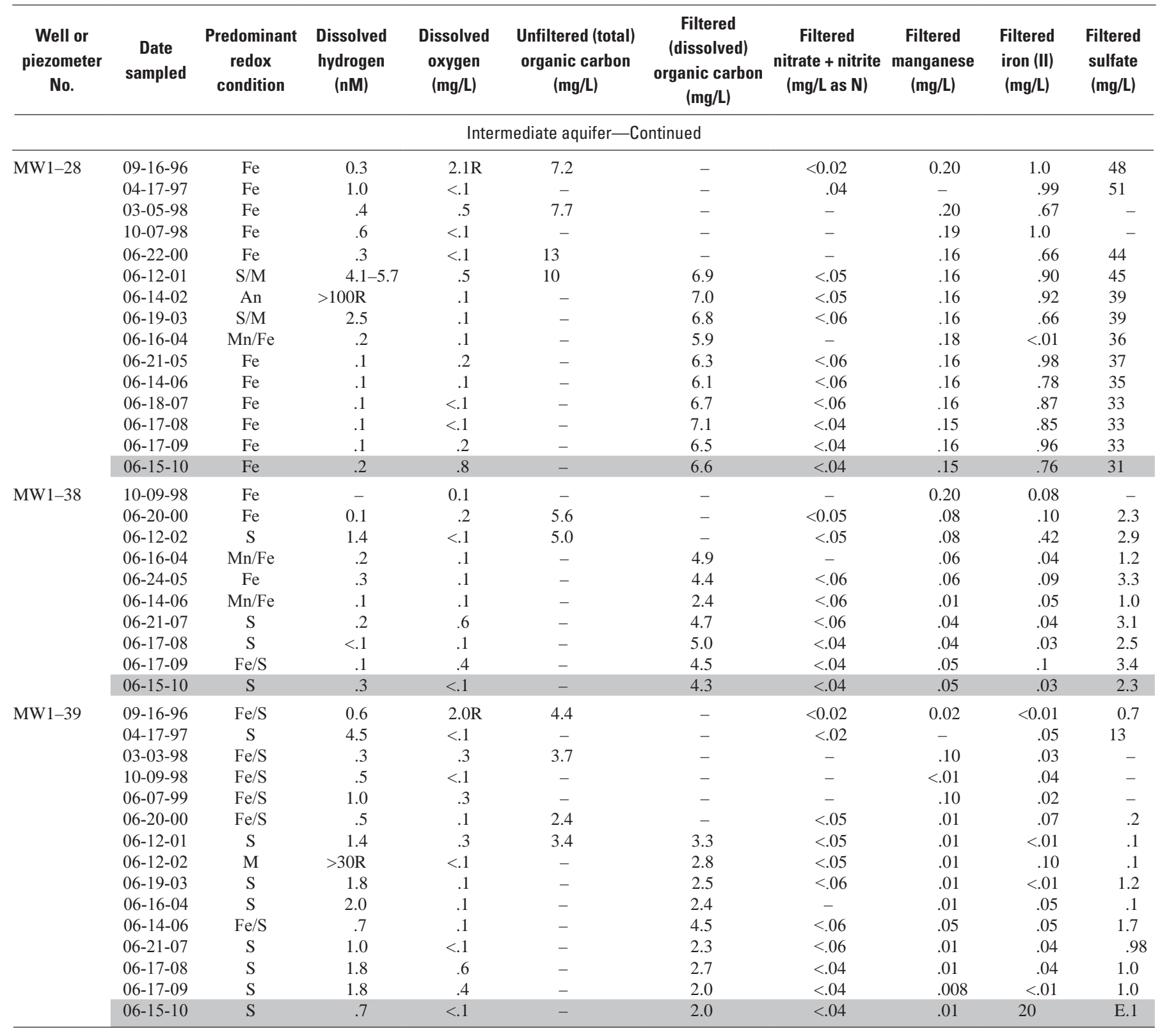


Table 2. Predominant redox conditions at wells and piezometers, and groundwater geochemical data collected at Operable Unit 1, Naval Undersea Warfare Center, Division Keyport, Washington, 1996-2010.-Continued

[All other data were published in Dinicola and others (2002), Dinicola (2003, 2004, 2006), Dinicola and Huffman (2004, 2006, 2007, 2009), and Dinicola and Huffman (2011); prior to 2000, bicarbonate was calculated from an unfiltered sample. Reported concentrations less than the detection limit usually are estimated. A range of dissolved hydrogen concentrations are shown when equilibration at a single value was never achieved. Predominant redox conditions: A, aerobic; An, anaerobic, but specific redox condition could not be determined; Fe, iron reducing; M, methanogenic; Mn, manganese reducing; N, nitrate reducing; S, sulfate reducing. Abbreviations: nM, nanomolar; $\mathrm{mg} / \mathrm{L}$, milligram per liter; $\mu \mathrm{S} / \mathrm{cm}$, microsiemens per centimeter at 25 degrees Celsius; ORP, oxidationreduction potential; mV, millivolt. Symbols: E, estimated value; R, data rejected (selected 1996 dissolved-oxygen data were rejected because of inadequate well purging; selected 2002 dissolved-hydrogen data were rejected because of interference from downhole instruments); $<$, actual value is less than value shown; >, actual value is greater than value shown; -, not analyzed]

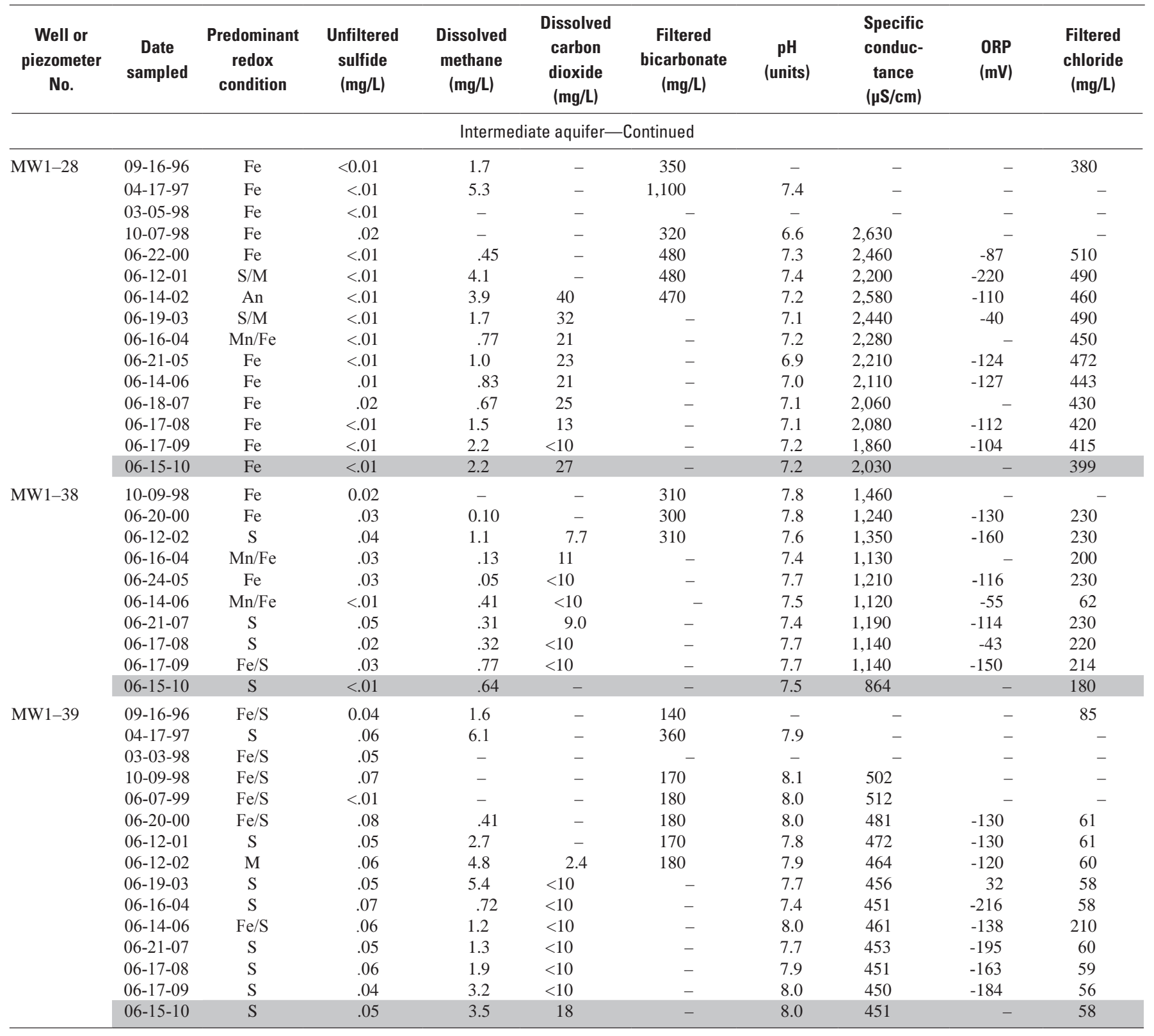


Table 3. Potential relative efficiency of chloroethene biodegradation through reductive dechlorination or microbial oxidation as a function of groundwater reduction-oxidation (redox) conditions.

[From Bradley, 2003. Abbreviations: PCE, tetrachloroethene; TCE, trichloroethene; cis-DCE, cis-1,2-dichloroethene; VC, vinyl chloride; -, indicates no evidence for this mechanism under this redox condition; $\mathrm{RD}$, reductive dechlorination; $\mathrm{MO}$, microbial oxidation]

\begin{tabular}{|c|c|c|c|c|c|c|}
\hline Contaminant & $\begin{array}{c}\text { Biodegradation } \\
\text { mechanism }\end{array}$ & \multicolumn{5}{|c|}{ Predominant redox condition } \\
\hline PCE & MO & Fair $^{1}$ & - & - & - & - \\
\hline TCE & $\mathrm{RD}$ & - & Fair & Good & Good & Excellent \\
\hline cis-DCE & MO & Excellent & Good & Poor & Poor & Poor \\
\hline \multirow[t]{2}{*}{ VC } & $\mathrm{RD}$ & Poor & Poor & Poor & Fair & Fair \\
\hline & MO & Excellent & Excellent & Excellent & Good & Good $^{2}$ \\
\hline
\end{tabular}

\footnotetext{
${ }^{1}$ Aerobic cometabolism only - considered to be a transient mechanism.
}

${ }^{2}$ Associated with humic-acids reduction rather than methanogenic activity. 
Table 3

This page intentionally left blank. 
Table 4. Concentrations of selected volatile organic compounds in water samples collected by the U.S. Geological Survey from selected monitoring wells, piezometers, and passive-diffusion samplers at Operable Unit 1, Naval Undersea Warfare Center, Division Keyport, Washington, 1999-2010.

[All data except those shaded were published previously in Dinicola and others (2002), Dinicola (2003, 2004, 2006), Dinicola and Huffman (2004, 2006, 2007, 2009), and Dinicola and Huffman (2011). Laboratory data qualifier codes, such as "D" for dilution, are not shown. Volatile organic compounds (VOCs); PCE, tetrachloroethene; TCE, trichloroethene; cis-DCE, cis-1,2-dichloroethene; trans-DCE, trans-1,2-dichloroethene; VC, vinyl chloride; 1,1,1-TCA, 1,1,1-trichloroethane; 1,1-DCA, 1,1-dichloroethane; CA, chloroethane; 1,1-DCE, 1,1-dichloroethene; total BTEX, sum of benzene, toluene, ethylbenzene, and xylene; total CVOCs, sum of chlorinated volatile organic compounds. Abbreviations: E, estimated value; M, presence verified but not quantified; $\mu \mathrm{g} / \mathrm{L}$, microgram per liter; dup, duplicate; blank, field blank; <, actual value is less than value shown; ND, not detected; -, not analyzed]

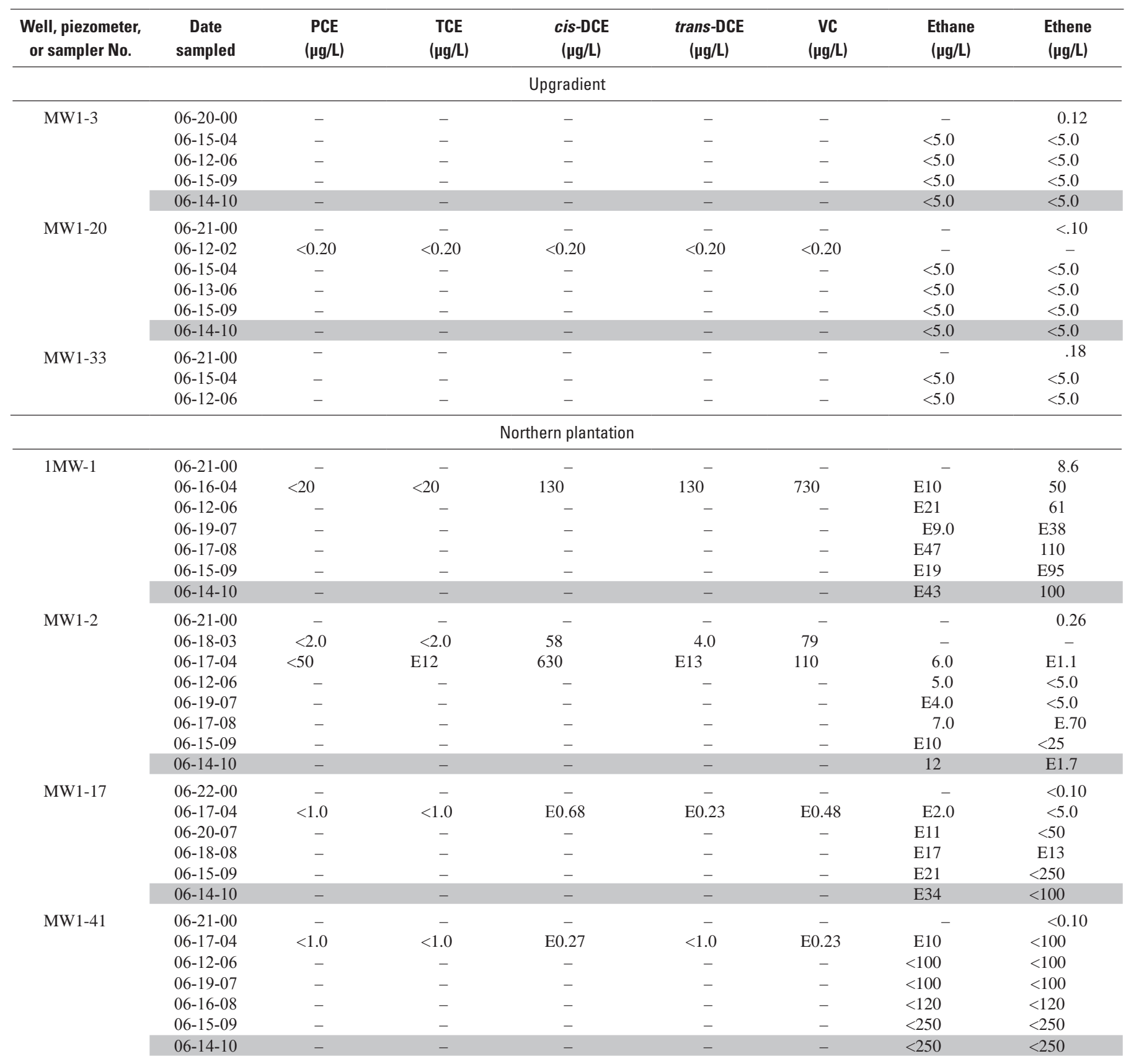


Table 4. Concentrations of selected volatile organic compounds in water samples collected by the U.S. Geological Survey from selected monitoring wells, piezometers, and passive-diffusion samplers at Operable Unit 1, Naval Undersea Warfare Center, Division Keyport, Washington, 1999-2010.-Continued

[All data except those shaded were published previously in Dinicola and others (2002), Dinicola (2003, 2004, 2006), Dinicola and Huffman (2004, 2006, 2007, 2009), and Dinicola and Huffman (2011). Laboratory data qualifier codes, such as "D" for dilution, are not shown. Volatile organic compounds (VOCs); PCE, tetrachloroethene; TCE, trichloroethene; cis-DCE, cis-1,2-dichloroethene; trans-DCE, trans-1,2-dichloroethene; VC, vinyl chloride; 1,1,1-TCA, 1,1,1-trichloroethane; 1,1-DCA, 1,1-dichloroethane; CA, chloroethane; 1,1-DCE, 1,1-dichloroethene; total BTEX, sum of benzene, toluene, ethylbenzene, and xylene; total CVOCs, sum of chlorinated volatile organic compounds. Abbreviations: E, estimated value; M, presence verified but not quantified; $\mu \mathrm{g} / \mathrm{L}$, microgram per liter; dup, duplicate; blank, field blank; <, actual value is less than value shown; ND, not detected; -, not analyzed]

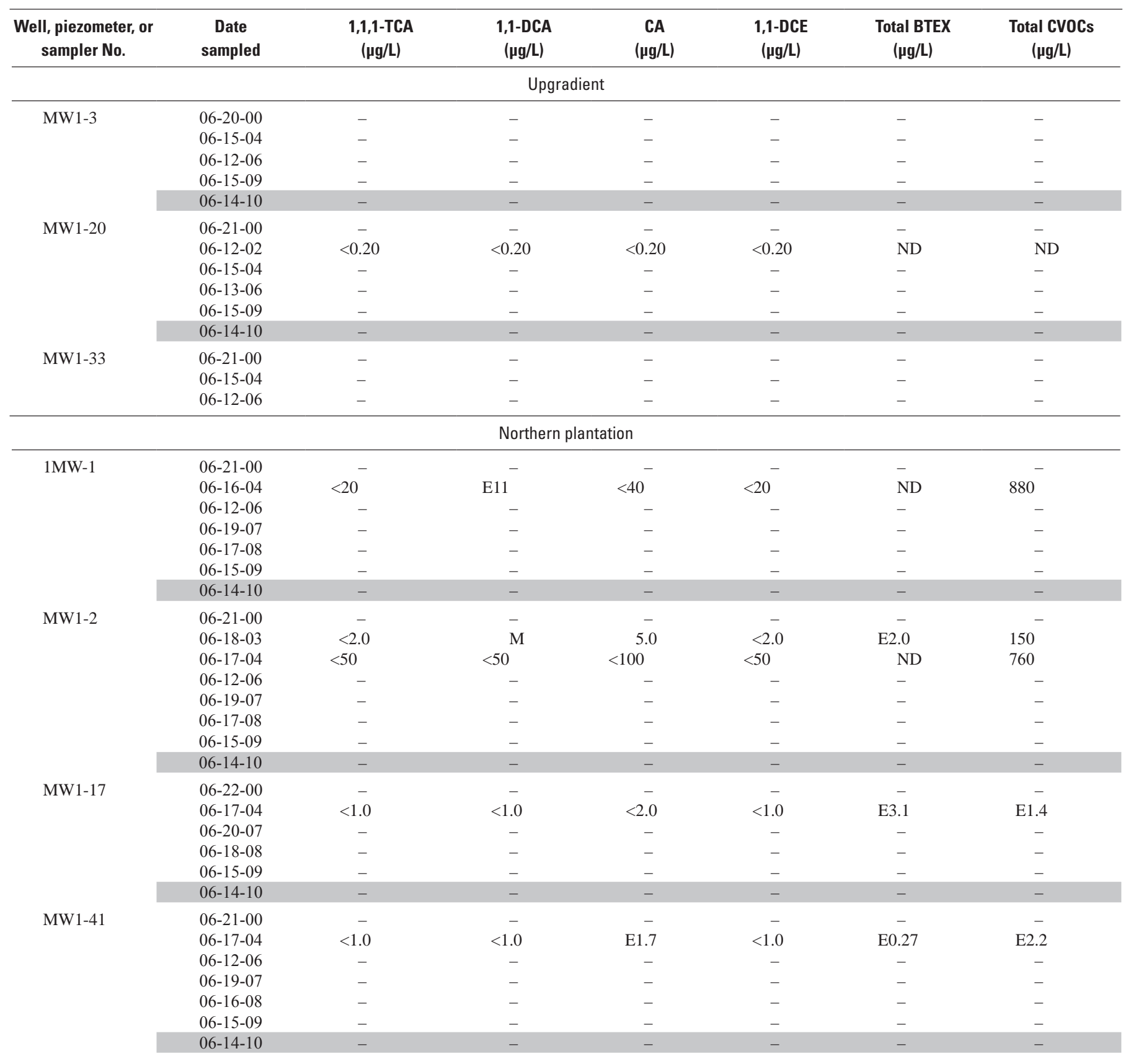


Table 4. Concentrations of selected volatile organic compounds in water samples collected by the U.S. Geological Survey from selected monitoring wells, piezometers, and passive-diffusion samplers at Operable Unit 1, Naval Undersea Warfare Center, Division Keyport, Washington, 1999-2010.-Continued

[All data except those shaded were published previously in Dinicola and others (2002), Dinicola (2003, 2004, 2006), Dinicola and Huffman (2004, 2006, 2007, 2009), and Dinicola and Huffman (2011). Laboratory data qualifier codes, such as "D" for dilution, are not shown. Volatile organic compounds (VOCs); PCE, tetrachloroethene; TCE, trichloroethene; cis-DCE, cis-1,2-dichloroethene; trans-DCE, trans-1,2-dichloroethene; VC, vinyl chloride; 1,1,1-TCA, 1,1,1-trichloroethane; 1,1-DCA, 1,1-dichloroethane; CA, chloroethane; 1,1-DCE, 1,1-dichloroethene; total BTEX, sum of benzene, toluene, ethylbenzene, and xylene; total CVOCs, sum of chlorinated volatile organic compounds. Abbreviations: E, estimated value; M, presence verified but not quantified; $\mu \mathrm{g} / \mathrm{L}$, microgram per liter; dup, duplicate; blank, field blank; <, actual value is less than value shown; ND, not detected; -, not analyzed]

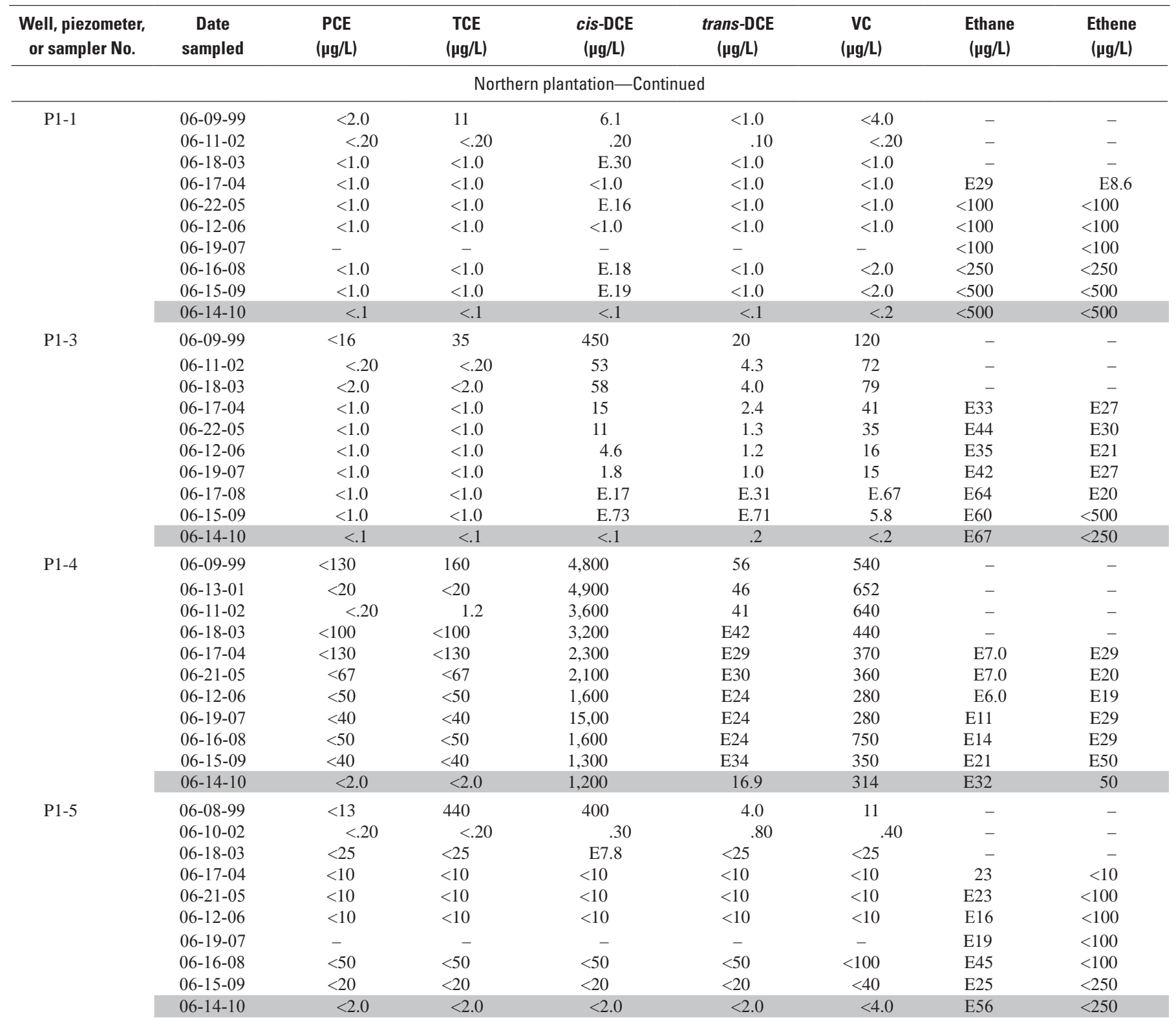


Table 4. Concentrations of selected volatile organic compounds in water samples collected by the U.S. Geological Survey from selected monitoring wells, piezometers, and passive-diffusion samplers at Operable Unit 1, Naval Undersea Warfare Center, Division Keyport, Washington, 1999-2010.-Continued

[All data except those shaded were published previously in Dinicola and others (2002), Dinicola (2003, 2004, 2006), Dinicola and Huffman (2004, 2006, 2007, 2009), and Dinicola and Huffman (2011). Laboratory data qualifier codes, such as "D" for dilution, are not shown. Volatile organic compounds (VOCs); PCE, tetrachloroethene; TCE, trichloroethene; cis-DCE, cis-1,2-dichloroethene; trans-DCE, trans-1,2-dichloroethene; VC, vinyl chloride; 1,1,1-TCA, 1,1,1-trichloroethane; 1,1-DCA, 1,1-dichloroethane; CA, chloroethane; 1,1-DCE, 1,1-dichloroethene; total BTEX, sum of benzene, toluene, ethylbenzene, and xylene; total CVOCs, sum of chlorinated volatile organic compounds. Abbreviations: E, estimated value; M, presence verified but not quantified; $\mu \mathrm{g} / \mathrm{L}$, microgram per liter; dup, duplicate; blank, field blank; <, actual value is less than value shown; ND, not detected; -, not analyzed]

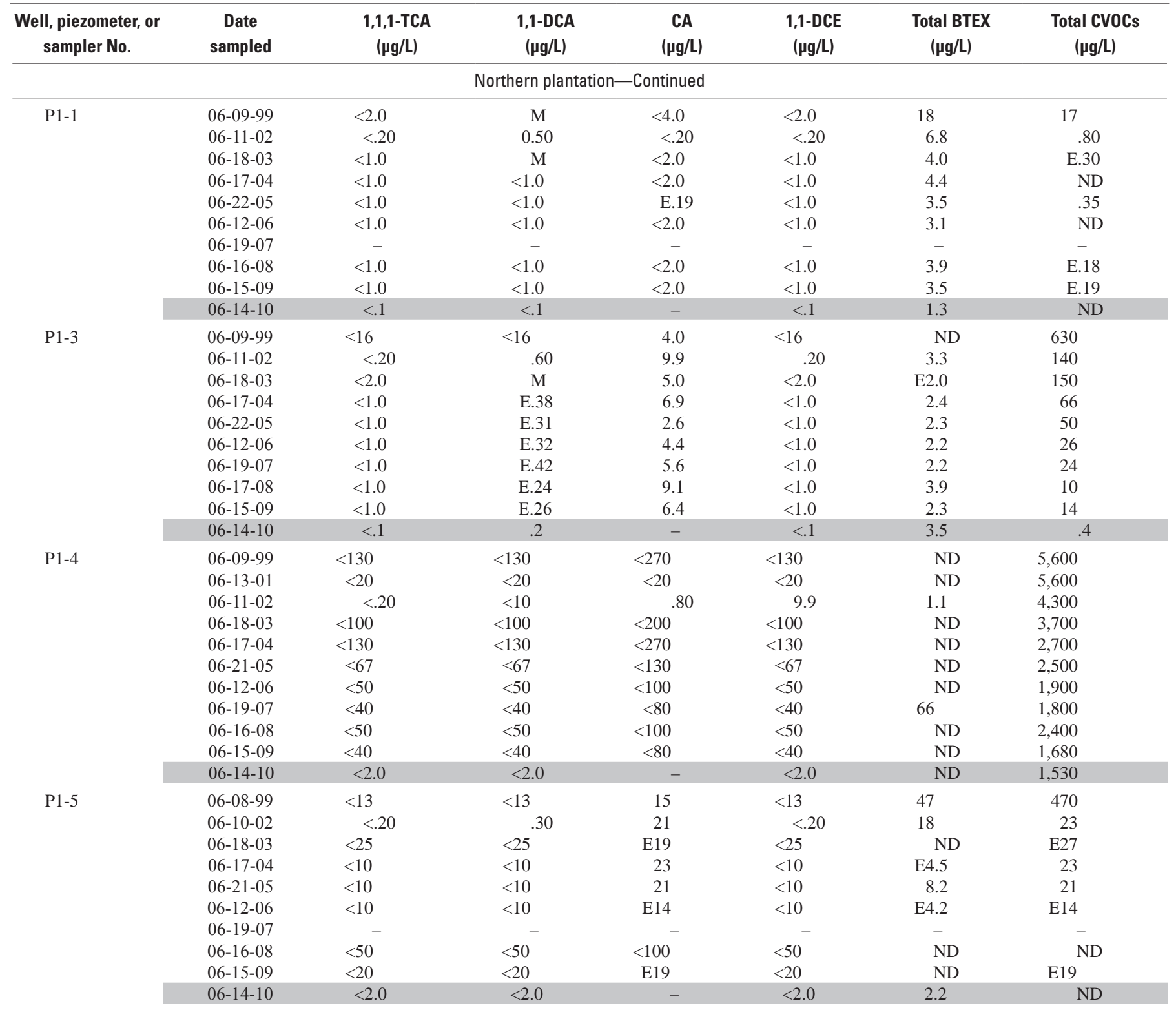


Table 4. Concentrations of selected volatile organic compounds in water samples collected by the U.S. Geological Survey from selected monitoring wells, piezometers, and passive-diffusion samplers at Operable Unit 1, Naval Undersea Warfare Center, Division Keyport, Washington, 1999-2010.-Continued

[All data except those shaded were published previously in Dinicola and others (2002), Dinicola (2003, 2004, 2006), Dinicola and Huffman (2004, 2006, 2007, 2009), and Dinicola and Huffman (2011). Laboratory data qualifier codes, such as "D" for dilution, are not shown. Volatile organic compounds (VOCs); PCE, tetrachloroethene; TCE, trichloroethene; cis-DCE, cis-1,2-dichloroethene; trans-DCE, trans-1,2-dichloroethene; VC, vinyl chloride; 1,1,1-TCA, 1,1,1-trichloroethane; 1,1-DCA, 1,1-dichloroethane; CA, chloroethane; 1,1-DCE, 1,1-dichloroethene; total BTEX, sum of benzene, toluene, ethylbenzene, and xylene; total CVOCs, sum of chlorinated volatile organic compounds. Abbreviations: E, estimated value; M, presence verified but not quantified; $\mu \mathrm{g} / \mathrm{L}$, microgram per liter; dup, duplicate; blank, field blank; $<$, actual value is less than value shown; ND, not detected; -, not analyzed]

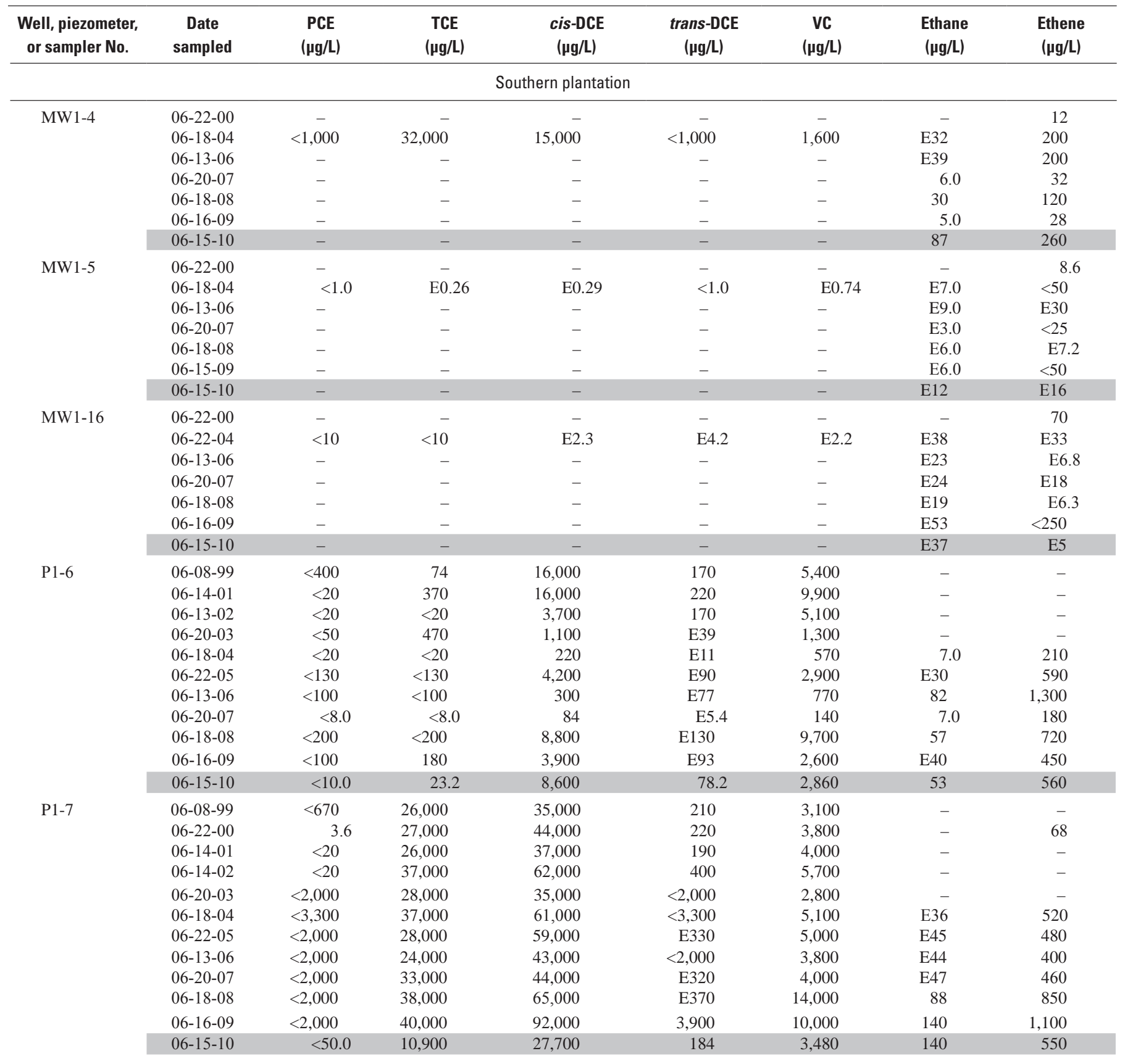


Table 4. Concentrations of selected volatile organic compounds in water samples collected by the U.S. Geological Survey from selected monitoring wells, piezometers, and passive-diffusion samplers at Operable Unit 1, Naval Undersea Warfare Center, Division Keyport, Washington, 1999-2010.-Continued

[All data except those shaded were published previously in Dinicola and others (2002), Dinicola (2003, 2004, 2006), Dinicola and Huffman (2004, 2006, 2007, 2009), and Dinicola and Huffman (2011). Laboratory data qualifier codes, such as "D" for dilution, are not shown. Volatile organic compounds

(VOCs); PCE, tetrachloroethene; TCE, trichloroethene; cis-DCE, cis-1,2-dichloroethene; trans-DCE, trans-1,2-dichloroethene; VC, vinyl chloride; 1,1,1-TCA, 1,1,1-trichloroethane; 1,1-DCA, 1,1-dichloroethane; CA, chloroethane; 1,1-DCE, 1,1-dichloroethene; total BTEX, sum of benzene, toluene, ethylbenzene, and xylene; total CVOCs, sum of chlorinated volatile organic compounds. Abbreviations: E, estimated value; M, presence verified but not quantified; $\mu \mathrm{g} / \mathrm{L}$, microgram per liter; dup, duplicate; blank, field blank; <, actual value is less than value shown; ND, not detected; -, not analyzed]

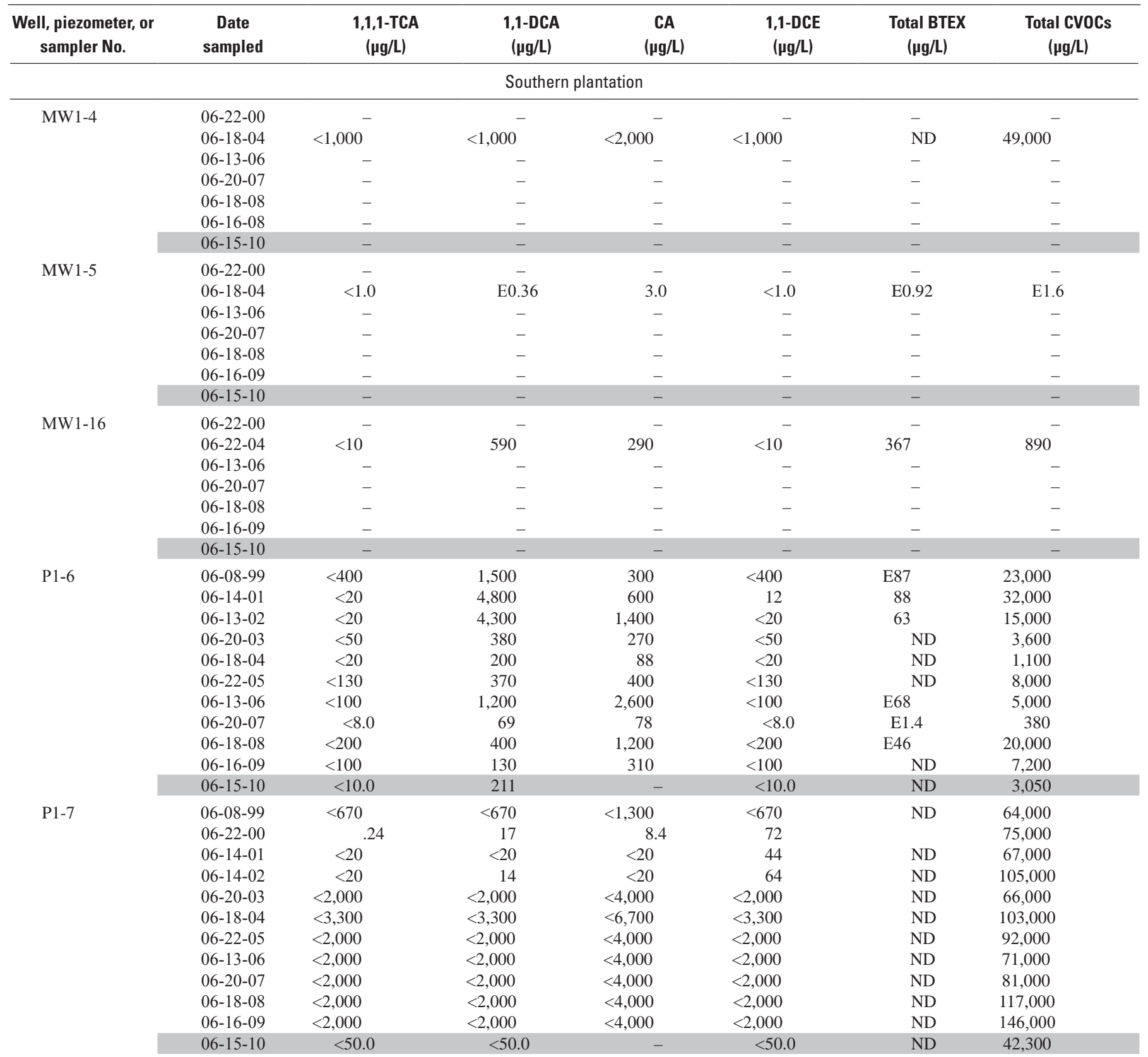


Table 4. Concentrations of selected volatile organic compounds in water samples collected by the U.S. Geological Survey from selected monitoring wells, piezometers, and passive-diffusion samplers at Operable Unit 1, Naval Undersea Warfare Center, Division Keyport, Washington, 1999-2010.-Continued

[All data except those shaded were published previously in Dinicola and others (2002), Dinicola (2003, 2004, 2006), Dinicola and Huffman (2004, 2006, 2007, 2009), and Dinicola and Huffman (2011). Laboratory data qualifier codes, such as "D" for dilution, are not shown. Volatile organic compounds (VOCs); PCE, tetrachloroethene; TCE, trichloroethene; cis-DCE, cis-1,2-dichloroethene; trans-DCE, trans-1,2-dichloroethene; VC, vinyl chloride; 1,1,1-TCA, 1,1,1-trichloroethane; 1,1-DCA, 1,1-dichloroethane; CA, chloroethane; 1,1-DCE, 1,1-dichloroethene; total BTEX, sum of benzene, toluene, ethylbenzene, and xylene; total CVOCs, sum of chlorinated volatile organic compounds. Abbreviations: E, estimated value; M, presence verified but not quantified; $\mu \mathrm{g} / \mathrm{L}$, microgram per liter; dup, duplicate; blank, field blank; <, actual value is less than value shown; ND, not detected; -, not analyzed]

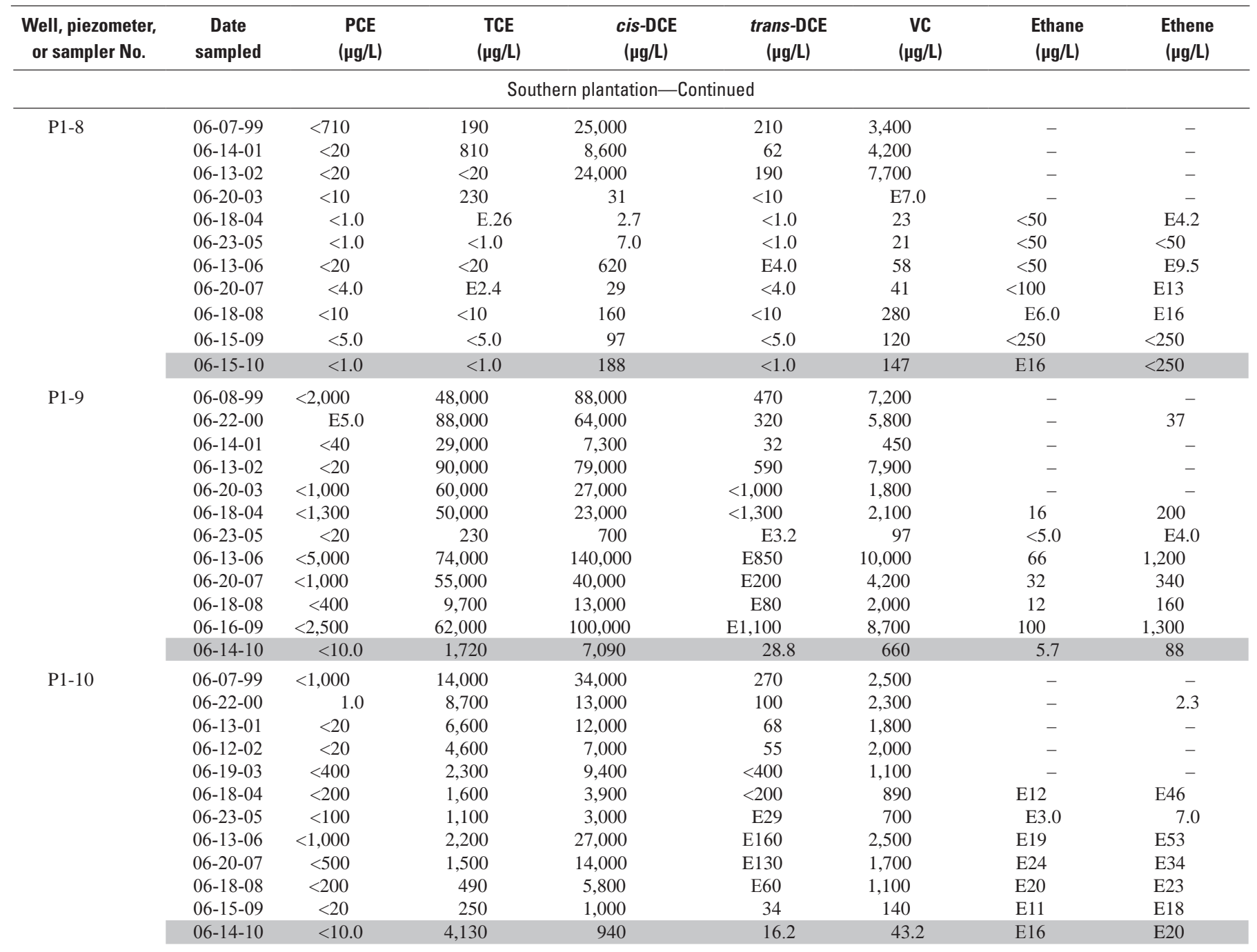


Table 4. Concentrations of selected volatile organic compounds in water samples collected by the U.S. Geological Survey from selected monitoring wells, piezometers, and passive-diffusion samplers at Operable Unit 1, Naval Undersea Warfare Center, Division Keyport, Washington, 1999-2010.-Continued

[All data except those shaded were published previously in Dinicola and others (2002), Dinicola (2003, 2004, 2006), Dinicola and Huffman (2004, 2006, 2007, 2009), and Dinicola and Huffman (2011). Laboratory data qualifier codes, such as "D" for dilution, are not shown. Volatile organic compounds (VOCs); PCE, tetrachloroethene; TCE, trichloroethene; cis-DCE, cis-1,2-dichloroethene; trans-DCE, trans-1,2-dichloroethene; VC, vinyl chloride; 1,1,1-TCA, 1,1,1-trichloroethane; 1,1-DCA, 1,1-dichloroethane; CA, chloroethane; 1,1-DCE, 1,1-dichloroethene; total BTEX, sum of benzene, toluene, ethylbenzene, and xylene; total CVOCs, sum of chlorinated volatile organic compounds. Abbreviations: E, estimated value; M, presence verified but not quantified; $\mu \mathrm{g} / \mathrm{L}$, microgram per liter; dup, duplicate; blank, field blank; <, actual value is less than value shown; ND, not detected; -, not analyzed]

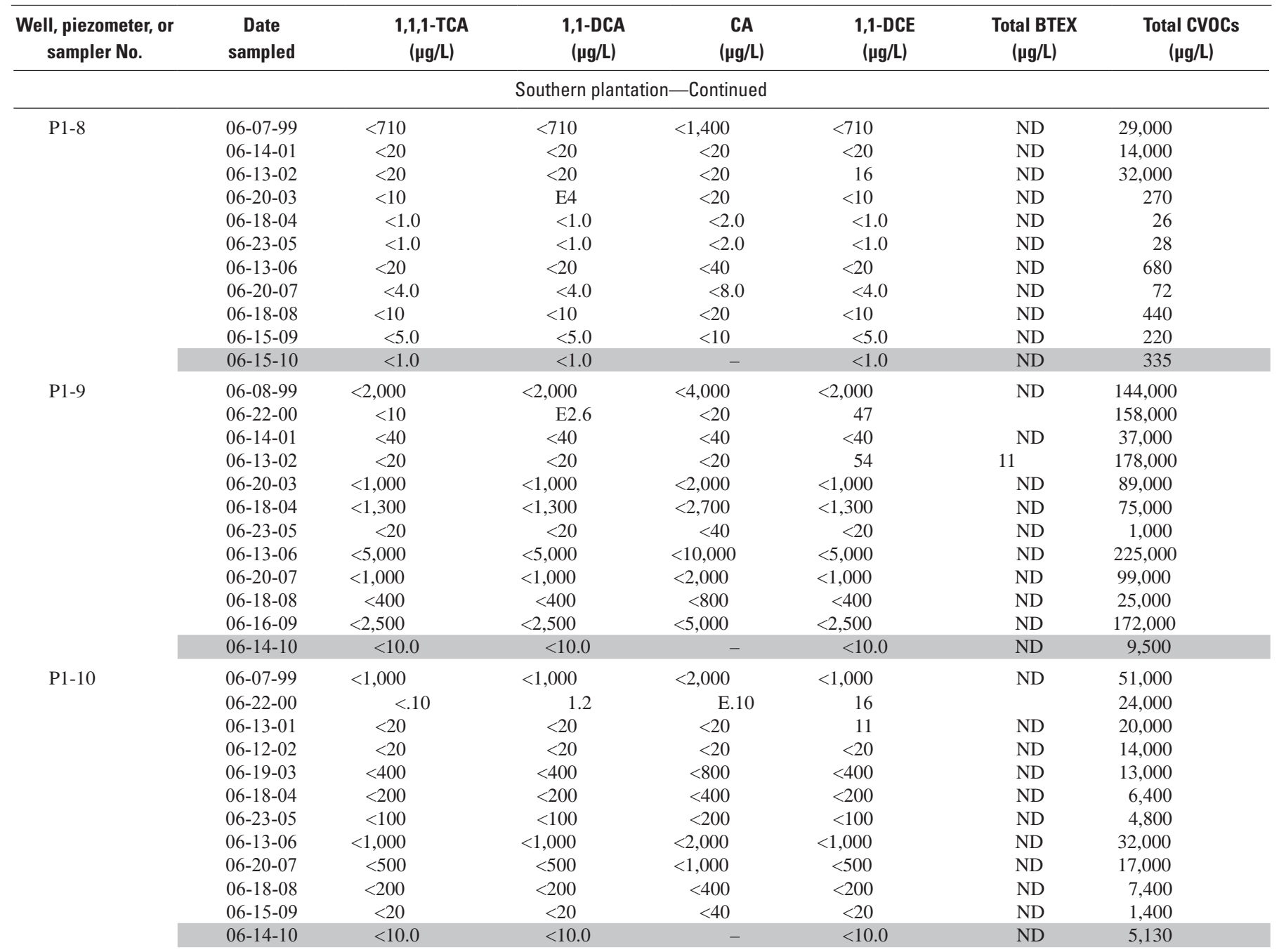


Table 4. Concentrations of selected volatile organic compounds in water samples collected by the U.S. Geological Survey from selected monitoring wells, piezometers, and passive-diffusion samplers at Operable Unit 1, Naval Undersea Warfare Center, Division Keyport, Washington, 1999-2010.-Continued

[All data except those shaded were published previously in Dinicola and others (2002), Dinicola (2003, 2004, 2006), Dinicola and Huffman (2004, 2006, 2007, 2009), and Dinicola and Huffman (2011). Laboratory data qualifier codes, such as "D" for dilution, are not shown. Volatile organic compounds (VOCs); PCE, tetrachloroethene; TCE, trichloroethene; cis-DCE, cis-1,2-dichloroethene; trans-DCE, trans-1,2-dichloroethene; VC, vinyl chloride; 1,1,1-TCA, 1,1,1-trichloroethane; 1,1-DCA, 1,1-dichloroethane; CA, chloroethane; 1,1-DCE, 1,1-dichloroethene; total BTEX, sum of benzene, toluene, ethylbenzene, and xylene; total CVOCs, sum of chlorinated volatile organic compounds. Abbreviations: E, estimated value; M, presence verified but not quantified; $\mu \mathrm{g} / \mathrm{L}$, microgram per liter; dup, duplicate; blank, field blank; <, actual value is less than value shown; ND, not detected; -, not analyzed]

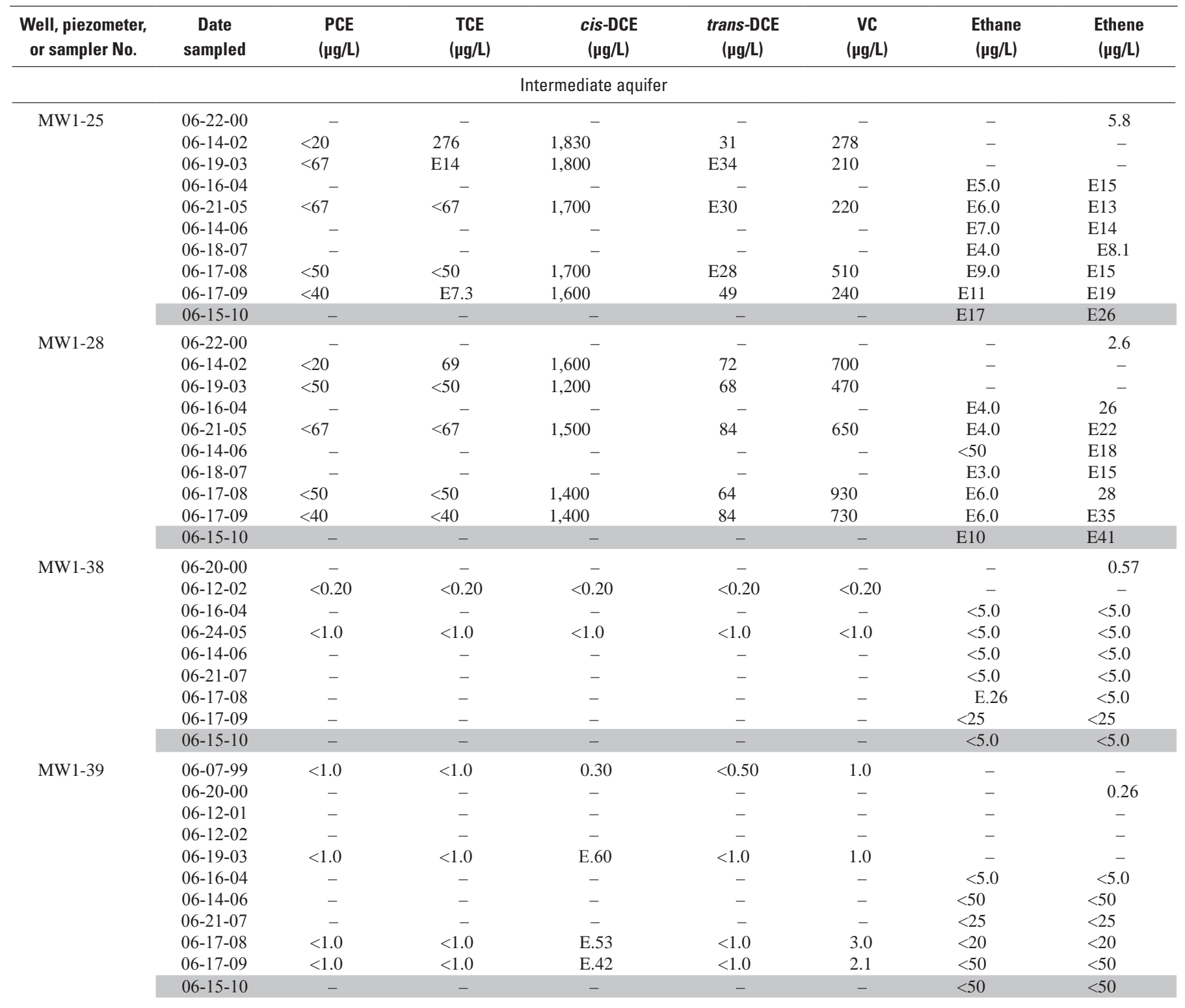


Table 4. Concentrations of selected volatile organic compounds in water samples collected by the U.S. Geological Survey from selected monitoring wells, piezometers, and passive-diffusion samplers at Operable Unit 1, Naval Undersea Warfare Center, Division Keyport, Washington, 1999-2010.-Continued

[All data except those shaded were published previously in Dinicola and others (2002), Dinicola (2003, 2004, 2006), Dinicola and Huffman (2004, 2006, 2007, 2009), and Dinicola and Huffman (2011). Laboratory data qualifier codes, such as "D" for dilution, are not shown. Volatile organic compounds (VOCs); PCE, tetrachloroethene; TCE, trichloroethene; cis-DCE, cis-1,2-dichloroethene; trans-DCE, trans-1,2-dichloroethene; VC, vinyl chloride; 1,1,1-TCA, 1,1,1-trichloroethane; 1,1-DCA, 1,1-dichloroethane; CA, chloroethane; 1,1-DCE, 1,1-dichloroethene; total BTEX, sum of benzene, toluene, ethylbenzene, and xylene; total CVOCs, sum of chlorinated volatile organic compounds. Abbreviations: E, estimated value; M, presence verified but not quantified; $\mu \mathrm{g} / \mathrm{L}$, microgram per liter; dup, duplicate; blank, field blank; <, actual value is less than value shown; ND, not detected; -, not analyzed]

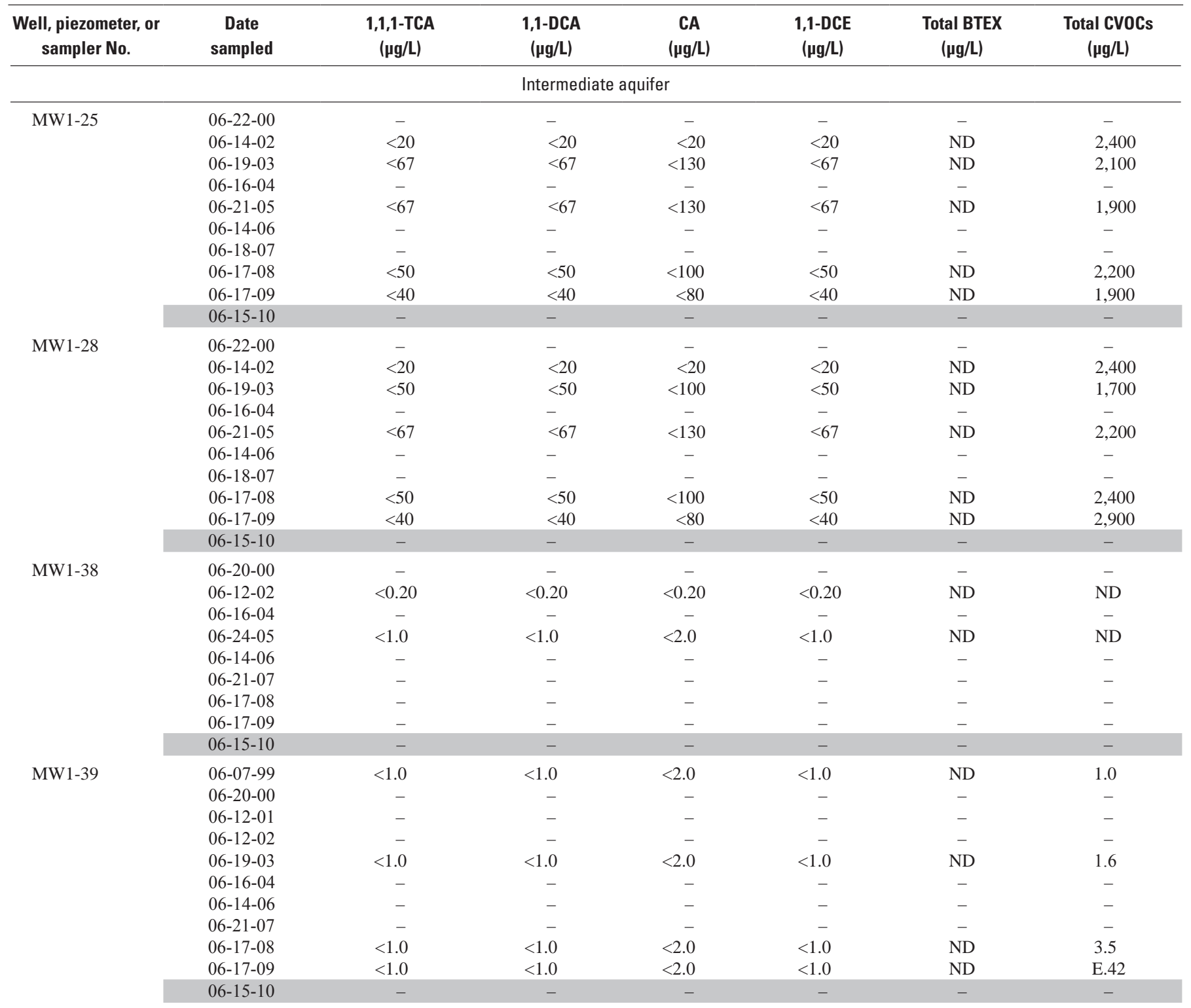


Table 4. Concentrations of selected volatile organic compounds in water samples collected by the U.S. Geological Survey from selected monitoring wells, piezometers, and passive-diffusion samplers at Operable Unit 1, Naval Undersea Warfare Center, Division Keyport, Washington, 1999-2010.-Continued

[All data except those shaded were published previously in Dinicola and others (2002), Dinicola (2003, 2004, 2006), Dinicola and Huffman (2004, 2006, 2007, 2009), and Dinicola and Huffman (2011). Laboratory data qualifier codes, such as "D" for dilution, are not shown. Volatile organic compounds (VOCs); PCE, tetrachloroethene; TCE, trichloroethene; cis-DCE, cis-1,2-dichloroethene; trans-DCE, trans-1,2-dichloroethene; VC, vinyl chloride; 1,1,1-TCA, 1,1,1-trichloroethane; 1,1-DCA, 1,1-dichloroethane; CA, chloroethane; 1,1-DCE, 1,1-dichloroethene; total BTEX, sum of benzene, toluene, ethylbenzene, and xylene; total CVOCs, sum of chlorinated volatile organic compounds. Abbreviations: E, estimated value; M, presence verified but not quantified; $\mu \mathrm{g} / \mathrm{L}$, microgram per liter; dup, duplicate; blank, field blank; <, actual value is less than value shown; ND, not detected; -, not analyzed]

\begin{tabular}{|c|c|c|c|c|c|c|c|c|}
\hline $\begin{array}{c}\text { Well, piezometer, } \\
\text { or sampler No. }\end{array}$ & $\begin{array}{c}\text { Date } \\
\text { sampled }\end{array}$ & $\begin{array}{c}\text { PCE } \\
(\mu \mathrm{g} / \mathrm{L})\end{array}$ & $\begin{array}{c}\text { TCE } \\
\text { ( } \mu \mathrm{g} / \mathrm{L})\end{array}$ & $\begin{array}{c}c i s-D C E \\
(\mu \mathrm{g} / \mathrm{L})\end{array}$ & $\begin{array}{c}\text { trans-DCE } \\
(\mu \mathrm{g} / \mathrm{L})\end{array}$ & $\begin{array}{c}\text { VC } \\
(\mu \mathrm{g} / \mathrm{L})\end{array}$ & $\begin{array}{l}\text { Ethane } \\
(\mu \mathrm{g} / \mathrm{L})\end{array}$ & $\begin{array}{l}\text { Ethene } \\
\text { ( } \mu \mathrm{g} / \mathrm{L} \text { ) }\end{array}$ \\
\hline \multicolumn{9}{|c|}{ Marsh (passive-diffusion samplers) } \\
\hline \multirow{2}{*}{ S1 } & $06-29-05$ & $<1.0$ & 3.5 & 26 & E.83 & 20 & E2.0 & E2.9 \\
\hline & $06-18-10$ & $<.1$ & .7 & 5.3 & .8 & 13 & - & - \\
\hline $\mathrm{S}-2$ & 07-07-00 & $<.1$ & .6 & 11 & 1.3 & 2.8 & - & - \\
\hline \multirow[t]{2}{*}{ S-2B } & $06-29-05$ & $<1.0$ & 4.9 & 34 & 1.1 & 11 & E2.0 & E2.4 \\
\hline & $06-18-10$ & $<.1$ & 1.9 & 26 & 2.2 & 15 & - & - \\
\hline \multirow[t]{3}{*}{ S-3 } & 07-07-00 & $<.1$ & 0.63 & 9.9 & 9.5 & 223 & - & - \\
\hline & $06-29-05$ & $<4.0$ & $<4.0$ & E2.6 & 4.0 & E2.2 & E4 & 88 \\
\hline & 06-18-10 & $<1.0$ & $<1.0$ & 13 & 6.7 & 181 & - & - \\
\hline \multirow{2}{*}{ S-4 } & $06-29-05$ & $<2,000$ & 12,000 & 53,000 & $<2,000$ & 5,300 & 16 & 180 \\
\hline & 06-18-10 & $<.1$ & .1 & 3.9 & .4 & 5.8 & - & - \\
\hline \multirow[t]{2}{*}{ S-4B } & 06-29-05 & $<4.0$ & 120 & 140 & E1.2 & 13 & $<5.0$ & $<5.0$ \\
\hline & 06-18-10 & $<.1$ & .2 & 1 & $<.1$ & $<.2$ & - & - \\
\hline \multirow[t]{4}{*}{ S-5 } & $07-07-00$ & $<.1$ & 49 & 80 & 1.3 & 17.5 & - & - \\
\hline & $07-15-04$ & $<50$ & E16 & 730 & $<50$ & 97 & E0.87 & 12 \\
\hline & $06-29-05$ & $<20$ & 730 & 940 & E7.8 & 60 & $<5.0$ & $<5.0$ \\
\hline & 06-18-10 & $<.1$ & .4 & 1.2 & $<.1$ & .3 & - & - \\
\hline \multirow[t]{2}{*}{ S-5B } & 06-29-05 & $<400$ & 1,200 & 12,000 & E100 & E330 & $<5.0$ & E2.4 \\
\hline & 06-18-10 & $<1.0$ & 4,550 & 3,020 & 146 & 576 & - & - \\
\hline S-6 & $07-07-00$ & $<.1$ & 0.2 & 8.0 & 0.2 & 1.1 & - & - \\
\hline
\end{tabular}


Table 4. Concentrations of selected volatile organic compounds in water samples collected by the U.S. Geological Survey from selected monitoring wells, piezometers, and passive-diffusion samplers at Operable Unit 1, Naval Undersea Warfare Center, Division Keyport, Washington, 1999-2010._-Continued

[All data except those shaded were published previously in Dinicola and others (2002), Dinicola (2003, 2004, 2006), Dinicola and Huffman (2004, 2006, 2007, 2009), and Dinicola and Huffman (2011). Laboratory data qualifier codes, such as "D" for dilution, are not shown. Volatile organic compounds (VOCs); PCE, tetrachloroethene; TCE, trichloroethene; cis-DCE, cis-1,2-dichloroethene; trans-DCE, trans-1,2-dichloroethene; VC, vinyl chloride; 1,1,1-TCA, 1,1,1-trichloroethane; 1,1-DCA, 1,1-dichloroethane; CA, chloroethane; 1,1-DCE, 1,1-dichloroethene; total BTEX, sum of benzene, toluene, ethylbenzene, and xylene; total CVOCs, sum of chlorinated volatile organic compounds. Abbreviations: E, estimated value; M, presence verified but not quantified; $\mu \mathrm{g} / \mathrm{L}$, microgram per liter; dup, duplicate; blank, field blank; <, actual value is less than value shown; ND, not detected; -, not analyzed]

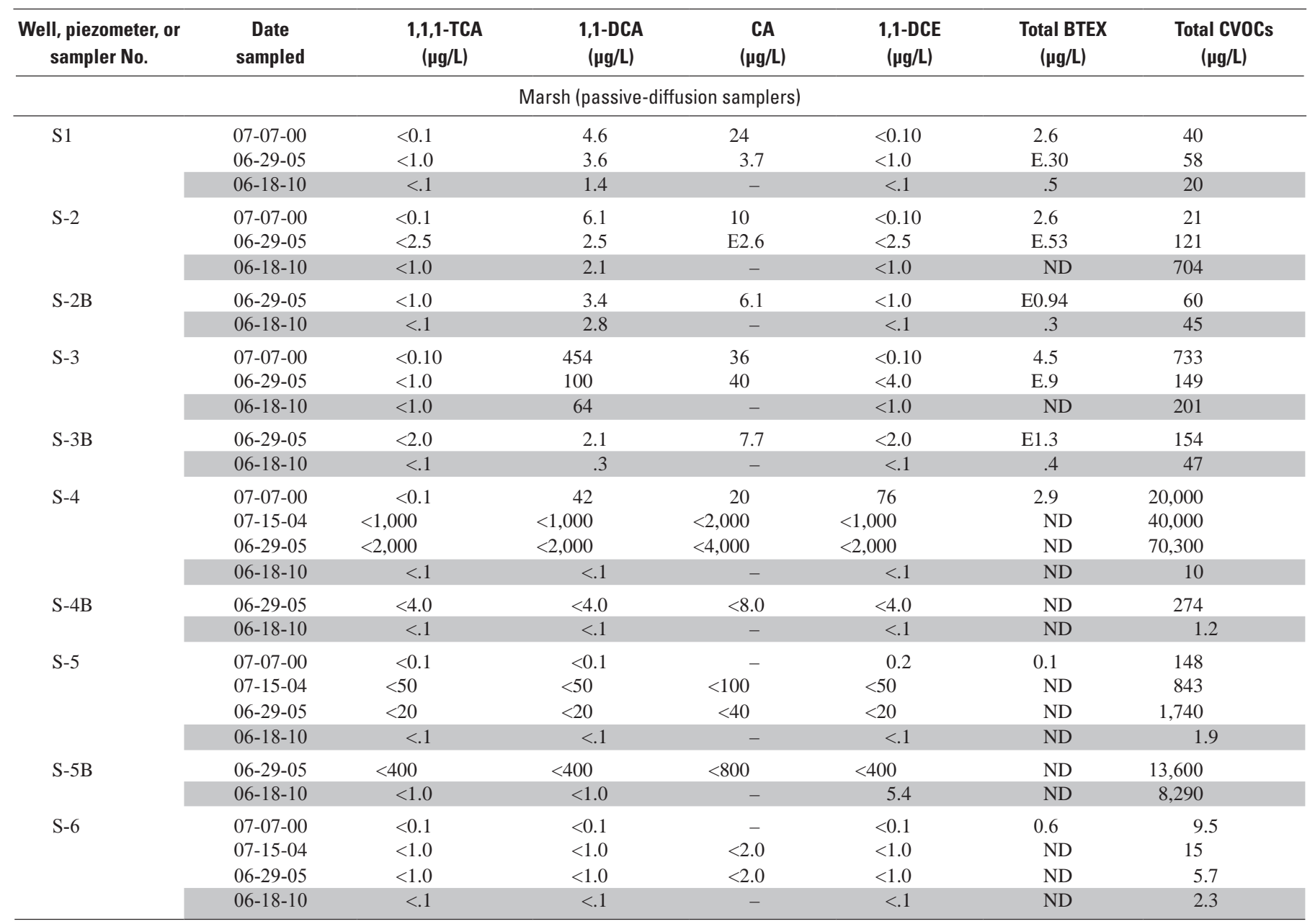


Table 5. Estimated chloroethene mass degradation rates and fluxes to surface water in the southern plantation and adjacent marsh at Operable Unit 1, Naval Undersea Warfare Center, Division Keyport, Washington, 1999-2010.

[All values are in grams per day. Sample sites in "South" landfill sub-transect are MW1-5, P1-6, P1-7,P1-9, MW1-4; sample sites in parallel marsh sub-transect are S-2, S-3,S-4, S-5, S-6 for 1999-2000 and 2004, and sites S-1, S-2, S-2B, S-3, S-3B, S-4, S-4B, S-5, S-5b, S-6 for 2005 and 2010. Abbreviations: TCE, trichloroethene, DCE, cis-1,2-dichloroethene and trans-1,2,dichlorothene; VC, vinyl chloride; <, actual value is less than the value shown]

\begin{tabular}{|c|c|c|c|c|c|c|c|c|c|c|c|c|}
\hline \multirow{2}{*}{$\begin{array}{l}\text { Year chloroethene } \\
\text { data used to } \\
\text { estimate flux }\end{array}$} & \multicolumn{4}{|c|}{$\begin{array}{l}\text { Measured chloroethene } \\
\text { flux at South landfill } \\
\text { sub-tansect }\end{array}$} & \multicolumn{4}{|c|}{$\begin{array}{c}\text { Chloroethene mass degradation } \\
\text { between landfill and } \\
\text { marsh south sub-transect }\end{array}$} & \multicolumn{4}{|c|}{$\begin{array}{l}\text { Chloroethene flux } \\
\text { to surface water }\end{array}$} \\
\hline & TCE & DCE & VC & Total & TCE & DCE & VC & Total & TCE & DCE & VC & Total \\
\hline 1999-2000 & 38 & 37 & 4.2 & 79 & 38 & 61 & 45 & 144 & $<0.1$ & 4.2 & 1.3 & 5.5 \\
\hline 2004 & 32 & 30 & 2.6 & 65 & 32 & 49 & 34 & 115 & $<0.1$ & 5.3 & 3.8 & 9.1 \\
\hline 2005 & 11 & 22 & 2.5 & 36 & 9.1 & 20 & 20 & 49 & 1.7 & 8 & 0.7 & 10 \\
\hline 2010 & 8.2 & 15 & 2.1 & 25 & 7.7 & 20 & 15 & 43 & 0.6 & 0.5 & 0.1 & 1.2 \\
\hline
\end{tabular}




\section{Appendix A. Quality Assurance and Control of U.S. Geological Survey 2010 Geochemical Sampling}

Quality assurance and control of geochemical sampling included collecting duplicate and field blank samples for selected redox-sensitive analytes and volatile organic compounds (VOCs). The field blank was collected by pumping inorganic blank water VOC-free water through new clean tubing to determine possible sampling contamination. Complete laboratory quality assurance and control data from Test America Laboratories is on file with the U.S. Geological Survey Washington Water Science Center in Tacoma, Washington.

Duplicate sample results compared favorably for all constituents (table A1). A duplicate sample was collected for well MW1-17 and piezometer P1-1 and analyzed by the National Water Quality Laboratory (NWQL) for organic carbon, manganese, nitrate plus nitrite, sulfate, and chloride. The relative percent difference of duplicate results for these constituents agreed within 24 percent. Duplicate samples were collected and analyzed for VOCs by the NWQL at piezometers P1-1 and P1-5. No detectable concentrations of CVOCs were in the environmental or duplicate samples. A duplicate sample was collected and analyzed for dissolved gases (methane, ethane, and ethane) by Test America Laboratories for well MW1-17, and piezometer P1-1, and the relative percent difference for these concentrations agreed within 27 percent.

Filtered chloride was detected at an estimated concentrations of $0.11 \mathrm{mg} / \mathrm{L}$ in the blank sample collected at piezometer P1-8, which is small compared to filtered chloride concentrations in environmental samples that were measured at $3.4 \mathrm{mg} / \mathrm{L}$ or higher. Chloroethenes, chloroethanes, and BTEX compounds were not detected in the field blank sample No changes were made to the dataset based on these quality control data.

Table A1. Quality assurance data collected by the U.S. Geological Survey at Operable Unit 1, Naval Undersea Warfare Center, Division Keyport, Washington, June 2010.

[Well or piezometer No.: D denotes duplicate sample; FB denotes field blank sample. Volatile organic compounds (VOCs): PCE, tetrachloroethene; TCE, trichloroethene; cis-DCE, cis-1,2-dichloroethene; trans-DCE, trans-1,2-dichloroethene; VC, vinyl chloride; TCA, 1,1,-trichloroethane; 1,1DCA, 1,1-dichloroethane, CA, chloroethane; 1,1-DCE, 1,1-dichloroethene; BTEX, benzene, toluene, ethylbezene, and xylene; CVOCs, sum of all chloroethenes and chloroethane concentrations shown in table. Abbreviations: $\mu \mathrm{g} / \mathrm{L}$, micrograms per liter; nd, not detected mg/L, milligrams per liter; E, estimated; nd, not detected. Symbols: $<$, actual value is less than the value shown; -, not analyzed]

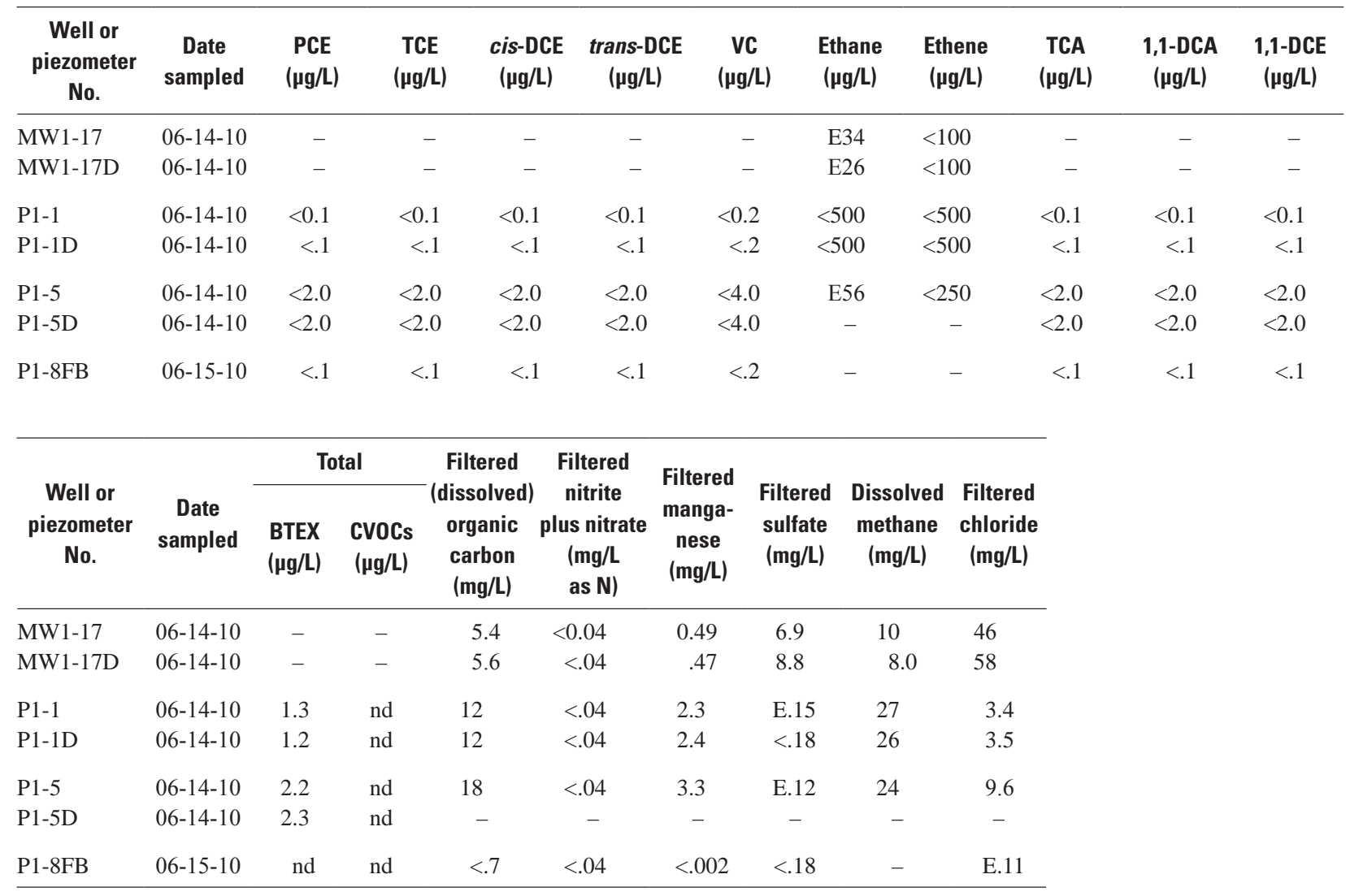


This page intentionally left blank. 
Publishing support provided by the U.S. Geological Survey

Publishing Network, Tacoma Publishing Service Center

For more information concerning the research in this report, contact the Director, Washington Water Science Center

U.S. Geological Survey

934 Broadway, Suite 300

Tacoma, Washington 98402

http://wa.water.usgs.gov 


\section{है}

